\title{
Ligand-Switchable Directing Effects of Tethered Alkenes in Nickel-Catalyzed Additions to Alkynes
}

\author{
Miller, K. M.; Jamison T. F. * \\ Department of Chemistry, Massachusetts Institute of Technology \\ Cambridge, Massachusetts 02139
}

\section{Supporting Information}

\section{General Methods}

Unless otherwise noted, all reactions were performed under an oxygen-free atmosphere of nitrogen or argon with rigid exclusion of moisture from reagents and glassware. Copper iodide, $[(\pi \text {-allyl }) \mathrm{PdCl}]_{2}$, cesium carbonate, bis(cyclooctadienyl)nickel $(0)\left(\mathrm{Ni}(\operatorname{cod})_{2}\right)$, and tricyclopentylphosphine $\left(\mathrm{PCyp}_{3}\right)$ were purchased from Strem Chemicals, Inc. and used without further purification. 1,3-Bis(1-adamantyl)imidazolium chloride was either purchased from Strem Chemicals or prepared on multi-gram scale according to procedures described in the patent literature. ${ }^{1}$ Triethylborane $\left(\mathrm{Et}_{3} \mathrm{~B}, 98 \%\right)$, 3-(bromopropoxy)-tert-butyldimethylsilane, tetrabutylammonium fluoride (1M in THF), oxalyl chloride, triethylamine, methyltriphenylphosphonium bromide, $n$-butyllithium (2.5M in hexanes), 6-bromo-1-hexene, 1-bromopentane, and 4-(dimethylamino)pyridine (DMAP) were purchased from Aldrich Chemical Co. and used as received. 1-Octyne, tetrabutylammmonium iodide, 5-bromo-1-pentene, methanesulfonyl chloride, allylamine, imidazole, tert-butyldimethylsilyl chloride, $p$-toluenesulfonyl chloride, and triphenylphosphine were purchased from Alfa Aesar and used as received. 3-Methyl-1butyne and lithium amide were purchased from GFS Chemicals and used as received. Allyl bromide (Alfa Aesar) and benzyl bromide (Alfa Aesar) were filtered through a plug of silica gel prior to use. Isobutyraldehyde (Alfa Aesar), acetaldehyde (Aldrich), and 3phenylpropionaldehyde (Alfa Aesar) were distilled over anhydrous $\mathrm{MgSO}_{4}$ prior to use. 
(tert-Butyldimethylsilyloxy)acetaldehyde (Aldrich) was distilled prior to use. Tetrahydrofuran and diethyl ether were freshly distilled over blue solutions of sodium/benzophenone ketyl, toluene was freshly distilled over sodium metal, and dichloromethane was distilled over calcium hydride. Ethyl acetate was distilled over anhydrous $\mathrm{MgSO}_{4}$ under argon atmosphere and sparged with argon prior to use. Dimethylformamide (99.9+\%; Aldrich) was dried over activated molecular sieves (3 $\AA$ ) prior to use. Methylsulfoxide (99.9\%; Aldrich) and acetonitrile (99.8\%; Aldrich) were used as received.

Analytical thin layer chromatography (TLC) was performed on silica gel $60 \mathrm{~F}_{254}$ aluminum plates precoated with a fluorescent indicator or EM reagents $0.25 \mathrm{~mm}$ silica gel $60-\mathrm{F}$ plates. Visualization of the developed chromatogram was accomplished with UV light and ethanolic phosphomolybdic acid (PMA) or aqueous potassium permanganate. Liquid chromatography was performed using a forced flow (flash

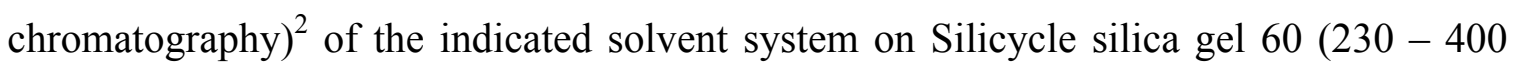
mesh). ${ }^{1} \mathrm{H}$ and ${ }^{13} \mathrm{C}$ NMR spectra were recorded in deuterochloroform $\left(\mathrm{CDCl}_{3}\right)$ on Varian Inova 300 and $500 \mathrm{MHz}$ instruments. Chemical shifts of ${ }^{1} \mathrm{H}$ NMR spectra are reported in parts per million (ppm) on the $\delta$ scale from an internal standard of residual chloroform (7.27 ppm). Data are reported as follows: chemical shift, multiplicity $(\mathrm{s}=$ singlet, $\mathrm{d}=$ doublet, $\mathrm{t}=$ triplet, $\mathrm{q}=$ quartet, $\mathrm{m}=$ multiplet, $\mathrm{b}=$ broad), coupling constant in hertz $(\mathrm{Hz})$, and integration. Chemical shifts of ${ }^{13} \mathrm{C}$ NMR spectra are reported in ppm from the central peak of $\mathrm{CDCl}_{3}(77.23 \mathrm{ppm})$ on the $\delta$ scale. Infrared (IR) spectra were recorded as a thin film between $\mathrm{NaCl}$ plates on a Perkin-Elmer Model 2000 FT-IR System transform spectrometer. High resolution mass spectra (HRMS) were obtained on a Bruker Daltonics APEXII 3 Tesla Fourier Transform Mass Spectrometer by the Massachusetts Institute of Technology Department of Chemistry Instrumentation Facility. GC analysis was performed on a Varian CP-3800 gas chromatograph fitted with Chiraldex B-PH, BDA, and G-TA capillary columns.

\section{Preparation of Starting Materials.}

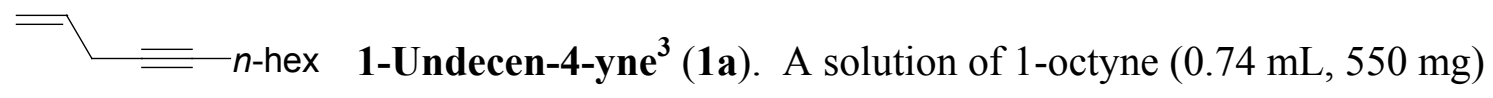


in dimethylformamide was prepared and anhydrous $\mathrm{K}_{2} \mathrm{CO}_{3}(1.04 \mathrm{~g}$, $7.5 \mathrm{mmol})$, copper iodide (95 mg, $0.5 \mathrm{mmol})$, and tetrabutylammonium iodide (1.85 g, $5 \mathrm{mmol})$ were added sequentially. Allyl bromide $(0.56 \mathrm{~mL}, 0.79 \mathrm{~g})$ was added and the mixture stirred overnight. The reaction was diluted with water $(75 \mathrm{~mL})$ and diethyl ether $(75 \mathrm{~mL})$. The organics were extracted twice with diethyl ether $(2 \times 50 \mathrm{~mL})$, rinsed with brine, dried over anhydrous $\mathrm{MgSO}_{4}$, filtered, and concentrated. Flash chromatography on silica gel (hexanes) afforded the title compound as a clear liquid (140 mg, 19\% yield (60\% BRSM)). $\mathrm{R}_{f}=0.40$ (hexanes). Spectral data matches that previously reported. ${ }^{3}{ }^{1} \mathrm{H}$ NMR $\left(500 \mathrm{MHz}, \mathrm{CDCl}_{3}\right) \delta 5.80-5.87(\mathrm{~m}, 1 \mathrm{H}) ; 5.33(\mathrm{dq}, J=17,2 \mathrm{~Hz}, 1 \mathrm{H}) ; 5.10(\mathrm{dq}, J=9.5$, $1.5 \mathrm{~Hz}, 1 \mathrm{H}) ; 2.93-2.97(\mathrm{~m}, 2 \mathrm{H}) ; 2.20(\mathrm{tt}, J=7,2.5 \mathrm{~Hz}, 2 \mathrm{H}) ; 1.48-1.54(\mathrm{~m}, 2 \mathrm{H}) ; 1.24-$ $1.43(\mathrm{~m}, 6 \mathrm{H}) ; 0.90(\mathrm{t}, J=7 \mathrm{~Hz}, 3 \mathrm{H}) .{ }^{13} \mathrm{C} \mathrm{NMR}\left(125 \mathrm{MHz}, \mathrm{CDCl}_{3}\right) \delta 133.62,115.77$, $83.19,76.65,31.60,29.24,28.80,23.53,22.79,19.01,14.29$.

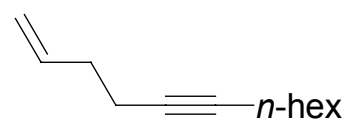

1-Docen-5-yne (1b). According to the procedure described by $\mathrm{Fu}$ and Eckhardt, ${ }^{4}$ in a glove box, 1,3-bis(1-adamantyl)imidazolium chloride (83 mg, $0.23 \mathrm{mmol})$, copper iodide (65 mg, $0.34 \mathrm{mmol}),\left[(\pi \text {-allyl)PdCl }]_{2}(42 \mathrm{mg}\right.$, $0.11 \mathrm{mmol})$, and cesium carbonate $(2.05 \mathrm{~g}, 6.3 \mathrm{mmol})$ were added to a sealed tube equipped with a stir bar. The tube was removed from the glovebox, and diethyl ether (6 $\mathrm{mL})$ was added, followed by dimethylformamide $(3 \mathrm{~mL})$. The tube was placed under argon and 1-octyne $(0.87 \mathrm{~mL}, 5.85 \mathrm{mmol})$ was added, followed by (3-bromopropoxy)tert-butyldimethylsilane $(1.04 \mathrm{~mL}, 4.5 \mathrm{mmol})$. The tube was sealed, placed in a $45^{\circ} \mathrm{C}$ oil bath, and stirred vigorously for $16 \mathrm{~h}$. Once the reaction had cooled it was diluted with diethyl ether $(30 \mathrm{~mL})$ and water $(30 \mathrm{~mL})$. The organics were extracted twice with diethyl ether $(2 \times 30 \mathrm{~mL})$, rinsed with brine, dried over anhydrous $\mathrm{MgSO}_{4}$, and concentrated. Flash chromatography on silica gel (hexanes) provided a brown oil. Kugelrohr distillation $\left(180^{\circ} \mathrm{C}\right.$ at 0.1 Torr) provided tert-butyldimethyl-undec-4-ynyloxy-silane as a clear oil (585 mg, 46\% yield). ${ }^{1} \mathrm{H}$ NMR (500 MHz, $\left.\mathrm{CDCl}_{3}\right) \delta 3.70(\mathrm{t}, J=6 \mathrm{~Hz}, 2 \mathrm{H}) ; 2.23$ $(\mathrm{tt}, J=7,2.5 \mathrm{~Hz}, 2 \mathrm{H}) ; 2.14(\mathrm{tt}, J=7,2.5 \mathrm{~Hz}, 2 \mathrm{H}) ; 1.66-1.72(\mathrm{~m}, 2 \mathrm{H}) ; 1.45-1.51$ (m, $2 \mathrm{H}) ; 1.24-1.41(\mathrm{~m}, 6 \mathrm{H}) ; 0.90(\mathrm{t}, J=7 \mathrm{~Hz}, 3 \mathrm{H}) ; 0.90(\mathrm{~s}, 9 \mathrm{H}) ; 0.06(\mathrm{~s}, 6 \mathrm{H})$. 
tert-Butyldimethyl-undec-4-ynyloxy-silane (500 $\mathrm{mg}, 1.77 \mathrm{mmol}$ ) was dissolved in THF $(18 \mathrm{~mL})$ and the solution was cooled to $0^{\circ} \mathrm{C}$. Tetrabutylammonium fluoride $(2.12$ $\mathrm{mL}$ of $1 \mathrm{M}$ solution in THF) was added, and the mixture was stirred for one hour at $0{ }^{\circ} \mathrm{C}$ and an additional 45 minutes at room temperature. Brine was added, and the organics were then extracted with ethyl acetate $(3 \times 30 \mathrm{~mL})$, dried over anhydrous $\mathrm{MgSO}_{4}$, filtered and concentrated. Flash chromatography on silica gel (5:1 hexanes: ethyl acetate) provided undec-4-yn-1-ol as a clear oil (200 mg, 67\% yield). ${ }^{1} \mathrm{H}$ NMR (500 MHz, $\left.\mathrm{CDCl}_{3}\right) \delta 3.77$ (t, $\left.J=6 \mathrm{~Hz}, 2 \mathrm{H}\right) ; 2.29$ (tt, $\left.J=6.5,2.5 \mathrm{~Hz}, 2 \mathrm{H}\right) ; 2.14$ (tt, $J=7,2.5 \mathrm{~Hz}, 2 \mathrm{H}$ ); $1.72-1.77$ (m, 2H); 1.61 (bs, 1H); $1.44-1.52$ (m, 2H); $1.24-1.40$ (m, 6H); 0.89 (t, $J=$ $7 \mathrm{~Hz}, 3 \mathrm{H})$.

Dichloromethane $(12 \mathrm{~mL})$ was added to oxalyl chloride $(158 \mu \mathrm{L}, 1.79 \mathrm{mmol})$ and the mixture was cooled to $-78{ }^{\circ} \mathrm{C}$. Methylsulfoxide $(169 \mu \mathrm{L}, 2.38 \mathrm{mmol})$ was added, followed by a solution of undec-4-yn-1-ol $(200 \mathrm{mg}, 1.19 \mathrm{mmol})$ in dichloromethane (4 $\mathrm{mL})$. The reaction was stirred for 20 minutes at $-78^{\circ} \mathrm{C}$, and then triethylamine $(500 \mathrm{~mL}$, $3.57 \mathrm{mmol}$ ) was added. The reaction was warmed to $0{ }^{\circ} \mathrm{C}$ and stirred for 30 minutes. The mixture was washed twice with water $(2 \times 25 \mathrm{~mL})$, and then the organics were extraced with dichloromethane $(2 \times 30 \mathrm{~mL})$, dried over anhydrous $\mathrm{MgSO}_{4}$, filtered, and concentrated. The crude aldehyde was used immediately in the subsequent step.

A solution of methyltriphenylphosphonium bromide (429 mg, $1.2 \mathrm{mmol}$ ) in THF $(5 \mathrm{~mL})$ was cooled to $0{ }^{\circ} \mathrm{C}$ and $n$ - $\mathrm{BuLi}(0.48 \mathrm{~mL}$ of a $2.5 \mathrm{M}$ solution in hexanes) was added. After stirring for 30 minutes at $0{ }^{\circ} \mathrm{C}$, the mixture was cooled to $-78{ }^{\circ} \mathrm{C}$, and a solution of the aldehyde in THF $(1.5 \mathrm{~mL})$ was added. The reaction was stirred for 15 minutes and then warmed to ambient temperature. A saturated aqueous solution of $\mathrm{NH}_{4} \mathrm{Cl}(10 \mathrm{~mL})$ was added, and the organics were extracted with diethyl ether $(2 \times 20$ $\mathrm{mL}$ ). The organic layer was dried over anhydrous $\mathrm{MgSO}_{4}$, filtered, and concentrated. Flash chromatography on silica gel (hexanes) afforded the title compound as a clear oil (137 mg, 70\% yield over two steps). $\mathrm{R}_{f}=0.30$ (hexanes). Spectral data matches that previously reported. ${ }^{5}{ }^{1} \mathrm{H}$ NMR $\left(500 \mathrm{MHz}, \mathrm{CDCl}_{3}\right) \delta 5.83-5.91(\mathrm{~m}, 1 \mathrm{H}) ; 5.05-5.09(\mathrm{~m}$, $1 \mathrm{H}) ; 5.00-5.03(\mathrm{~m}, 1 \mathrm{H}) ; 2.23-2.26(\mathrm{~m}, 4 \mathrm{H}) ; 2.13-2.17(\mathrm{~m}, 2 \mathrm{H}) ; 1.44-1.51(\mathrm{~m}, 2 \mathrm{H})$; $1.24-1.41(\mathrm{~m}, 6 \mathrm{H}) ; 0.90$ (t, $J=7 \mathrm{~Hz}, 3 \mathrm{H}) .{ }^{13} \mathrm{C} \mathrm{NMR}\left(125 \mathrm{MHz}, \mathrm{CDCl}_{3}\right) \delta 137.53$, $115.54,81.01,79.58,33.62,31.60,29.30,28.75,22.80,18.95,18.87,14.29$. 


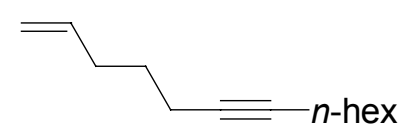

1-Tridecen-6-yne (1c). According to the procedure described by $\mathrm{Fu}$ and Eckhardt, ${ }^{4}$ in a glove box, 1,3-bis(1-

adamantyl)imidazolium chloride $(370 \mathrm{mg}, 1.0 \mathrm{mmol})$, copper iodide (290 mg, $1.5 \mathrm{mmol})$, $[(\pi \text {-allyl }) \mathrm{PdCl}]_{2}(185 \mathrm{mg}, 0.5 \mathrm{mmol})$, and cesium carbonate $(9.1 \mathrm{~g}, 28 \mathrm{mmol})$ were added to a sealed tube equipped with a stir bar. The tube was removed from the glovebox, and diethyl ether $(28 \mathrm{~mL})$ was added, followed by dimethylformamide $(14 \mathrm{~mL})$. The tube was placed under argon and 1-octyne $(3.85 \mathrm{~mL}, 26 \mathrm{mmol})$ was added, followed by 5 bromo-1-pentene $(2.35 \mathrm{~mL}, 20 \mathrm{mmol})$. The tube was sealed, placed in a $45^{\circ} \mathrm{C}$ oil bath, and stirred vigorously for $16 \mathrm{~h}$. Once the reaction had cooled it was diluted with diethyl ether $(100 \mathrm{~mL})$ and water $(100 \mathrm{~mL})$. The organics were extracted twice with diethyl ether $(2 \times 100 \mathrm{~mL})$, rinsed with brine, dried over anhydrous $\mathrm{MgSO}_{4}$, and concentrated. Flash chromatography on silica gel yielded an orange oil. Kugelrohr distillation $\left(125^{\circ} \mathrm{C}\right.$ at 20 Torr) afforded the title compound as a clear oil (2.03 g, 57\% yield). $\mathrm{R}_{f}=0.57$ (hexanes). Spectral data matches that previously reported. ${ }^{6}{ }^{1} \mathrm{H} \mathrm{NMR}\left(500 \mathrm{MHz}, \mathrm{CDCl}_{3}\right)$ $\delta 5.76-5.85(\mathrm{~m}, 1 \mathrm{H}) ; 5.01-5.06(\mathrm{~m}, 1 \mathrm{H}) ; 4.96-4.99(\mathrm{~m}, 1 \mathrm{H}) ; 2.12-2.19(\mathrm{~m}, 6 \mathrm{H})$; 1.58 (quin., $J=7 \mathrm{~Hz}, 2 \mathrm{H}$ ); 1.48 (quin., $J=7 \mathrm{~Hz}, 2 \mathrm{H}) ; 1.24-1.42$ (m, 6H); 0.90 (t, $J=$ 7Hz, 3H). ${ }^{13} \mathrm{C} \mathrm{NMR}\left(125 \mathrm{MHz}, \mathrm{CDCl}_{3}\right) \delta 138.36,115.14,80.83,79.96,33.04,31.60$, $29.34,28.77,28.54,22.81,18.98,18.41,14.30$.

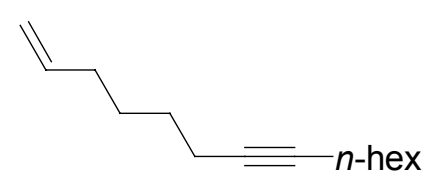

1-Tetradecen-7-yne (1d). According to the procedure described by $\mathrm{Fu}$ and Eckhardt, ${ }^{4}$ in a glove box, 1,3-bis(1adamantyl)imidazolium chloride (95 $\mathrm{mg}, 0.25 \mathrm{mmol}$ ), copper iodide (74 $\mathrm{mg}, 0.38 \mathrm{mmol}),\left[(\pi \text {-allyl)PdCl}]_{2}(47 \mathrm{mg}, 0.13 \mathrm{mmol})\right.$, and cesium carbonate $(2.30 \mathrm{~g}, 7.00 \mathrm{mmol})$ were added to a sealed tube equipped with a stir bar. The tube was removed from the glovebox, and diethyl ether $(6.7 \mathrm{~mL})$ was added, followed by dimethylformamide $(3.3 \mathrm{~mL})$. The tube was placed under argon and 1-octyne $(0.96 \mathrm{~mL}$, $6.5 \mathrm{mmol})$ was added, followed by 6-bromo-1-hexene $(0.67 \mathrm{~mL}, 5 \mathrm{mmol})$. The tube was sealed, placed in a $45^{\circ} \mathrm{C}$ oil bath, and stirred vigorously for $16 \mathrm{~h}$. Once the reaction had cooled it was diluted with diethyl ether $(25 \mathrm{~mL})$ and water $(25 \mathrm{~mL})$. The organics were extracted twice with diethyl ether $(2 \times 25 \mathrm{~mL})$, rinsed with brine, dried over anhydrous 
$\mathrm{MgSO}_{4}$, and concentrated. Flash chromatography on silica gel (hexanes) afforded the title compound as a clear oil (72 $\mathrm{mg}, 10 \%$ yield). $\mathrm{R}_{f}=0.40$ (hexanes). Spectral data matches that previously reported. ${ }^{7}{ }^{1} \mathrm{H}$ NMR $\left(500 \mathrm{MHz}, \mathrm{CDCl}_{3}\right) \delta 5.77-5.88(\mathrm{~m}, 1 \mathrm{H})$; 4.99 - 5.04 (m, 1H); 4.93 - 4.97 (m, 1H); 2.12 - 2.19 (m, 4H); $2.04-2.10$ (m, 2H); 1.24 - $1.56(\mathrm{~m}, 12 \mathrm{H}) ; 0.90(\mathrm{t}, J=7 \mathrm{~Hz}, 3 \mathrm{H}) .{ }^{13} \mathrm{C} \mathrm{NMR}\left(125 \mathrm{MHz}, \mathrm{CDCl}_{3}\right) \delta 139.00,114.64$, $80.63,80.18,33.52,31.60,29.34,28.80,28.77,28.26,22.80,18.98,18.83,14.29$.

$n$-pentyl $=n$-hexyl 6-Tridecyne (4). According to the procedure described by $\mathrm{Fu}$ and Eckhardt, ${ }^{4}$ in a glove box, 1,3-bis(1-adamantyl)imidazolium chloride (95 mg, 0.25 mmol), copper iodide (74 mg, $0.38 \mathrm{mmol}),\left[(\pi \text {-allyl)PdCl }]_{2}(47 \mathrm{mg}, 0.13 \mathrm{mmol})\right.$, and cesium carbonate $(2.30 \mathrm{~g}, 7.00 \mathrm{mmol})$ were added to a sealed tube equipped with a stir bar. The tube was removed from the glovebox, and diethyl ether $(6.7 \mathrm{~mL})$ was added, followed by dimethylformamide $(3.3 \mathrm{~mL})$. The tube was placed under argon and 1octyne $(0.96 \mathrm{~mL}, 6.5 \mathrm{mmol})$ was added, followed by 1-bromopentane $(0.62 \mathrm{~mL}, 5 \mathrm{mmol})$. The tube was sealed, placed in a $45^{\circ} \mathrm{C}$ oil bath, and stirred vigorously for $16 \mathrm{~h}$. Once the reaction had cooled it was diluted with diethyl ether $(25 \mathrm{~mL})$ and water $(25 \mathrm{~mL})$. The organics were extracted twice with diethyl ether $(2 \times 25 \mathrm{~mL})$, rinsed with brine, dried over anhydrous $\mathrm{MgSO}_{4}$, and concentrated. Flash chromatography on silica gel (hexanes) yielded an orange oil. Kugelrohr distillation $\left(120^{\circ} \mathrm{C}\right.$ at 20 Torr $)$ afforded the title compound as a clear oil (372 $\mathrm{mg}, 41 \%$ yield). $\mathrm{R}_{f}=0.66$ (hexanes). Spectral data matches that previously reported. ${ }^{8}{ }^{1} \mathrm{H}$ NMR $\left(500 \mathrm{MHz}, \mathrm{CDCl}_{3}\right) \delta 2.12-2.17(\mathrm{~m}, 4 \mathrm{H})$; $1.44-1.52(\mathrm{~m}, 4 \mathrm{H}) ; 1.24-1.41(\mathrm{~m}, 10 \mathrm{H}) ; 0.90(\mathrm{t}, J=7 \mathrm{~Hz}, 3 \mathrm{H}) ; 0.90(\mathrm{t}, J=7 \mathrm{~Hz}, 3 \mathrm{H})$. ${ }^{13} \mathrm{C}$ NMR $\left(125 \mathrm{MHz}, \mathrm{CDCl}_{3}\right) \delta 80.46,80.45,31.60,31.30,29.36,29.09,28.76,22.80$, $22.46,18.98,18.95,14.29,14.24$.

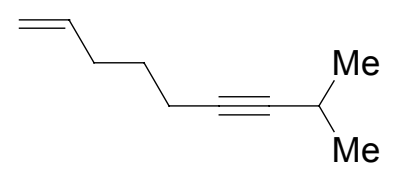

8-Methyl-non-1-en-6-yne (1e). According to the procedure described by Fu and Eckhardt, ${ }^{4}$ in a glove box, 1,3-bis(1adamantyl)imidazolium chloride (380 mg, $1.0 \mathrm{mmol})$, copper iodide (296 mg, $1.5 \mathrm{mmol}),[(\pi \text {-allyl }) \mathrm{PdCl}]_{2}(188 \mathrm{mg}, 0.5 \mathrm{mmol})$, and cesium carbonate (4.6 g, $14 \mathrm{mmol}$ ) were added to a sealed tube equipped with a stir bar. The tube was removed from the glovebox, and diethyl ether $(13 \mathrm{~mL})$ was added, followed by 
dimethylformamide $(6.5 \mathrm{~mL})$. The tube was placed under argon and 3-methyl-1-butyne (2.0 mL, $20 \mathrm{mmol})$ was added, followed by 5-bromo-1-pentene $(1.18 \mathrm{~mL}, 10 \mathrm{mmol})$.

The tube was sealed, placed in a $45^{\circ} \mathrm{C}$ oil bath, and stirred vigorously for $16 \mathrm{~h}$. Once the reaction had cooled it was diluted with diethyl ether $(50 \mathrm{~mL})$ and water $(50 \mathrm{~mL})$. The organics were extracted twice with diethyl ether $(2 \times 50 \mathrm{~mL})$, rinsed with brine, dried over anhydrous $\mathrm{MgSO}_{4}$, and concentrated. Flash chromatography on silica gel (hexanes) provided an orange oil. Kugelrohr distillation $\left(115^{\circ} \mathrm{C}\right.$ at 20 Torr $)$ afforded the title compound as a clear oil (656 mg, 48\% yield). $\mathrm{R}_{f}=0.52$ (hexanes). ${ }^{1} \mathrm{H} \mathrm{NMR}(500 \mathrm{MHz}$, $\left.\mathrm{CDCl}_{3}\right) \delta 5.77-5.85(\mathrm{~m}, 1 \mathrm{H}) ; 5.01-5.06(\mathrm{~m}, 1 \mathrm{H}) ; 4.96-4.99(\mathrm{~m}, 1 \mathrm{H}) ; 2.48-2.58(\mathrm{~m}$, $1 \mathrm{H}) ; 2.12-2.19(\mathrm{~m}, 4 \mathrm{H}) ; 1.54-1.61(\mathrm{~m}, 2 \mathrm{H}) ; 1.15(\mathrm{~d}, J=7 \mathrm{~Hz}, 6 \mathrm{H}) .{ }^{13} \mathrm{C} \mathrm{NMR}(125$ $\left.\mathrm{MHz}, \mathrm{CDCl}_{3}\right) \delta 138.38,115.12,86.61,79.10,33.00,28.53,26.82,23.67,20.74,18.33$. IR (thin film NaCl): 3079, 2971, 2936, 1642, 1465, 1362, 1321, 1257, 1154, 992, 913.

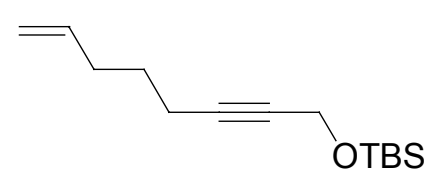

tert-Butyl-dimethyl-oct-7-en-2-ynyloxy-silane (1f). Lithium amide (604 mg, $26 \mathrm{mmol}$ ) was added under argon atmosphere to a $250 \mathrm{~mL}$ three-necked, round-bottom flask that had been fitted with a dry ice condenser, a mechanical stirrer, and an addition funnel. The flask was cooled to $-78{ }^{\circ} \mathrm{C}$ and liquid ammonia $(25 \mathrm{~mL})$ was added. The mixture was then stirred, and tert-butyldimethyl(prop-2-ynyloxy) silane ${ }^{9}$ (4.26 g, $25 \mathrm{mmol}$ ) was added dropwise over 10 minutes via the addition funnel. After stirring at $-78^{\circ} \mathrm{C}$ for $1 \mathrm{~h}, 5$ bromo-1-pentene $(2.96 \mathrm{~mL}, 25 \mathrm{mmol})$ was added dropwise over 10 minutes via the addition funnel. After $2 \mathrm{~h}$ at $-78^{\circ} \mathrm{C}$, no conversion was observed, so the reaction was allowed to warm to $-40{ }^{\circ} \mathrm{C}$ and stir for an additional $2 \mathrm{~h}$. The reaction was quenched by addition of water $(50 \mathrm{~mL})$, diluted with diethyl ether $(50 \mathrm{~mL})$, and allowed to warm to ambient temperature overnight. Organics were then extracted with additional diethyl ether $(2 \times 50 \mathrm{~mL})$, rinsed with brine $(100 \mathrm{~mL})$, dried and concentrated. Crude NMR revealed a 3:1 mixture of starting alkyne:1g. Distillation of the mixture $\left(70{ }^{\circ} \mathrm{C}\right.$ at 0.1 Torr) afforded the title compound as a clear oil ( $800 \mathrm{mg}, 15 \%$ yield). $\mathrm{R}_{f}=0.20$ (hexanes). ${ }^{1} \mathrm{H}$ NMR (500 MHz, $\left.\mathrm{CDCl}_{3}\right) \delta 5.76$ (m, 1H); 5.04 (dq, $\left.J=17,2 \mathrm{~Hz}, 1 \mathrm{H}\right) ; 4.98$ (d of quintets, $J=10,1 \mathrm{~Hz}, 1 \mathrm{H}) ; 4.31$ (t, $J=2 \mathrm{~Hz}, 2 \mathrm{H}) ; 2.23(\mathrm{tt}, J=7,2 \mathrm{~Hz}, 1 \mathrm{H}) ; 2.13$ $2.18(\mathrm{~m}, 2 \mathrm{H}) ; 1.61$ (quin., $J=7 \mathrm{~Hz}, 2 \mathrm{H}) ; 0.92(\mathrm{~s}, 9 \mathrm{H}) ; 0.13(\mathrm{~s}, 6 \mathrm{H}) .{ }^{13} \mathrm{C} \mathrm{NMR}(125 \mathrm{MHz}$, 
$\left.\mathrm{CDCl}_{3}\right) \delta 138.11,115.33,85.24,79.12,52.21,33.01,27.98,26.24,26.08,18.39,-4.89$. IR (thin film NaCl): 3079, 2931, 2898, 2858, 1642, 1473, 1463, 1390, 1362, 1254, 1140 , 1082. HRMS (ESI) $m / z 261.164$ [(M+Na) ${ }^{+}$; calcd for $\mathrm{C}_{14} \mathrm{H}_{26} \mathrm{OSi}$ : 261.165].

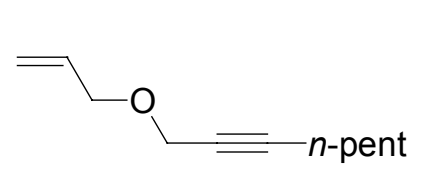

1-Allyloxy-oct-2-yne ${ }^{\mathbf{1 0}} \mathbf{( 1 g )}$. NaH (456 mg of a $57 \%$ dispersion in mineral oil, $11 \mathrm{mmol}$ ) was suspended in THF (5 $\mathrm{mL})$ and 2-octyn-1-ol (0.87 mL, $10 \mathrm{mmol})$ in THF $(2.5 \mathrm{~mL})$ was added dropwise via syringe. The mixture was stirred for 30 minutes at ambient temperature, and then allyl bromide $(1.04 \mathrm{~mL}, 12 \mathrm{mmol})$ was added. The mixture was stirred for $3 \mathrm{~h}$ at ambient temperature, at which point water $(25 \mathrm{~mL})$ and diethyl ether $(25$ $\mathrm{mL}$ ) were added. The organic layer was collected, dried over anhydrous $\mathrm{MgSO}_{4}$, and concentrated. Subsequent purification via flash chromatography on silica gel afforded the title compound as a clear liquid ( $650 \mathrm{mg}, 39 \%$ yield). $\mathrm{R}_{f}=0.52$ (10:1 hexanes: ethyl acetate). Spectral data matches that previously reported. ${ }^{10}{ }^{1} \mathrm{H} \mathrm{NMR}\left(500 \mathrm{MHz}, \mathrm{CDCl}_{3}\right)$ $\delta 5.89-5.97(\mathrm{~m}, 1 \mathrm{H}) ; 5.29-5.33(\mathrm{~m}, 1 \mathrm{H}) ; 5.20-5.23(\mathrm{~m}, 1 \mathrm{H}) ; 4.15(\mathrm{t}, J=2 \mathrm{~Hz}, 2 \mathrm{H})$; $4.04-4.07$ (m, 2H); 2.22 (tt, $J=7,2 \mathrm{~Hz}, 2 \mathrm{H}) ; 1.49-1.56$ (m, 2H); $1.24-1.40$ (m, 4H); $0.90(\mathrm{t}, J=7 \mathrm{~Hz}, 3 \mathrm{H}) .{ }^{13} \mathrm{C} \mathrm{NMR}\left(125 \mathrm{MHz}, \mathrm{CDCl}_{3}\right) \delta 134.43,117.87,87.37,75.95$, $70.63,57.96,31.25,28.52,22.40,18.95,14.19$.

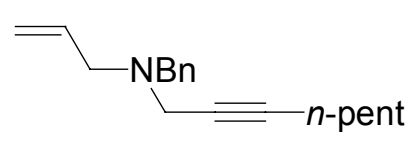

Allyl-benzyl-oct-2-ynyl-amine (1h). A solution of 2-octyn-1ol $(1.73 \mathrm{~mL}, 20 \mathrm{mmol})$ and triethylamine $(3.35 \mathrm{~mL}, 24 \mathrm{mmol})$ in diethyl ether $(40 \mathrm{~mL})$ was prepared and cooled to $0{ }^{\circ} \mathrm{C}$.

Methanesulfonyl chloride $(1.70 \mathrm{~mL}, 22 \mathrm{mmol})$ was then added dropwise, and the mixture was stirred at $0{ }^{\circ} \mathrm{C}$ for $20 \mathrm{~min}$. Water $(50 \mathrm{~mL}), 1 \mathrm{M} \mathrm{HCl}(10 \mathrm{~mL})$, and additional diethyl ether $(25 \mathrm{~mL})$ were added. The organic layer was then washed sequentially with saturated solutions of $\mathrm{NaHCO}_{3}(50 \mathrm{~mL})$ and $\mathrm{NaCl}(50 \mathrm{~mL})$. The organic layer was dried, concentrated, and then added to neat allylamine $(7.5 \mathrm{~mL}, 100 \mathrm{mmol})$ at $0{ }^{\circ} \mathrm{C}$. The mixture was allowed to warm gradually to ambient temperature and stirred for $1.5 \mathrm{~h}$. The reaction was then poured into diethyl ether $(75 \mathrm{~mL})$ and the resulting white solid was removed via filtration. The filtrate was concentrated and distilled $\left(175^{\circ} \mathrm{C}, 15\right.$ Torr $)$ to provide allyl-oct-2-ynyl-amine as a clear liquid ( $1.42 \mathrm{~g}, 44 \%$ yield). 
Allyl-oct-2-ynyl-amine $(1.13 \mathrm{~g}, 6.84 \mathrm{mmol})$ was dissolved in acetonitrile $(30 \mathrm{~mL})$, and then anhydrous $\mathrm{K}_{2} \mathrm{CO}_{3}(1.89 \mathrm{~g}, 13.68 \mathrm{mmol})$ and benzyl bromide $(0.98 \mathrm{~mL}, 8.21$ mmol) were added. The mixture was stirred vigorously overnight. The solvent was removed in vacuo and the residue was dissolved in water $(75 \mathrm{~mL})$ and diethyl ether $(75$ $\mathrm{mL}$ ). The organic layer was collected, rinsed with brine, dried, and concentrated. Subsequent purification via flash chromatography on silica gel (10:1 hexanes:ethyl acetate) afforded the title compound as a clear liquid ( $0.95 \mathrm{~g}, 54 \%$ yield). $\mathrm{R}_{f}=0.60$ (10:1 hexanes: ethyl acetate). ${ }^{1} \mathrm{H} \mathrm{NMR}\left(500 \mathrm{MHz}, \mathrm{CDCl}_{3}\right) \delta 7.24-7.38(\mathrm{~m}, 5 \mathrm{H}) ; 5.86-5.94$ $(\mathrm{m}, 1 \mathrm{H}) ; 5.25-5.30(\mathrm{~m}, 1 \mathrm{H}) ; 5.15-5.18(\mathrm{~m}, 1 \mathrm{H}) ; 3.64(\mathrm{~s}, 2 \mathrm{H}) ; 3.28(\mathrm{t}, J=2 \mathrm{~Hz}, 2 \mathrm{H})$; $3.17(\mathrm{~d}, J=6.5 \mathrm{~Hz}, 2 \mathrm{H}) ; 2.25(\mathrm{dt}, J=7,2 \mathrm{~Hz}, 2 \mathrm{H}) ; 1.53-1.59(\mathrm{~m}, 2 \mathrm{H}) ; 1.32-1.46$ (m, $4 \mathrm{H}) ; 0.93(\mathrm{t}, J=7 \mathrm{~Hz}, 3 \mathrm{H}) .{ }^{13} \mathrm{C} \mathrm{NMR}\left(125 \mathrm{MHz}, \mathrm{CDCl}_{3}\right) \delta 135.99,129.44,128.44$, 127.25, 118.06, 100.00, 86.06, 74.53, 57.39, 56.86, 41.98, 31.32, 28.95, 22.44, 18.92, 14.28. IR (thin film NaCl): 3065, 3029, 2957, 2931, 2860, 2815, 1643, 1495, 1455, $1432,1368,1327,1253,1117$. HRMS (ESI) $m / z 256.206\left[(\mathrm{M}+\mathrm{H})^{+}\right.$; calcd for $\mathrm{C}_{18} \mathrm{H}_{25} \mathrm{~N}$ : 256.206].

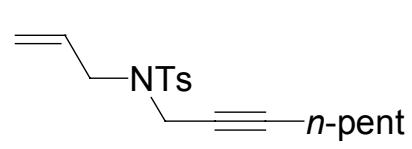

$N$-allyl- $N$-oct-2-ynyl-benzenesulfonamide (1i). Allyl-oct-2ynyl-amine (1.013 g, $6.13 \mathrm{mmol})$ (see above entry for preparation) was dissolved in dichloromethane $(7.5 \mathrm{~mL})$ and triethylamine $(1.28 \mathrm{~mL}, 9.15 \mathrm{mmol})$ was added. The solution was cooled to $0{ }^{\circ} \mathrm{C}$ and a solution of $p$-toluenesulfonyl chloride $(1.40 \mathrm{~g}, 7.32 \mathrm{mmol})$ in dichloromethane $(5.0 \mathrm{~mL})$ was added. The mixture was allowed to warm to ambient temperature and stirred for $1 \mathrm{~h}$. The reaction was quenched with phosphate buffer $(\mathrm{pH} 7)$, and the organics were extracted with additional dichloromethane $(2 \times 25 \mathrm{~mL})$, washed with brine, dried over anhydrous $\mathrm{MgSO}_{4}$, and concentrated. Subsequent purification via flash chromatography on silica gel (10:1 hexanes:ethyl acetate) afforded the title compound as a clear liquid (1.54 g, $79 \%$ yield). $\mathrm{R}_{f}=0.40$ (10:1 hexanes: ethyl acetate). ${ }^{1} \mathrm{H}$ NMR $\left(500 \mathrm{MHz}, \mathrm{CDCl}_{3}\right) \delta 7.74$ $(\mathrm{d}, J=8.5 \mathrm{~Hz}, 2 \mathrm{H}) ; 7.29(\mathrm{~d}, J=8 \mathrm{~Hz}, 2 \mathrm{H}) ; 5.71-5.80(\mathrm{~m}, 1 \mathrm{H}) ; 5.28(\mathrm{dq}, J=17,1.5 \mathrm{~Hz}$, $1 \mathrm{H}) ; 5.23(\mathrm{dq}, J=10,1 \mathrm{~Hz}, 1 \mathrm{H}) ; 4.07$ (t, $J=2.5 \mathrm{~Hz}, 2 \mathrm{H}) ; 3.81(\mathrm{~d}, J=7 \mathrm{~Hz}, 2 \mathrm{H}) ; 2.43$ (s, $3 \mathrm{H}) ; 1.90(\mathrm{tt}, J=7,2 \mathrm{~Hz}, 2 \mathrm{H}) ; 1.16-1.29(\mathrm{~m}, 6 \mathrm{H}) ; 0.88(\mathrm{t}, J=7 \mathrm{~Hz}, 3 \mathrm{H}) .{ }^{13} \mathrm{C} \mathrm{NMR}$ $\left(125 \mathrm{MHz}, \mathrm{CDCl}_{3}\right) \delta 143.39,136.39,132.41,129.51,128.05,119.80,86.50,72.47$, 
49.09, 36.55, 31.15, 28.25, 22.31, 21.73, 18.60, 14.17. IR (thin film NaCl): 3083, 2957, 2931, 2860, 1644, 1598, 1496, 1434, 1350, 1164, 1093. HRMS (ESI) m/z 320.169 [(M + $\mathrm{H})^{+}$; calcd for $\left.\mathrm{C}_{18} \mathrm{H}_{25} \mathrm{NO}_{2} \mathrm{~S}: 320.168\right]$.

\section{Alkene-Directed Reductive Coupling of Alkynes and Aldehydes.}

Table 1a. Directing Effects of Tethered Alkenes in the Presence of a Phosphine Additive. ${ }^{\mathrm{a}}$

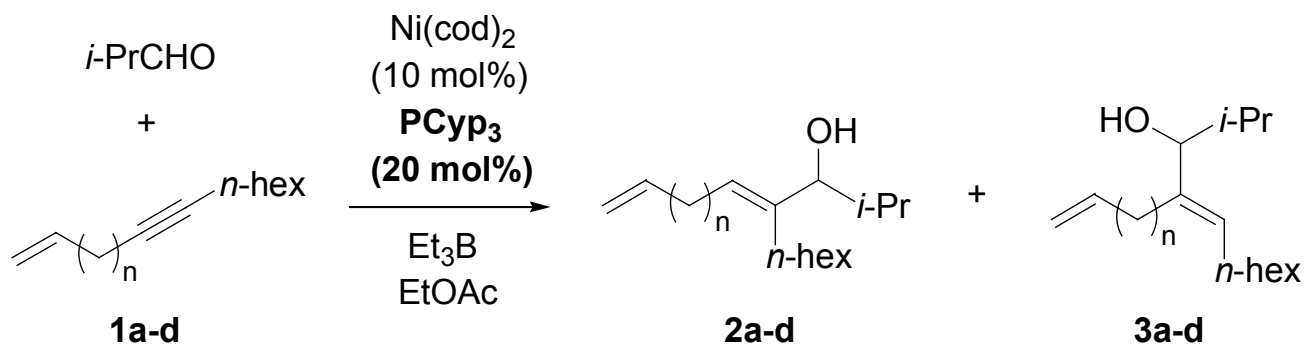

\begin{tabular}{|c|c|c|c|c|}
\hline entry & alkyne & $\mathrm{n}$ & yield (\%) & $\begin{array}{c}\text { regioselectivity } \\
(\mathbf{2}: \mathbf{3})^{b}\end{array}$ \\
\hline 1 & $\mathbf{1 a}$ & 1 & 75 & $54: 46$ \\
\hline 2 & $\mathbf{1 b}$ & 2 & 84 & $47: 53$ \\
\hline 3 & $\mathbf{1 c}$ & $\mathbf{3}$ & $\mathbf{4 5}$ & $\mathbf{5}:>\mathbf{9 5}$ \\
\hline 4 & $\mathbf{1 d}$ & 4 & 50 & $50: 50$ \\
\hline 5 & $n$-pentyl-C $\equiv \mathrm{C}-n$-hexyl & n.a. & 77 & $51: 49$ \\
\hline
\end{tabular}

${ }^{a}$ See below (General Procedure B) for experimental procedure. ${ }^{b}$ Determined by ${ }^{1} \mathrm{H}$ $\mathrm{NMR}$ and/or GC. $\mathrm{PCyp}_{3}=$ tricyclopentylphosphine.

General Procedure A (no additive): In a glovebox, $\mathrm{Ni}(\mathrm{cod})_{2}(14 \mathrm{mg}, 0.05$ mmol) was placed into a $25 \mathrm{~mL}$ oven-dried, single-necked round-bottom flask, and the flask was then sealed with a rubber septum. The flask was removed from the glovebox, placed under argon, and ethyl acetate $(0.5 \mathrm{~mL})$ was added via syringe, followed immediately by $\mathrm{Et}_{3} \mathrm{~B}(0.15 \mathrm{~mL}, 1.0 \mathrm{mmol})$. The resulting solution was then cooled to 0 ${ }^{\circ} \mathrm{C}$, and isobutyraldehyde $(90 \mu \mathrm{L}, 1.0 \mathrm{mmol})$ was added dropwise via microsyringe. After stirring for $5 \mathrm{~min}$, the enyne $(0.5 \mathrm{mmol})$ was added. The reaction was allowed to gradually warm to room temperature and stir for $15 \mathrm{~h}$. The septa was then removed and the reaction opened to air for 30 min to promote quenching of the catalyst. The crude 
mixture was purified by flash chromatography on silica gel using a solvent gradient (hexanes: ethyl acetate; 50:1 to 10:1).

General Procedure B ( (Cyp $_{3}$ additive): In a glovebox, $\mathrm{Ni}(\mathrm{cod})_{2}(14 \mathrm{mg}, 0.05$ $\mathrm{mmol})$, and $\mathrm{PCyp}_{3}(28 \mu \mathrm{L}, 0.1 \mathrm{mmol})$ were placed into a $25 \mathrm{~mL}$ oven-dried, singlenecked round-bottom flask, which was then sealed with a rubber septum. The flask was removed from the glovebox, placed under argon, and ethyl acetate $(0.5 \mathrm{~mL})$ was added via syringe, followed immediately by $\mathrm{Et}_{3} \mathrm{~B}(0.15 \mathrm{~mL}, 1.0 \mathrm{mmol})$. The resulting solution was then cooled to $0{ }^{\circ} \mathrm{C}$, and isobutyraldehyde $(90 \mu \mathrm{L}, 1.0 \mathrm{mmol})$ was added dropwise via microsyringe. After stirring for $5 \mathrm{~min}$, the enyne $(0.5 \mathrm{mmol})$ was added. The reaction was allowed to gradually warm to room temperature and stir for $15 \mathrm{~h}$. The septa was then removed and the reaction opened to air for $30 \mathrm{~min}$ to promote quenching of the catalyst. The crude mixture was purified by flash chromatography on silica gel using a solvent gradient (hexanes: ethyl acetate; 50:1 to 10:1).

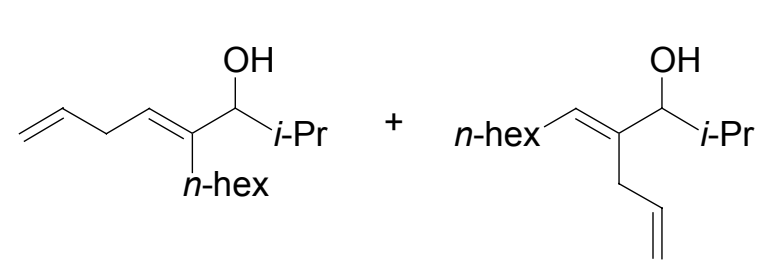

4-But-3-enylidene-2-methyl-decan-3-ol (2a) and 4-allyl-2-methyl-undec-4-en-3ol (3a).

\section{Procedure A (standard conditions):}

Reaction of isobutyraldehyde and $\mathbf{1 a}$ afforded $<5 \%$ yield of $\mathbf{2 a}$ and $\mathbf{3 a}$.

Procedure B (half-scale): Reaction of isobutyraldehyde ( $45 \mu \mathrm{L}, 0.5 \mathrm{mmol})$ and $\mathbf{1 a}$ (38 $\mathrm{mg}, 0.25 \mathrm{mmol})$ in the presence of $\mathrm{Ni}(\operatorname{cod})_{2}(7 \mathrm{mg}, 0.025 \mathrm{mmol}), \mathrm{PCyp}_{3}(14 \mu \mathrm{L}, 0.05$ $\mathrm{mmol})$, and $\mathrm{Et}_{3} \mathrm{~B}(75 \mu \mathrm{L}, 0.5 \mathrm{mmol})$ in EtOAc $(0.25 \mathrm{~mL})$ afforded a $54: 46$ mixture of regioisomers $\mathbf{2 a}$ and $\mathbf{3 a}$ as a clear oil (42 $\mathrm{mg}, 75 \%$ yield). $\mathrm{R}_{f}=0.37$ (10:1 hexanes: ethyl acetate). ${ }^{1} \mathrm{H}$ NMR $\left(500 \mathrm{MHz}, \mathrm{CDCl}_{3}\right) \delta 5.78-5.87(\mathrm{~m}, 2 \mathrm{H}) ; 5.46(\mathrm{t}, J=7.5 \mathrm{~Hz}, 1 \mathrm{H})$; $5.40(\mathrm{t}, J=7.5 \mathrm{~Hz}, 1 \mathrm{H}) ; 4.95-5.10(\mathrm{~m}, 4 \mathrm{H}) ; 3.69$ (d, $J=7 \mathrm{~Hz}, 1 \mathrm{H}) ; 3.66(\mathrm{~d}, J=7.5 \mathrm{~Hz}$, $1 \mathrm{H}) ; 2.81-2.84(\mathrm{~m}, 4 \mathrm{H}) ; 1.95-2.08(\mathrm{~m}, 4 \mathrm{H}) ; 1.76-1.83(\mathrm{~m}, 2 \mathrm{H}) ; 1.24-1.44(\mathrm{~m}$, 16H); 0.97 (d, $J=7 \mathrm{~Hz}, 3 \mathrm{H}) ; 0.96$ (d, $J=6.5 \mathrm{~Hz}, 3 \mathrm{H}) ; 0.89$ (t, $J=7 \mathrm{~Hz}, 3 \mathrm{H}) ; 0.89$ (t, $J=$ $7 \mathrm{~Hz}, 3 \mathrm{H}) ; 0.86$ (d, $J=6.5 \mathrm{~Hz}, 3 \mathrm{H}) ; 0.82(\mathrm{~d}, J=6.5 \mathrm{~Hz}, 3 \mathrm{H}) .{ }^{13} \mathrm{C}$ NMR $(125 \mathrm{MHz}$, $\left.\mathrm{CDCl}_{3}\right) \delta 142.78,137.94,137.48,137.33,129.73,124.84$ (instrument peak), 124.54, 115.20, 114.90, 100.00 (instrument peak), 83.31, 82.75, 32.12, 31.95, 31.90, 31.78, 
$31.67,30.22,30.18,29.80,29.29,28.07,27.82,22.89,22.85,20.12,19.99,18.41,18.19$, 14.32, 14.31. IR (thin film NaCl): 3408, 3079, 2958, 2929, 2872, 2859, 1716, 1667, $1637,1468,1380,1367,1249,1172,1010$. HRMS (ESI) $m / z 247.204\left[(\mathrm{M}+\mathrm{Na})^{+}\right.$; calcd for $\left.\mathrm{C}_{15} \mathrm{H}_{28} \mathrm{O}: 247.203\right]$.

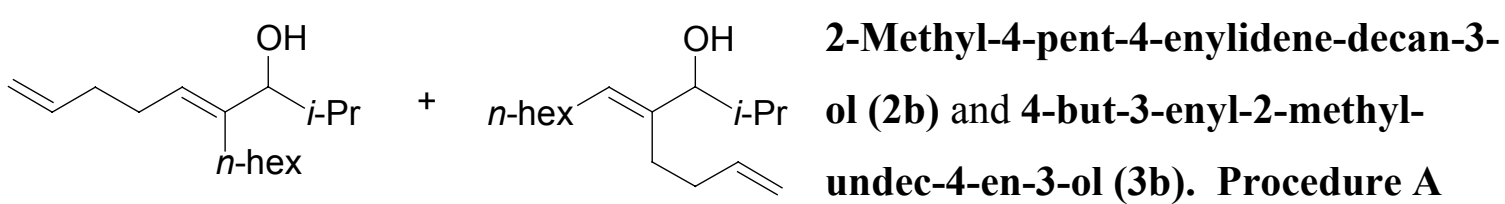

(standard conditions): Reaction of isobutyraldehyde and $\mathbf{1 b}(82 \mathrm{mg}, 0.5 \mathrm{mmol})$ afforded $<5 \%$ yield of $\mathbf{2 b}$ and $\mathbf{3 b}$. Procedure $\mathbf{B}$ (standard conditions): Reaction of isobutyraldehyde and $\mathbf{1 b}(82 \mathrm{mg}, 0.5 \mathrm{mmol}$ ) afforded a 47:53 mixture of regioisomers $\mathbf{2 b}$ and $\mathbf{3 b}$ (100 mg, 84\% yield). $\mathrm{R}_{f}=0.37$ (10:1 hexanes: ethyl acetate). ${ }^{1} \mathrm{H}$ NMR (500 $\left.\mathrm{MHz}, \mathrm{CDCl}_{3}\right) \delta 5.79-5.90(\mathrm{~m}, 2 \mathrm{H}) ; 5.39$ (t, $\left.J=7 \mathrm{~Hz}, 1 \mathrm{H}\right) ; 5.36(\mathrm{t}, J=7 \mathrm{~Hz}, 1 \mathrm{H}) ; 5.00$ $5.06(\mathrm{~m}, 2 \mathrm{H}) ; 4.96-4.99(\mathrm{~m}, 2 \mathrm{H}) ; 3.66(\mathrm{~d}, J=7 \mathrm{~Hz}, 1 \mathrm{H}) ; 3.64(\mathrm{~d}, J=7 \mathrm{~Hz}, 1 \mathrm{H}) ; 1.93-$ $2.20(\mathrm{~m}, 12 \mathrm{H}) ; 1.73-1.83$ (m, 2H); $1.24-1.43$ (m, 16H); 0.97 (d, $J=7 \mathrm{~Hz}, 3 \mathrm{H}) ; 0.95$ $(\mathrm{d}, J=7 \mathrm{~Hz}, 3 \mathrm{H}) ; 0.89$ (t, $J=7 \mathrm{~Hz}, 3 \mathrm{H}) ; 0.84(\mathrm{~d}, J=7 \mathrm{~Hz}, 3 \mathrm{H}) ; 0.83$ (d, $J=7 \mathrm{~Hz}, 3 \mathrm{H})$. ${ }^{13} \mathrm{C}$ NMR $\left(125 \mathrm{MHz}, \mathrm{CDCl}_{3}\right) \delta 141.98,140.29,139.09,138.63,128.91,126.85,114.94$, $114.71,83.03,82.81,34.29,34.19,31.99,31.92,31.90,31.79,30.20,30.18,29.97,29.29$, $28.22,27.83,27.35,27.22,22.90,22.86,20.10,20.02,18.44,18.23,14.33,14.31$. IR (thin film NaCl): 3421, 3078, 2957, 2928, 2871, 2858, 1824, 1726, 1641, 1467, 1415, $1380,1366,1295,1247,1169,1129,1008$. HRMS (ESI) $\mathrm{m} / z 261.220\left[(\mathrm{M}+\mathrm{Na})^{+}\right.$; calcd for $\left.\mathrm{C}_{16} \mathrm{H}_{30} \mathrm{O}: 261.219\right]$.

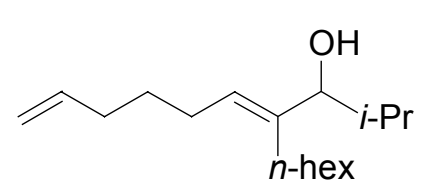

\section{4-Hexyl-2-methyl-deca-4,9-dien-3-ol (2c). Procedure A}

(half-scale): Reaction of isobutyraldehyde ( $45 \mu \mathrm{L}, 0.5 \mathrm{mmol})$ and $1 \mathrm{c}(45 \mathrm{mg}, 0.25 \mathrm{mmol})$ in the presence of $\mathrm{Ni}(\mathrm{cod})_{2}(7 \mathrm{mg}$, $0.025 \mathrm{mmol})$ and $\mathrm{Et}_{3} \mathrm{~B}(75 \mu \mathrm{L}, 0.5 \mathrm{mmol})$ in $\operatorname{EtOAc}(0.25 \mathrm{~mL})$ afforded an $85: 15$ mixture of the title compound and the corresponding alkylative coupling product (transfer of an ethyl group instead of a hydrogen from $\mathrm{Et}_{3} \mathrm{~B}$ ) ( $34 \mathrm{mg}, 53 \%$ yield (46\% reductive), $>95: 5$ regioselectivity). Structure of $\mathbf{2 c}$ was confirmed via ozonolysis (see S18 for details). An analytically pure sample of $\mathbf{2 c}$ was obtained via flash chromatography on silica gel 
impregnated with $5 \%$ silver nitrate. $\quad \mathrm{R}_{f}=0.40$ (10:1 hexanes: ethyl acetate). ${ }^{1} \mathrm{H}$ NMR $\left(500 \mathrm{MHz}, \mathrm{CDCl}_{3}\right) \delta 5.78-5.87(\mathrm{~m}, 1 \mathrm{H}) ; 5.35(\mathrm{t}, J=7.5 \mathrm{~Hz}, 1 \mathrm{H}) ; 4.99-5.04(\mathrm{~m}, 1 \mathrm{H})$; $4.95-4.98(\mathrm{~m}, 1 \mathrm{H}) ; 3.66(\mathrm{~d}, J=7.5 \mathrm{~Hz}, 1 \mathrm{H}) ; 1.92-2.10$ (m, 6H); 1.78 (oct., $J=7 \mathrm{~Hz}$, $1 \mathrm{H}) ; 1.44-1.51(\mathrm{~m}, 2 \mathrm{H}) ; 1.24-1.43(\mathrm{~m}, 8 \mathrm{H}) ; 0.96(\mathrm{~d}, J=7 \mathrm{~Hz}, 3 \mathrm{H}) ; 0.89$ (t, $J=7 \mathrm{~Hz}$, $3 \mathrm{H}) ; 0.84(\mathrm{~d}, J=7 \mathrm{~Hz}, 3 \mathrm{H}) .{ }^{13} \mathrm{C} \mathrm{NMR}\left(125 \mathrm{MHz}, \mathrm{CDCl}_{3}\right) \delta 141.79,139.02,127.43$, $114.73,82.89,33.67,31.91,31.90,31.82,30.27,30.18,29.30,28.17,27.19,22.90,20.11$, 18.26, 14.34. IR (thin film NaCl): 3623, 3428, 3078, 2956, 2929, 2871, 2859, 1823, 1641, 1468, 1379, 1365, 1295, 1246, 1169, 1130, 1116, 1007. HRMS (ESI) $m / z 275.235$ $\left[(\mathrm{M}+\mathrm{Na})^{+}\right.$; calcd for $\left.\mathrm{C}_{17} \mathrm{H}_{32} \mathrm{O}: 275.235\right]$. Regioselectivity confirmed by GC analysis (chiral B-PH, $125^{\circ} \mathrm{C}, 2.5 \mathrm{~mL} / \mathrm{min}$ ): 21.30, $22.06 \mathrm{~min}$.

Irradiation of the vinyl proton resulted in a $2 \%$ nOe of the carbinol proton, consistent with an $E$ olefin geometry in the observed allylic alcohol regioisomer.
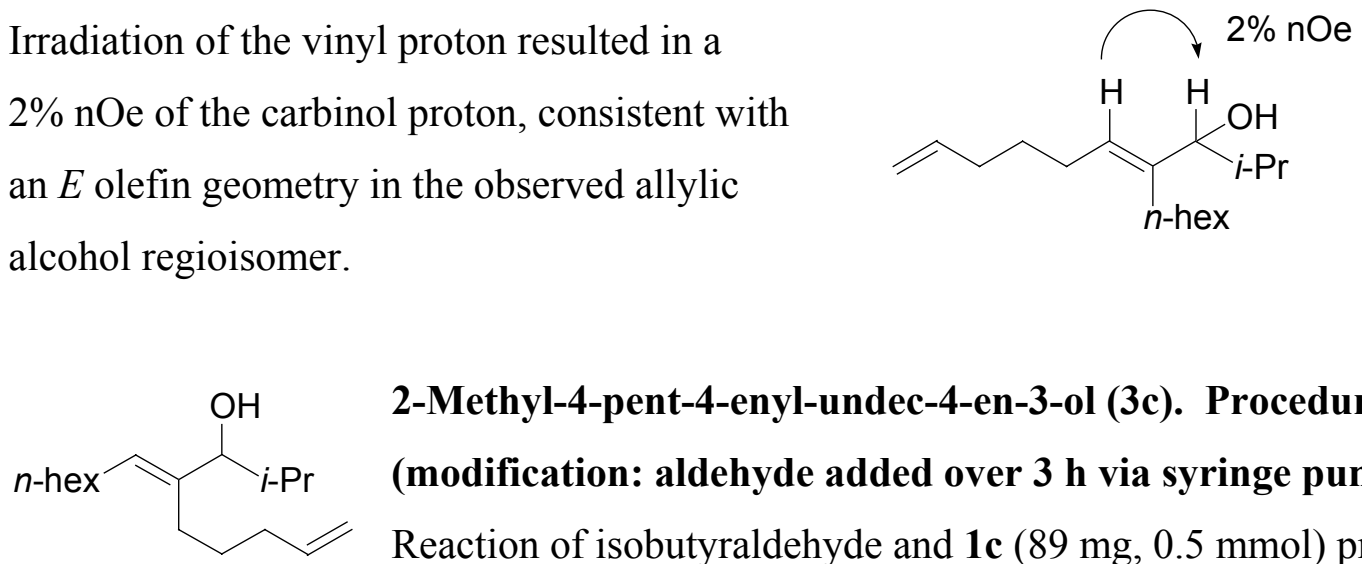
2-Methyl-4-pent-4-enyl-undec-4-en-3-ol (3c). Procedure B (modification: aldehyde added over $3 \mathrm{~h}$ via syringe pump):

Reaction of isobutyraldehyde and $\mathbf{1 c}(89 \mathrm{mg}, 0.5 \mathrm{mmol})$ provided $3 \mathbf{c}$ as a clear oil (57 mg, 45\% yield). Following initial purification, flash chromatography on silica gel impregnated with 5\% silver nitrate was required to remove minor impurities. Structure of 3c was confirmed via ozonolysis (see S20 for details). $\mathrm{R}_{f}=0.40$ (10:1 hexanes: ethyl acetate). ${ }^{1} \mathrm{H}$ NMR $\left(500 \mathrm{MHz}, \mathrm{CDCl}_{3}\right) \delta 5.79-5.87(\mathrm{~m}, 1 \mathrm{H}) ; 5.36(\mathrm{t}, J=7$ $\mathrm{Hz}, 1 \mathrm{H}) ; 5.01-5.05$ (m, 1H); $4.96-4.99$ (m, 1H); 3.65 (d, $J=7 \mathrm{~Hz}, 1 \mathrm{H}) ; 1.95-2.13$ (m, 6H); 1.78 (oct., $J=7$ Hz, 1H); $1.46-1.56$ (m, 2H); $1.24-1.40$ (m, 8H); 0.96 (d, $J=$ $7 \mathrm{~Hz}, 3 \mathrm{H}) ; 0.89(\mathrm{t}, J=7 \mathrm{~Hz}, 3 \mathrm{H}) ; 0.83(\mathrm{~d}, J=7 \mathrm{~Hz}, 3 \mathrm{H}) .{ }^{13} \mathrm{C} \mathrm{NMR}\left(125 \mathrm{MHz}, \mathrm{CDCl}_{3}\right) \delta$ $140.95,138.88,128.39,114.86,83.05,34.55,31.98,31.80,29.99,29.46,29.28,27.78$, 27.53, 22.85, 20.08, 18.35, 14.32. IR (thin film NaCl): 3415, 3077, 2956, 2928, 2858, 1823, 1722, 1641, 1467, 1379, 1366, 1297, 1249, 1168, 1113, 1010. HRMS (ESI) $m / z$ $275.235\left[(\mathrm{M}+\mathrm{Na})^{+}\right.$; calcd for $\left.\mathrm{C}_{17} \mathrm{H}_{32} \mathrm{O}: 275.235\right]$. Regioselectivity confirmed by GC analysis (chiral B-PH, $125^{\circ} \mathrm{C}, 2.5 \mathrm{~mL} / \mathrm{min}$ ): $21.30,22.06 \mathrm{~min}$. 
Irradiation of the vinyl proton resulted in a

$4 \%$ nOe of the carbinol proton, consistent with an $E$ olefin geometry in the observed allylic alcohol regioisomer.
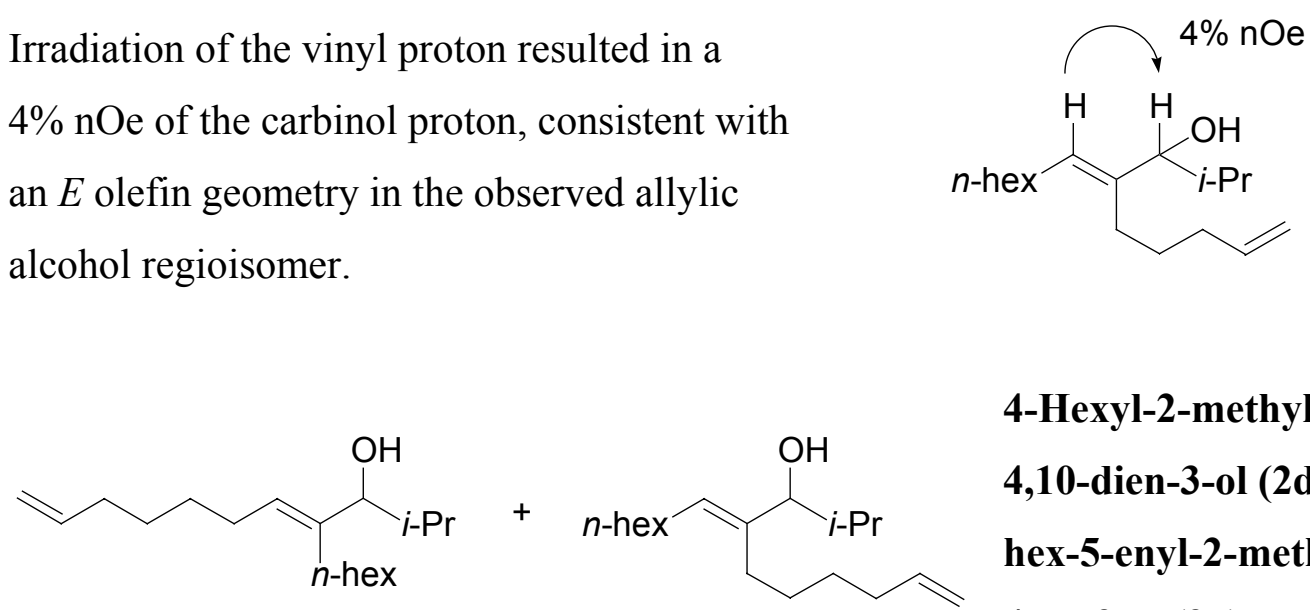

4-Hexyl-2-methyl-undeca4,10-dien-3-ol (2d) and 4hex-5-enyl-2-methyl-undec4-en-3-ol (3d).

Procedure A (reduced scale): Reaction of isobutyraldehyde ( $35 \mu \mathrm{L}, 0.38 \mathrm{mmol})$ and $\mathbf{1 d}$ $(36 \mathrm{mg}, 0.19 \mathrm{mmol})$ in the presence of $\mathrm{Ni}(\mathrm{cod})_{2}(5 \mathrm{mg}, 19 \mu \mathrm{mol})$ and $\mathrm{Et}_{3} \mathrm{~B}(60 \mu \mathrm{L}, 0.40$ mmol) in EtOAc ( $200 \mu \mathrm{L})$ afforded $<5 \%$ yield of $\mathbf{2 d}$ and $\mathbf{3 d}$.

Procedure B (reduced scale): Reaction of isobutyraldehyde ( $35 \mu \mathrm{L}, 0.38 \mathrm{mmol})$ and $\mathbf{1 d}$ (36 mg, $0.19 \mathrm{mmol})$ in the presence of $\mathrm{Ni}(\operatorname{cod})_{2}(5 \mathrm{mg}, 19 \mu \mathrm{mol}), \mathrm{PCyp}_{3}(11 \mu \mathrm{L}, 38$ $\mu \mathrm{mol})$, and $\mathrm{Et}_{3} \mathrm{~B}(60 \mu \mathrm{L}, 0.40 \mathrm{mmol})$ in EtOAc $(200 \mu \mathrm{L})$ afforded a 50:50 mixture of regioisomers $\mathbf{2 d}$ and $\mathbf{3 d}$ as a clear oil (27 $\mathrm{mg}, 52 \%$ yield). $\mathrm{R}_{f}=0.46$ (10:1 hexanes: ethyl acetate). ${ }^{1} \mathrm{H}$ NMR (500 MHz, $\left.\mathrm{CDCl}_{3}\right) \delta 5.77-5.86(\mathrm{~m}, 2 \mathrm{H}) ; 5.36(\mathrm{t}, J=7 \mathrm{~Hz}, 1 \mathrm{H}) ; 5.35$ (t, $J=7 \mathrm{~Hz}, 1 \mathrm{H}) ; 4.98-5.04(\mathrm{~m}, 2 \mathrm{H}) ; 4.93-4.96(\mathrm{~m}, 2 \mathrm{H}) ; 3.65$ (d, $J=7.5 \mathrm{~Hz}, 2 \mathrm{H}) ; 1.92$ $-2.10(\mathrm{~m}, 12 \mathrm{H}) ; 1.74-1.82(\mathrm{~m}, 2 \mathrm{H}) ; 1.22-1.45$ (m, 24H); 0.96 (d, $J=7 \mathrm{~Hz}, 3 \mathrm{H}) ; 0.96$ (d, $J=6.5 \mathrm{~Hz}, 3 \mathrm{H}) ; 0.90$ (t, $J=7 \mathrm{~Hz}, 3 \mathrm{H}) ; 0.89$ (t, $J=7 \mathrm{~Hz}, 3 \mathrm{H}) ; 0.84(\mathrm{~d}, J=7 \mathrm{~Hz}, 3 \mathrm{H})$; $0.83(\mathrm{~d}, J=7 \mathrm{~Hz}, 3 \mathrm{H}) .{ }^{13} \mathrm{C} \mathrm{NMR}\left(125 \mathrm{MHz}, \mathrm{CDCl}_{3}\right) \delta 141.54,141.11,139.20,139.17$, $128.17,127.71,114.56,114.51,82.98,82.94,33.89,33.81,32.00,31.93,31.83,31.82$, $30.28,30.20,30.02,29.70,29.67,29.50,29.30,28.85,28.17,27.92,27.78,27.58,22.90$, 22.86, 20.10, 20.09, 18.31, 18.29, 14.34, 14.32. IR (thin film NaCl): 3438, 3078, 2957, 2929, 2858, 1821, 1714, 1660, 1641, 1467, 1415, 1379, 1366, 1296, 1247, 1169, 1102, 1009. HRMS (ESI) $m / z 289.251$ [(M+Na) $)^{+}$calcd for $\left.\mathrm{C}_{18} \mathrm{H}_{34} \mathrm{O}: 289.250\right]$.

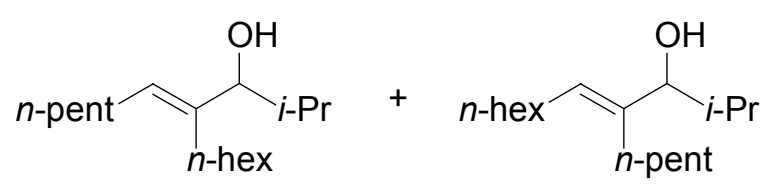

4-Hexyl-2-methyl-dec-4-en-3-ol (5a) and 2-methyl-4-pentyl-undec-4-en-3-ol (5b). Procedure A (standard conditions): 
Reaction of isobutyraldehyde and $4(90 \mathrm{mg}, 0.5 \mathrm{mmol})$ afforded an 85:15 mixture of the title compounds and the corresponding alkylative coupling products (transfer of an ethyl group instead of a hydrogen from $\mathrm{Et}_{3} \mathrm{~B}$ ) as a clear oil ( $36 \mathrm{mg}, 28 \%$ yield ( $24 \%$ reductive), 51:49 mixture of regioisomers $\mathbf{5 a}$ and $\mathbf{5 b}$ ).

Procedure B (standard conditions): Reaction of isobutyraldehyde and 4 (90 $\mathrm{mg}, 0.5$ mmol) afforded a 51:49 mixture of regioisomers $\mathbf{5 a}$ and $\mathbf{5 b}$ as a clear oil $(98 \mathbf{m g}, 77 \%$ yield). $\mathrm{R}_{f}=0.39$ (10:1 hexanes: ethyl acetate). ${ }^{1} \mathrm{H} \mathrm{NMR}\left(500 \mathrm{MHz}, \mathrm{CDCl}_{3}\right) \delta 5.35(\mathrm{t}, J$ $=7 \mathrm{~Hz}, 1 \mathrm{H}) ; 3.65(\mathrm{~d}, J=7.5 \mathrm{~Hz}, 1 \mathrm{H}) ; 1.92-2.07$ (m, 4H); 1.78 (oct., $J=7 \mathrm{~Hz}, 1 \mathrm{H}) ; 1.24$ $-1.44(\mathrm{~m}, 14 \mathrm{H}) ; 0.96$ (d, $J=6 \mathrm{~Hz}, 3 \mathrm{H}) ; 0.87-0.92(\mathrm{~m}, 6 \mathrm{H}) ; 0.84(\mathrm{~d}, J=6.5 \mathrm{~Hz}, 3 \mathrm{H})$. ${ }^{13} \mathrm{C} \mathrm{NMR}\left(125 \mathrm{MHz}, \mathrm{CDCl}_{3}\right) \delta 141.33,128.01,83.01,83.00,32.71,32.00,31.93,31.84$, $31.83,30.30,30.20,30.03,30.00,29.74,29.30,28.15,28.10,27.76,27.72,22.90,22.86$, 22.80, 22.74, 20.09, 18.32, 14.34, 14.32, 14.31, 14.30. IR (thin film NaCl): 3624, 3423, 2957, 2927, 2872, 2859, 1713, 1661, 1467, 1379, 1366, 1297, 1244, 1169, 1105, 1008. HRMS (ESI) $m / z 277.251\left[(\mathrm{M}+\mathrm{Na})^{+}\right.$; calcd for $\left.\mathrm{C}_{17} \mathrm{H}_{34} \mathrm{O}: 277.250\right]$. Regioselectivity determined by $\mathrm{GC}$ analysis (chiral B-PH, $110^{\circ} \mathrm{C}, 2.0 \mathrm{~mL} / \mathrm{min}$ ): 51.08, $52.04 \mathrm{~min}$.

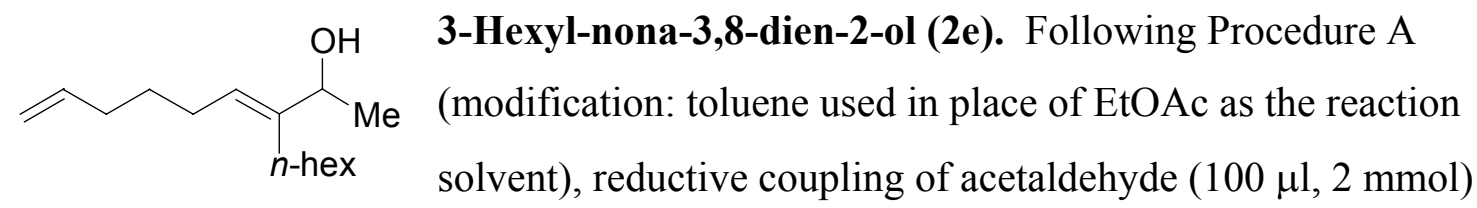
and 1c (89 mg, $0.5 \mathrm{mmol}$ ) afforded the title compound as a clear oil (77 $\mathrm{mg}, 69 \%$ yield, $>95: 5$ regioselectivity). $\mathrm{R}_{f}=0.19$ (10:1 hexanes: ethyl acetate). ${ }^{1} \mathrm{H} \mathrm{NMR}(500 \mathrm{MHz}$, $\left.\mathrm{CDCl}_{3}\right) \delta 5.78-5.86(\mathrm{~m}, 1 \mathrm{H}) ; 5.41(\mathrm{t}, J=7 \mathrm{~Hz}, 1 \mathrm{H}) ; 4.99-5.05(\mathrm{~m}, 1 \mathrm{H}) ; 4.94-4.98$ (m, 1H); 4.23 (q, $J=6.5 \mathrm{~Hz}, 1 \mathrm{H}$ ); $1.95-2.12$ (m, 6H); 1.46 (quin., $J=7.5 \mathrm{~Hz}, 2 \mathrm{H}$ ); 1.28 $-1.42(\mathrm{~m}, 8 \mathrm{H}) ; 1.27$ (d, $J=6.5 \mathrm{~Hz}, 3 \mathrm{H}) ; 0.90(\mathrm{t}, J=6.5 \mathrm{~Hz}, 3 \mathrm{H}) .{ }^{13} \mathrm{C} \mathrm{NMR}(125 \mathrm{MHz}$, $\left.\mathrm{CDCl}_{3}\right) \delta 143.84,139.00,125.15,114.72,72.31,33.65,31.90,30.11,30.02,29.22,27.82$, 27.13, 22.88, 22.58, 14.33. IR (thin film NaCl): 3349, 3078, 2957, 2928, 2858, 1641, $1458,1415,1378,1366,1283,1116,1062$. HRMS (ESI) $m / z 247.203\left[(\mathrm{M}+\mathrm{Na})^{+}\right.$; calcd for $\left.\mathrm{C}_{15} \mathrm{H}_{28} \mathrm{O}: 247.203\right]$. 


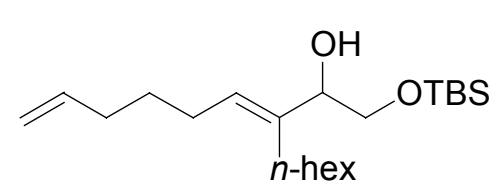

1-(tert-Butyl-dimethyl-silanyloxy)-3-hexyl-nona-3,8-

dien-2-ol (2f). Following Procedure A (modification:

toluene used in place of EtOAc as the reaction solvent),

reductive coupling of (tert-butyldimethylsilyloxy)acetaldehyde (190 $\mu \mathrm{L}, 1 \mathrm{mmol})$ and 1c (89 mg, $0.5 \mathrm{mmol}$ ) afforded the title compound as a clear oil (102 mg, 58\% yield, >95:5 regioselectivity). $\mathrm{R}_{f}=0.42$ (10:1 hexanes: ethyl acetate). ${ }^{1} \mathrm{H}$ NMR $\left(500 \mathrm{MHz}, \mathrm{CDCl}_{3}\right) \delta$ $5.77-5.86(\mathrm{~m}, 1 \mathrm{H}) ; 5.48$ (t, $J=7 \mathrm{~Hz}, 1 \mathrm{H}) ; 5.10(\mathrm{dd}, J=17,1 \mathrm{~Hz}, 1 \mathrm{H}) ; 4.96(\mathrm{dt}, J=10$, $1 \mathrm{~Hz}, 1 \mathrm{H}) ; 4.08$ (dd, $J=8.5,3 \mathrm{~Hz}, 1 \mathrm{H}) ; 3.64(\mathrm{dd}, J=10,3 \mathrm{~Hz}, 1 \mathrm{H}) ; 3.42(\mathrm{dd}, J=10,8.5$ $\mathrm{Hz}, 1 \mathrm{H}$ ); 2.03 - 2.12 (m, 5H); $1.87-1.94$ (m, 1H); 1.47 (quin., $J=7.5 \mathrm{~Hz}, 2 \mathrm{H}$ ); 1.24 $1.40(\mathrm{~m}, 8 \mathrm{H}) ; 0.91$ (s, 9H); 0.89 (t, $J=7 \mathrm{~Hz}, 3 \mathrm{H}) ; 0.09$ (s, 6H). ${ }^{13} \mathrm{C}$ NMR $(125 \mathrm{MHz}$, $\left.\mathrm{CDCl}_{3}\right) \delta 139.03,138.39,127.21,114.68,75.70,67.27,33.67,31.91,29.87,29.78,29.19$, $28.58,27.19,26.11,22.86,18.52,14.32,-5.08$, -5.11. IR (thin film NaCl): 3572, 3472, 3078, 2956, 2929, 2858, 1824, 1730, 1641, 1471, 1464, 1390, 1362, 1316, 1255, 1223, 1099, 1057, 1006, 992. HRMS (ESI) $m / z 377.284\left[(\mathrm{M}+\mathrm{Na})^{+}\right.$; calcd for $\mathrm{C}_{21} \mathrm{H}_{42} \mathrm{O}_{2} \mathrm{Si}$ : 377.285].

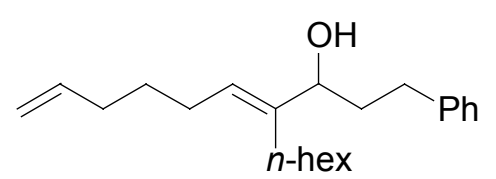

\section{4-Hexyl-1-phenyl-deca-4,9-dien-3-ol (2g). Following} Procedure A (modification: toluene used in place of EtOAc as the reaction solvent), reductive coupling of 3-

phenylpropionaldehyde (132 $\mathrm{L}, 1 \mathrm{mmol})$ and $1 \mathbf{c}(89 \mathrm{mg}, 0.5 \mathrm{mmol})$ afforded the title compound as a clear oil $\left(95 \mathrm{mg}, 60 \%\right.$ yield, $>95: 5$ regioselectivity). $\mathrm{R}_{f}=0.23$ (10:1 hexanes: ethyl acetate). ${ }^{1} \mathrm{H}$ NMR (500 MHz, $\left.\mathrm{CDCl}_{3}\right) \delta 7.27-7.31(\mathrm{~m}, 2 \mathrm{H}) ; 7.17-7.22$ (m, 3H); $5.78-5.87(\mathrm{~m}, 1 \mathrm{H}) ; 5.41(\mathrm{t}, J=7 \mathrm{~Hz}, 1 \mathrm{H}) ; 5.00-5.04(\mathrm{~m}, 1 \mathrm{H}) ; 4.95-4.98(\mathrm{~m}$, $1 \mathrm{H}) ; 4.05(\mathrm{t}, J=6.5 \mathrm{~Hz}, 1 \mathrm{H}) ; 2.70-2.76(\mathrm{~m}, 1 \mathrm{H}) ; 2.60-2.66(\mathrm{~m}, 1 \mathrm{H}) ; 1.96-2.11(\mathrm{~m}$, $6 \mathrm{H}$ ); $1.84-1.89$ (m, 2H); 1.47 (quin., $J=7.5 \mathrm{~Hz}, 2 \mathrm{H}) ; 1.24-1.42(\mathrm{~m}, 8 \mathrm{H}) ; 0.89$ (t, $J=7$ $\mathrm{Hz}, 3 \mathrm{H}) .{ }^{13} \mathrm{C} \mathrm{NMR}\left(125 \mathrm{MHz}, \mathrm{CDCl}_{3}\right) \delta 142.41,142.39,138.94,128.65,128.55,126.82$, $125.96,114.78,76.34,37.59,33.65,32.52,31.87,30.20,30.06,29.93,27.82,27.19$, 22.87, 14.32. IR (thin film NaCl): 3360, 3077, 3064, 3027, 2954, 2928, 2858, 1940, 1821, 1727, 1641, 1604, 1496, 1455, 1415, 1378, 1301, 1154, 1048, 1031, 992. HRMS (ESI) $m / z 337.250\left[(\mathrm{M}+\mathrm{Na})^{+}\right.$; calcd for $\left.\mathrm{C}_{22} \mathrm{H}_{34} \mathrm{O}: 337.250\right]$. 


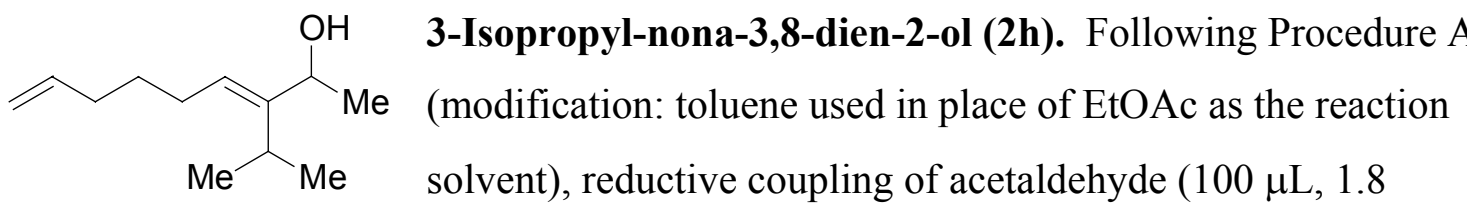

$\mathrm{mmol}$ ) and $1 \mathrm{e}(68 \mathrm{mg}, 0.5 \mathrm{mmol})$ afforded the title compound as a clear oil $(58 \mathrm{mg}, 64 \%$ yield, $>95: 5$ regioselectivity). $\mathrm{R}_{f}=0.20$ (10:1 hexanes: ethyl acetate). ${ }^{1} \mathrm{H}$ NMR (500 $\left.\mathrm{MHz}, \mathrm{CDCl}_{3}\right) \delta 5.78-5.86(\mathrm{~m}, 1 \mathrm{H}) ; 5.47(\mathrm{t}, J=7 \mathrm{~Hz}, 1 \mathrm{H}) ; 4.99-5.04(\mathrm{~m}, 1 \mathrm{H}) ; 4.95-$ 4.98 (m, 1H); 4.30 (q, $J=6.5 \mathrm{~Hz}, 1 \mathrm{H}) ; 2.76$ (sept., $J=7 \mathrm{~Hz}, 1 \mathrm{H}) ; 2.05-2.13$ (m, 4H); 1.47 (quin., $J=7 \mathrm{~Hz}, 2 \mathrm{H}) ; 1.29$ (d, $J=6.5 \mathrm{~Hz}, 3 \mathrm{H}) ; 1.11$ (d, $J=7 \mathrm{~Hz}, 3 \mathrm{H}) ; 1.05$ (d, $J=7$ $\mathrm{Hz}, 3 \mathrm{H}) .{ }^{13} \mathrm{C} \mathrm{NMR}\left(125 \mathrm{MHz}, \mathrm{CDCl}_{3}\right) \delta 149.38,138.99,124.20,114.74,68.43,33.65$, 29.36, 28.20, 26.99, 24.19, 21.97, 21.71. IR (thin film NaCl): 3361, 3078, 2962, 2929, 2872, 1824, 1641, 1460, 1415, 1365, 1304, 1282, 1217, 1150, 1111, 1060. HRMS (ESI) $m / z 205.156\left[(\mathrm{M}+\mathrm{Na})^{+}\right.$; calcd for $\left.\mathrm{C}_{12} \mathrm{H}_{22} \mathrm{O}: 205.156\right]$.

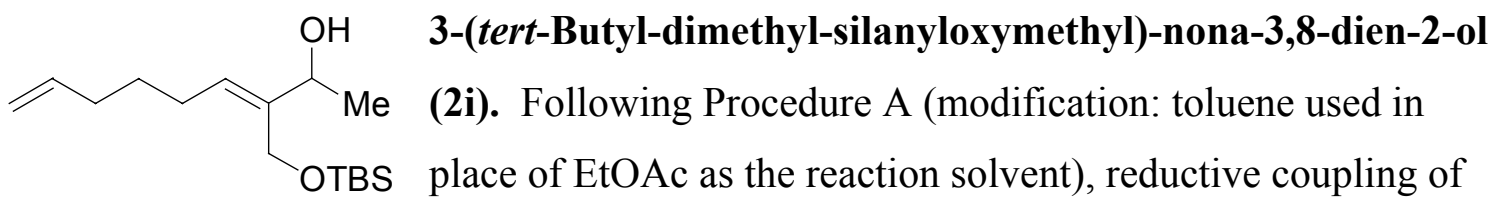
acetaldehyde $(100 \mu \mathrm{L}, 1.8 \mathrm{mmol})$ and $\mathbf{1 f}(119 \mathrm{mg}, 0.5 \mathrm{mmol})$ afforded the title compound as a clear oil ( $88 \mathrm{mg}, 62 \%$ yield, $>95: 5$ regioselectivity). $\mathrm{R}_{f}=0.40$ (10:1 hexanes: ethyl acetate). ${ }^{1} \mathrm{H}$ NMR $\left(500 \mathrm{MHz}, \mathrm{CDCl}_{3}\right) \delta 5.76-5.85(\mathrm{~m}, 1 \mathrm{H}) ; 5.49(\mathrm{t}, J=7.5 \mathrm{~Hz}, 1 \mathrm{H})$; $4.99-5.04$ (m, 1H); 4.95 - 4.98 (m, 1H); $4.31-4.40$ (m, 3H); $2.00-2.10$ (m, 4H); 1.48 (quin., $J=7.5 \mathrm{~Hz}, 2 \mathrm{H}) ; 1.34$ (d, $J=6 \mathrm{~Hz}, 3 \mathrm{H}) ; 0.92$ (s, 9H); 0.12 (s, 3H); 0.11 (s, 3H). ${ }^{13} \mathrm{C}$ NMR $\left(125 \mathrm{MHz}, \mathrm{CDCl}_{3}\right) \delta 140.04,138.70,127.74,114.94,72.43,60.20,33.45$, 28.94, 26.92, 26.07, 22.22, 18.36, -5.30. IR (thin film NaCl): 3421, 3078, 2956, 2929, 2886, 2858, 1668, 1641, 1472, 1463, 1442, 1406, 1390, 1362, 1255, 1072. HRMS (ESI) $m / z 307.206\left[(\mathrm{M}+\mathrm{Na})^{+}\right.$; calcd for $\mathrm{C}_{16} \mathrm{H}_{32} \mathrm{O}_{2} \mathrm{Si}$ : 307.206].

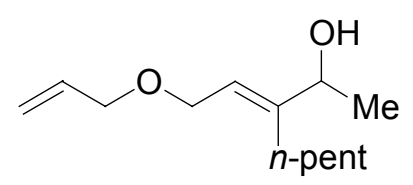

5-Allyloxy-3-pentyl-pent-3-en-2-ol (2j). Following Procedure A (modifications: toluene used in place of EtOAc as the reaction solvent, and slow addition of the enyne over $3 \mathrm{~h}$ via syringe pump), reductive coupling of acetaldehyde (100 $\mu \mathrm{L}, 1.8 \mathrm{mmol})$ and $1 \mathrm{~g}(83 \mathrm{mg}$, $0.5 \mathrm{mmol}$ ) afforded the title compound as a clear oil (64 $\mathrm{mg}, 60 \%$ yield, $>95: 5$ 
regioselectivity). $\mathrm{R}_{f}=0.17$ (5:1 hexanes: ethyl acetate). ${ }^{1} \mathrm{H}$ NMR $\left(500 \mathrm{MHz}, \mathrm{CDCl}_{3}\right) \delta$ $5.90-5.97(\mathrm{~m}, 1 \mathrm{H}) ; 5.64(\mathrm{t}, J=6.5 \mathrm{~Hz}, 1 \mathrm{H}) ; 5.27-5.32(\mathrm{~m}, 1 \mathrm{H}) ; 5.19-5.22(\mathrm{~m}, 1 \mathrm{H})$; 4.27 (q, $J=6.5 \mathrm{~Hz}, 1 \mathrm{H}) ; 4.05$ (d, $J=6.5 \mathrm{~Hz}, 2 \mathrm{H}) ; 3.99$ (dt, $J=6,1.5 \mathrm{~Hz}, 2 \mathrm{H}) ; 2.09-$ $2.16(\mathrm{~m}, 1 \mathrm{H}) ; 1.98-2.04(\mathrm{~m}, 1 \mathrm{H}) ; 1.20-1.42(\mathrm{~m}, 11 \mathrm{H}) ; 0.90(\mathrm{t}, J=7 \mathrm{~Hz}, 3 \mathrm{H}) .{ }^{13} \mathrm{C}$ NMR $\left(125 \mathrm{MHz}, \mathrm{CDCl}_{3}\right) \delta 147.75,134.98,121.25,117.42,71.63,71.58,66.49,32.40$, 29.97, 28.18, 22.66, 22.40, 14.24. IR (thin film NaCl): 3392, 2957, 2932, 2861, 1647, $1459,1367,1212,1065$. HRMS (ESI) $m / z 235.166\left[(\mathrm{M}+\mathrm{Na})^{+}\right.$; calcd for $\mathrm{C}_{13} \mathrm{H}_{24} \mathrm{O}_{2}$ : 235.167].

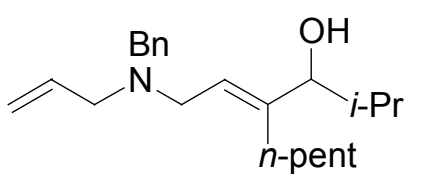

\section{6-(Allyl-benzyl-amino)-2-methyl-4-pentyl-hex-4-en-3-ol}

(2k). Following Procedure A (modification: toluene used in place of EtOAc as the reaction solvent), reductive coupling of isobutyraldehyde ( $90 \mu \mathrm{L}, 1.0 \mathrm{mmol})$ and $\mathbf{1 h}(128 \mathrm{mg}, 0.5 \mathrm{mmol})$ afforded the title compound as a clear oil (102 mg, 62\% yield, $>95: 5$ regioselectivity). $\mathrm{R}_{f}=0.22$ (5:1 hexanes: ethyl acetate). ${ }^{1} \mathrm{H}$ NMR (500 MHz, $\left.\mathrm{CDCl}_{3}\right) \delta 7.23-7.36(\mathrm{~m}, 4 \mathrm{H}) ; 5.86-5.95$ (m, 1H); 5.52 (t, $J=6.5 \mathrm{~Hz}, 1 \mathrm{H}) ; 5.20(\mathrm{dd}, J=17.5,2 \mathrm{~Hz}, 1 \mathrm{H}) ; 5.16(\mathrm{~d}, J=10 \mathrm{~Hz}, 1 \mathrm{H})$; 3.69 (d, $J=7 \mathrm{~Hz}, 1 \mathrm{H}) ; 3.57$ (s, 2H); 3.12 (d, $J=7 \mathrm{~Hz}, 2 \mathrm{H}) ; 3.09$ (d, $J=6.5 \mathrm{~Hz}, 2 \mathrm{H}) ; 1.97$ - 2.04 (m, 1H); $1.89-1.95$ (m, 1H); 1.79 (oct., $J=7$ Hz, 1H); $1.22-1.38$ (m, 6H); 0.95 $(\mathrm{d}, J=6.5 \mathrm{~Hz}, 3 \mathrm{H}) ; 0.88(\mathrm{t}, J=7 \mathrm{~Hz}, 3 \mathrm{H}) ; 0.86(\mathrm{~d}, J=7 \mathrm{~Hz}, 3 \mathrm{H}) .{ }^{13} \mathrm{C} \mathrm{NMR}(125 \mathrm{MHz}$, $\left.\mathrm{CDCl}_{3}\right) \delta 144.51,139.70,136.22,129.16,128.37,127.04,124.66,117.67,82.42,58.28$, 57.14, 50.91, 32.59, 31.71, 29.89, 28.45, 22.66, 20.14, 18.07, 14.29. IR (thin film NaCl): 3423, 3065, 3028, 2956, 2930, 2870, 1643, 1495, 1455, 1366, 1255, 1118, 1073, 1012. HRMS (ESI) $m / z 330.279\left[(\mathrm{M}+\mathrm{Na})^{+}\right.$; calcd for $\mathrm{C}_{22} \mathrm{H}_{35} \mathrm{NO}$ : 330.279].

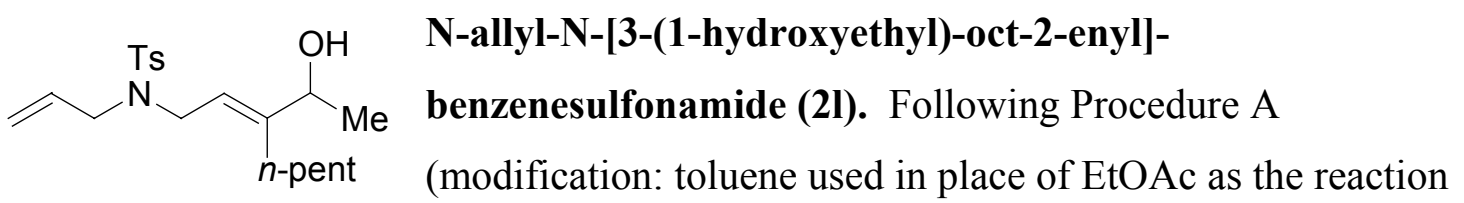

solvent), reductive coupling of acetaldehyde ( $200 \mu \mathrm{L}, 3.6 \mathrm{mmol})$ and $1 \mathbf{i}(160 \mathrm{mg}, 0.5$ mmol) afforded the title compound as a clear oil (125 mg, 68\% yield, $>95: 5$ regioselectivity). $\mathrm{R}_{f}=0.29$ (3:1 hexanes: ethyl acetate). ${ }^{1} \mathrm{H} \mathrm{NMR}\left(500 \mathrm{MHz}, \mathrm{CDCl}_{3}\right) \delta$ $7.71(\mathrm{~d}, J=8.5 \mathrm{~Hz}, 2 \mathrm{H}) ; 7.30(\mathrm{~d}, J=8.5 \mathrm{~Hz}, 2 \mathrm{H}) ; 5.64-5.73(\mathrm{~m}, 1 \mathrm{H}) ; 5.26(\mathrm{t}, J=7 \mathrm{~Hz}$, 
1H); $5.14-5.18(\mathrm{~m}, 2 \mathrm{H}) ; 4.16(\mathrm{q}, J=6.5 \mathrm{~Hz}, 1 \mathrm{H}) ; 3.86(\mathrm{~d}, J=6.5 \mathrm{~Hz}, 2 \mathrm{H}) ; 3.79-3.81$ (m, 2H); 2.44 (s, 3H); $2.02-2.08$ (m, 1H); $1.89-1.96$ (m, 1H); $1.22-1.36(\mathrm{~m}, 6 \mathrm{H})$; $1.20(\mathrm{~d}, J=6.5 \mathrm{~Hz}, 3 \mathrm{H}) ; 0.89(\mathrm{t}, J=7 \mathrm{~Hz}, 3 \mathrm{H}) .{ }^{13} \mathrm{C} \mathrm{NMR}\left(125 \mathrm{MHz}, \mathrm{CDCl}_{3}\right) \delta 148.02$, 143.44, 137.74, 133.39, 129.83, 127.45, 118.98, 118.87, 71.34, 49.90, 44.17, 32.36, 29.71, 27.98, 22.64, 22.40, 21.73, 14.24. IR (thin film NaCl): 3521, 2957, 2931, 2870 , 1644, 1598, 1495, 1446, 1418, 1402, 1343, 1305, 1289, 1264, 1213, 1159, 1119, 1092, 1059. HRMS (ESI) $m / z 388.192\left[(\mathrm{M}+\mathrm{Na})^{+}\right.$; calcd for $\left.\mathrm{C}_{20} \mathrm{H}_{31} \mathrm{NO}_{3} \mathrm{~S}: 388.192\right]$.

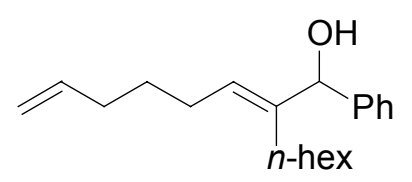

2-Hexyl-1-phenyl-octa-2,7-dien-1-ol (6). Following Procedure A (modification: toluene used in place of EtOAc as the reaction solvent), reductive coupling of benzaldehyde (106 $\mu \mathrm{L}, 1 \mathrm{mmol})$

and $1 \mathbf{c}(89 \mathrm{mg}, 0.5 \mathrm{mmol})$ proceeded slowly and only minimal conversion was observed after $15 \mathrm{~h}$. The reaction was allowed to stir at $23{ }^{\circ} \mathrm{C}$ for an additional $25 \mathrm{~h}$ prior to quenching. Flash chromatography on silica gel afforded the title compound as a clear oil (37 mg, 26\% yield, $>95: 5$ regioselectivity). $\mathrm{R}_{f}=0.29$ (10:1 hexanes: ethyl acetate). ${ }^{1} \mathrm{H}$ NMR (500 MHz, $\left.\mathrm{CDCl}_{3}\right) \delta 7.32-7.38(\mathrm{~m}, 3 \mathrm{H}) ; 7.24-7.29(\mathrm{~m}, 2 \mathrm{H}) ; 5.79-5.88(\mathrm{~m}$, $1 \mathrm{H}) ; 5.62$ (t, $J=7 \mathrm{~Hz}, 1 \mathrm{H}) ; 5.17$ (s, $1 \mathrm{H}) ; 5.02$ (dq, $J=17,1.5 \mathrm{~Hz}, 1 \mathrm{H}) ; 4.95-4.99$ (m, $1 \mathrm{H}$ ); $2.06-2.15$ (m, 4H); $1.95-2.02(\mathrm{~m}, 1 \mathrm{H}) ; 1.78-1.86(\mathrm{~m}, 1 \mathrm{H}) ; 1.51$ (quin., $J=7.5$ $\mathrm{Hz}, 2 \mathrm{H}) ; 1.15-1.30(\mathrm{~m}, 8 \mathrm{H}) ; 0.86(\mathrm{t}, J=7 \mathrm{~Hz}, 3 \mathrm{H}) .{ }^{13} \mathrm{C} \mathrm{NMR}\left(125 \mathrm{MHz}, \mathrm{CDCl}_{3}\right) \delta$ 142.94, 141.86, 138.97, 128.43, 127.58, 126.90, 126.77, 114.78, 78.32, 33.70, 31.76, $29.83,29.65,29.24,28.04,27.26,22.78,14.29$. IR (thin film NaCl): 3373, 3063, 3029, 2955, 2928, 2858, 1641, 1493, 1454, 1378, 1190, 1014, 911, 700. HRMS (ESI) $\mathrm{m} / \mathrm{z}$ $309.220\left[(\mathrm{M}+\mathrm{Na})^{+}\right.$; calcd for $\left.\mathrm{C}_{20} \mathrm{H}_{30} \mathrm{O}: 309.219\right]$.

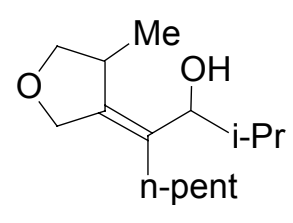

\section{2-Methyl-4-(4-methyl-dihydro-furan-3-ylidene)-nonan-3-ol (7).}

Following Procedure B on half-scale, Ni(cod $)_{2}(7 \mathrm{mg}, 25 \mu \mathrm{mol})$,

$\operatorname{PCyp}_{3}(14 \mu \mathrm{L}, 50 \mu \mathrm{mol})$, ethyl acetate $(0.25 \mathrm{~mL})$ and $\mathrm{Et}_{3} \mathrm{~B}(75 \mu \mathrm{L}$,

$0.50 \mathrm{mmol}$ ) were combined under argon and the resulting solution was cooled to $0{ }^{\circ} \mathrm{C}$. Isobutyraldehyde $(45 \mu \mathrm{L}, 0.5 \mathrm{mmol})$ was added dropwise via microsyringe, followed by $1 \mathrm{~g}(42 \mathrm{mg}, 0.25 \mathrm{mmol})$. The reaction was allowed to gradually warm to room temperature and stir for $15 \mathrm{~h}$. Formation of an allylic alcohol of 
analogous structure to $\mathbf{3} \mathbf{c}$ was not observed. Rather, purification by flash chromatography on silica gel (hexanes: ethyl acetate; 10:1 to 5:1) provided carbocyclization product 7 as a clear oil ( $16 \mathrm{mg}, 27 \%$ yield, $>10: 1 \mathrm{dr}) . \mathrm{R}_{f}=0.52(3: 1$ hexanes: ethyl acetate). ${ }^{1} \mathrm{H}$ NMR $\left(500 \mathrm{MHz}, \mathrm{CDCl}_{3}\right) \delta 4.45(\mathrm{~d}, J=13.5 \mathrm{~Hz}, 1 \mathrm{H}) ; 4.28(\mathrm{~d}$, $J=13.5 \mathrm{~Hz}, 1 \mathrm{H}) ; 3.98$ (d, $J=9.5 \mathrm{~Hz}, 1 \mathrm{H}) ; 3.80(\mathrm{dd}, J=8,5 \mathrm{~Hz}, 1 \mathrm{H}) ; 3.70(\mathrm{~d}, J=9 \mathrm{~Hz}$, $1 \mathrm{H}) ; 2.90-2.98$ (m, 1H); $1.94-2.01$ (m, 1H); $1.81-1.90$ (m, 2H); $1.20-1.40$ (m, 6H); $1.13(\mathrm{~d}, J=7 \mathrm{~Hz}, 3 \mathrm{H}) ; 1.10(\mathrm{~d}, J=6.5 \mathrm{~Hz}, 3 \mathrm{H}) ; 0.90(\mathrm{t}, J=7 \mathrm{~Hz}, 3 \mathrm{H}) ; 0.81(\mathrm{~d}, J=6.5$ $\mathrm{Hz}, 3 \mathrm{H}) .{ }^{13} \mathrm{C} \mathrm{NMR}\left(125 \mathrm{MHz}, \mathrm{CDCl}_{3}\right) \delta 143.17,131.78,79.46,75.94,69.22,36.16$, $32.94,31.58,29.72,29.17,22.65,21.05,20.17,19.82,14.30$. IR (thin film $\mathrm{NaCl}$ ): 3443 , 2957, 2931, 2870, 1466, 1379, 1315, 1260, 1091, 1009. HRMS (ESI) m/z 263.199 [(M + $\mathrm{Na})^{+}$; calcd for $\mathrm{C}_{15} \mathrm{H}_{28} \mathrm{O}_{2}$ : 263.198].

\section{Structural confirmation of $2 \mathrm{c}$ via TBS protection and ozonolytic cleavage.}

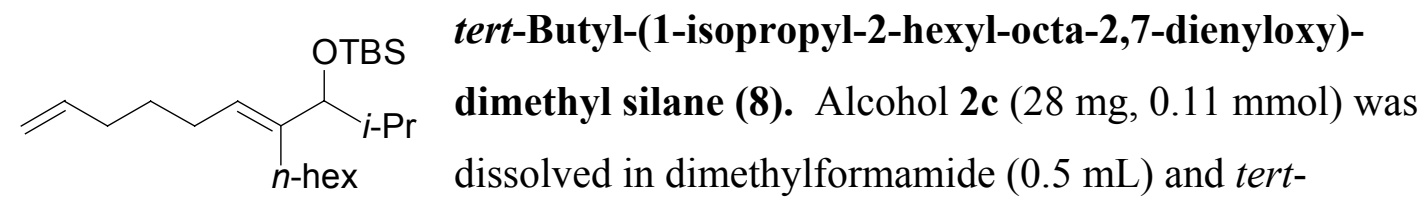

butyldimethylsilyl chloride ( $33 \mathrm{mg}, 0.22 \mathrm{mmol}$ ), imidazole ( $15 \mathrm{mg}, 0.22 \mathrm{mmol}$ ), and 4dimethylaminopyridine ( $27 \mathrm{mg}, 0.22 \mathrm{mmol}$ ) were added sequentially. The mixture was allowed to stir overnight, and was then quenched by addition of water $(2 \mathrm{~mL})$ and diethyl ether $(2 \mathrm{~mL})$. The organics were extracted with additional diethyl ether $(2 \times 2 \mathrm{~mL})$, dried over anhydrous $\mathrm{MgSO}_{4}$, and concentrated. Flash chromatography on silica gel (10:1 hexanes:ethyl acetate) afforded the title compound as a clear oil ( $25 \mathrm{mg}, 62 \%$ yield ( $95 \%$ BRSM)). $\mathrm{R}_{f}=0.67\left(10: 1\right.$ hexanes: ethyl acetate). ${ }^{1} \mathrm{H}$ NMR $\left(500 \mathrm{MHz}, \mathrm{CDCl}_{3}\right) \delta 5.79-$ $5.87(\mathrm{~m}, 1 \mathrm{H}) ; 5.26(\mathrm{t}, J=7 \mathrm{~Hz}, 1 \mathrm{H}) ; 4.99-5.04(\mathrm{~m}, 1 \mathrm{H}) ; 4.95-4.97$ (m, 1H); 3.60 (d, $J$ $=6.5 \mathrm{~Hz}, 1 \mathrm{H}) ; 2.01-2.10(\mathrm{~m}, 4 \mathrm{H}) ; 1.87-2.00(\mathrm{~m}, 2 \mathrm{H}) ; 1.69$ (oct., $J=6.5 \mathrm{~Hz}, 1 \mathrm{H}) ; 1.42$ -1.49 (m, 2H); $1.24-1.40(\mathrm{~m}, 8 \mathrm{H}) ; 0.90(\mathrm{~s}, 9 \mathrm{H}) ; 0.90$ (t, $J=7 \mathrm{~Hz}, 3 \mathrm{H}) ; 0.85$ (d, $J=6.5$ $\mathrm{Hz}, 3 \mathrm{H}) ; 0.80$ (d, $J=7 \mathrm{~Hz}, 3 \mathrm{H}) ; 0.02$ (s, 3H); -0.05 (s, 3H). ${ }^{13} \mathrm{C}$ NMR $(125 \mathrm{MHz}$, $\left.\mathrm{CDCl}_{3}\right) \delta 141.05,139.19,127.00,114.61,83.17,33.80,32.22,31.96,30.40,30.05,29.40$, $27.88,27.21,26.20,22.94,20.39,18.49,18.16,14.35,-3.95,-4.77$. IR (thin film $\mathrm{NaCl}$ ): 
2957, 2929, 2858, 1642, 1472, 1383, 1361, 1254, 1128, 1054. HRMS (ESI) $m / z 389.323$ $\left[(\mathrm{M}+\mathrm{Na})^{+}\right.$; calcd for $\mathrm{C}_{23} \mathrm{H}_{46} \mathrm{OSi}$ : 389.321].

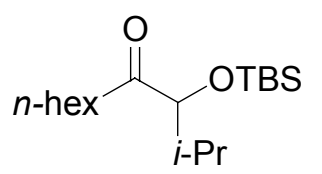
3-(tert-Butyl-dimethyl-silanoxy)-2-methyl-decan-4-one (9). tertButyldimethylsilyl ether 8 (17 mg, $46 \mu \mathrm{mol})$ was dissolved in dichloromethane $(2 \mathrm{~mL})$ and cooled to $-78{ }^{\circ} \mathrm{C}$. Ozone was then

bubbled through the solution until a blue color was observed $(<1 \mathrm{~min})$. The solution was purged with argon for $5 \mathrm{~min}$, and then triphenylphosphine ( $60 \mathrm{mg}, 0.23 \mathrm{mmol}$ ) was added. The mixture was allowed to warm gradually to ambient temperature and stir overnight. Concentration of the solution and purification via flash chromatography on silica gel (1:1 hexanes:benzene) provided the title compound as a clear oil ( $7.5 \mathrm{mg}, 54 \%$ yield). $\mathrm{R}_{f}=0.60$ (1:1 hexanes: benzene). ${ }^{1} \mathrm{H}$ NMR $\left(500 \mathrm{MHz}, \mathrm{CDCl}_{3}\right) \delta 3.72(\mathrm{~d}, J=5.5$ $\mathrm{Hz}, 1 \mathrm{H}) ; 2.51-2.59$ (m, 1H); $2.41-2.49$ (m, 1H); 1.93 (oct., $J=6.5 \mathrm{~Hz}, 1 \mathrm{H}) ; 1.51$ 1.57 (m, 2H); $1.24-1.34$ (m, 8H); 0.94 (s, 9H); $0.86-0.90$ (m, 9H); 0.05 (s, 3H); 0.02 (s, 3H). ${ }^{13} \mathrm{C}$ NMR $\left(125 \mathrm{MHz}, \mathrm{CDCl}_{3}\right) \delta 214.27,83.90,38.05,32.82,31.90,29.24,25.99$, 23.23, 22.74, 19.17, 18.36, 17.71, 14.27, -4.57, -4.84. IR (thin film NaCl): 2958, 2930, 2858, 1715, 1471, 1436, 1406, 1388, 1363, 1253, 1182, 1120, 1090, 1071. HRMS (ESI) $m / z 323.236\left[(\mathrm{M}+\mathrm{Na})^{+}\right.$; calcd for $\left.\mathrm{C}_{17} \mathrm{H}_{36} \mathrm{O}_{2} \mathrm{Si}: 323.238\right]$.

\section{Structural confirmation of $3 \mathrm{c}$ via TBS protection and ozonolytic cleavage.}

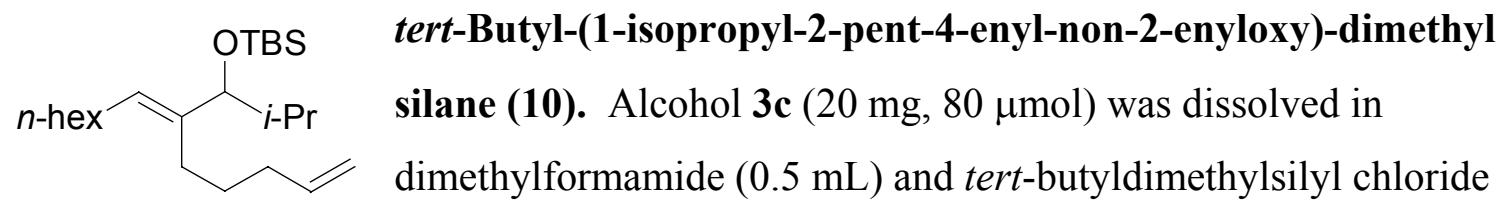

(24 mg, $0.16 \mathrm{mmol}$ ), imidazole (11 mg, $0.16 \mathrm{mmol}$ ), and 4-dimethylaminopyridine (20

$\mathrm{mg}, 0.16 \mathrm{mmol}$ ) were added sequentially. The mixture was allowed to stir overnight, and was then quenched by addition of water $(2 \mathrm{~mL})$ and diethyl ether $(2 \mathrm{~mL})$. The organics were extracted with additional diethyl ether $(2 \times 2 \mathrm{~mL})$, dried over anhydrous $\mathrm{MgSO}_{4}$, and concentrated. Flash chromatography on silica gel (hexanes) afforded the title compound as a clear oil ( $13 \mathrm{mg}, 45 \%$ yield $(91 \% \mathrm{BRSM})$ ). $\mathrm{R}_{f}=0.55$ (hexanes). ${ }^{1} \mathrm{H}$ NMR (500 MHz, $\left.\mathrm{CDCl}_{3}\right) \delta 5.79-5.87(\mathrm{~m}, 1 \mathrm{H}) ; 5.27(\mathrm{t}, \mathrm{J}=7 \mathrm{~Hz}, 1 \mathrm{H}) ; 5.00-5.04(\mathrm{~m}$, 
1H); $4.95-4.97$ (m, 1H); 3.59 (d, J = 7 Hz, 1H); $1.92-2.09$ (m, 6H); 1.69 (oct., J = 7 $\mathrm{Hz}, 1 \mathrm{H}) ; 1.44-1.52$ (m, 2H); $1.24-1.38$ (m, 8H); 0.90 (s, 9H); 0.89 (t, J = 7 Hz, 3H); $0.86(\mathrm{~d}, \mathrm{~J}=7 \mathrm{~Hz}, 3 \mathrm{H}) ; 0.79$ (d, J = 7 Hz, 3H); 0.02 (s, 3H); -0.05 (s, 3H). ${ }^{13} \mathrm{C}$ NMR (125 $\left.\mathrm{MHz}, \mathrm{CDCl}_{3}\right) \delta 140.24,139.07,127.98,114.65,83.40,34.79,32.26,32.03,30.02,29.36$, $29.29,27.75,27.26,26.19,22.89,20.32,18.48,18.31,14.33,-3.97,-4.78$. IR (thin film $\mathrm{NaCl}): 2957,2929,2857,1642,1472,1383,1361,1251,1128,1054$. HRMS (ESI) $\mathrm{m} / \mathrm{z}$ $389.320\left[(\mathrm{M}+\mathrm{Na})^{+}\right.$; calcd for $\left.\mathrm{C}_{23} \mathrm{H}_{46} \mathrm{OSi}: 389.321\right]$.

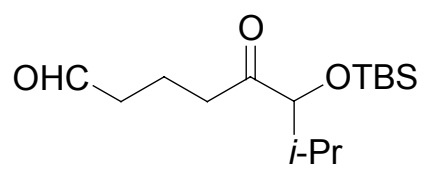

\section{6-(tert-Butyl-dimethyl-silanyloxy)-7-methyl-5-oxo-octanal}

(11). tert-Butyldimethylsilyl ether $\mathbf{1 0}$ (19 mg, $52 \mu \mathrm{mol})$ was dissolved in dichloromethane $(2 \mathrm{~mL})$ and cooled to $-78^{\circ} \mathrm{C}$.

Ozone was then bubbled through the solution until a blue color was observed $(<1 \mathrm{~min})$. The solution was purged with argon for $5 \mathrm{~min}$, and then triphenylphosphine (68 $\mathrm{mg}, 0.26$ mmol) was added. The mixture was allowed to warm gradually to ambient temperature and stir overnight. Concentration of the solution and purification via flash chromatography on silica gel (10:1 hexanes:ethyl acetate) afforded the title compound as a clear oil ( $12 \mathrm{mg}, 81 \%$ yield). $\mathrm{R}_{f}=0.30$ (10:1 hexanes: ethyl acetate). ${ }^{1} \mathrm{H}$ NMR (500 $\left.\mathrm{MHz}, \mathrm{CDCl}_{3}\right) \delta 9.77(\mathrm{t}, \mathrm{J}=1.5 \mathrm{~Hz}, 1 \mathrm{H}) ; 3.73(\mathrm{~d}, \mathrm{~J}=5.5 \mathrm{~Hz}, 1 \mathrm{H}) ; 2.62-2.68(\mathrm{~m}, 1 \mathrm{H})$; $2.47-2.55$ (m, 2H); $1.86-1.95$ (m, 3H); 0.93 (s, 9H); 0.89 (d, J = $6.5 \mathrm{~Hz}, 3 \mathrm{H}) ; 0.88$ (d, J $=7 \mathrm{~Hz}, 3 \mathrm{H}) ; 0.05(\mathrm{~s}, 3 \mathrm{H}) ; 0.01(\mathrm{~s}, 3 \mathrm{H}) .{ }^{13} \mathrm{C} \mathrm{NMR}\left(125 \mathrm{MHz}, \mathrm{CDCl}_{3}\right) \delta 213.36,202.17$, 83.73, 43.32, 36.94, 32.96, 25.97, 19.06, 18.32, 17.71, 15.76, -4.57, -4.83. IR (thin film $\mathrm{NaCl}):$ 2959, 2932, 2859, 2716, 1726, 1472, 1389, 1366, 1254, 1183, 1088.

\section{References}

${ }^{1}$ Arduengo, III., Anthony J. Preparation of 1,3-disubstituted imidazolium salts. U. S. Patent 5,182,405, January 26, 1993.

${ }^{2}$ Still, W. C.; Kahn, M.; Mitra, A. J. Org. Chem. 1978, 43, 2923 - 2925.

${ }^{3}$ Yamaguchi, R.; Kawasaki, H.; Yoshitome, T.; Kawanisi, M. Chem. Lett. 1982, 1485 1486.

${ }^{4}$ Eckhardt, M.; Fu, G. C. J. Am. Chem. Soc. 2003, 125, $13642-13643$.

${ }^{5}$ Hara, S.; Satoh, Y.; Suzuki, A. Chem. Lett. 1982, $1289-1290$.

${ }^{6}$ Urabe, H.; Sato, F. J. Am. Chem. Soc. 1999, 121, $1245-1255$.

${ }^{7}$ Liu, Y.; Xi, C.; Hara, R.; Nakajima, K.; Yamazaki, A.; Kotora, M.; Takahashi, T. J. Org. Chem. 2000, 65, $6951-6957$. 
${ }^{8}$ Naruse, M.; Utimoto, K.; Nozaki, H. Tetrahedron 1974, 30, 2159 - 2163.

${ }^{9}$ Araki, Y.; Konoike, T. J. Org. Chem. 1997, 62, $5299-5309$.

${ }^{10}$ Zhao, Z.; Ding, Y.; Zhao, G. J. Org. Chem. 1998, 63, $9285-9291$. 


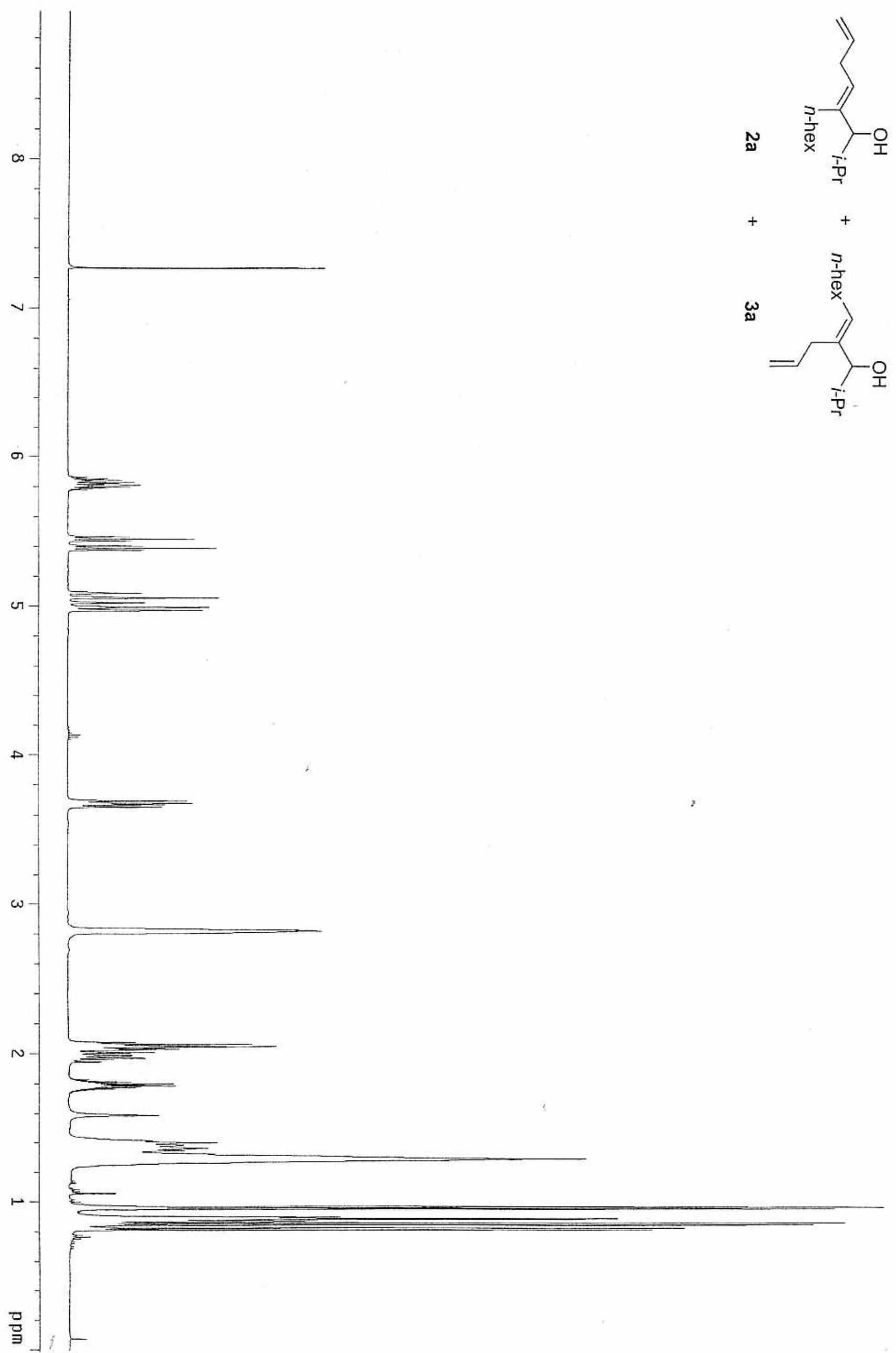




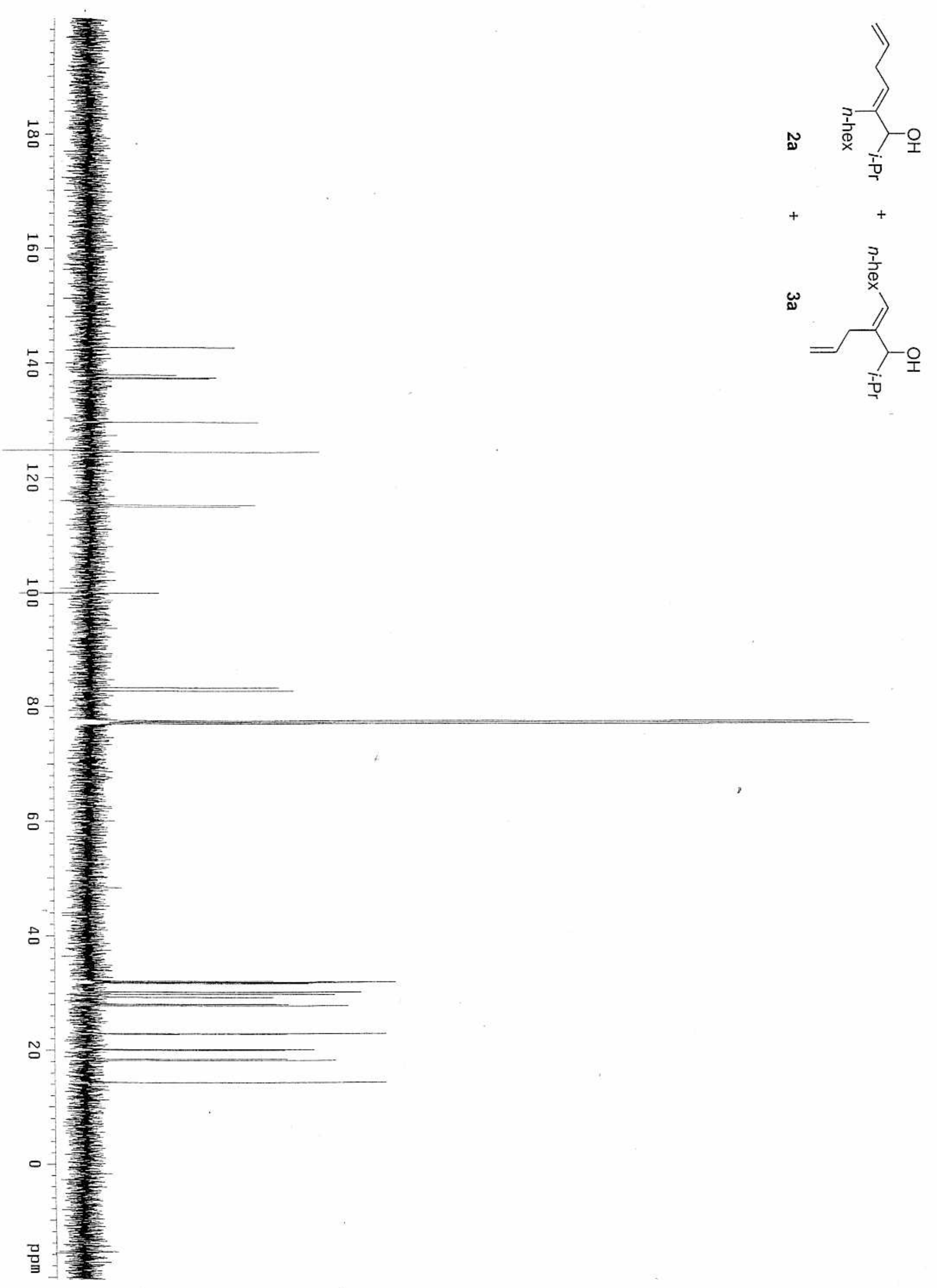




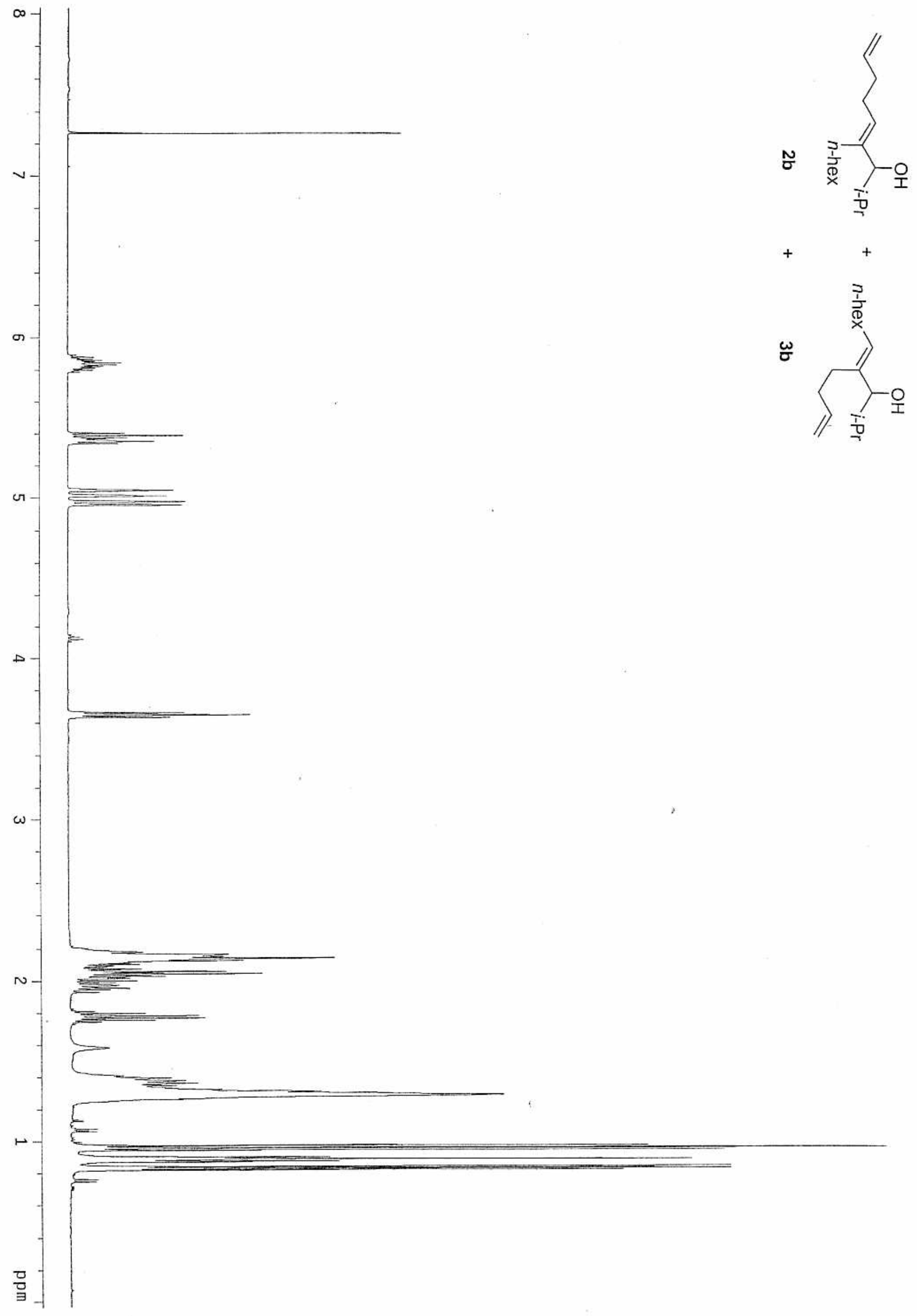




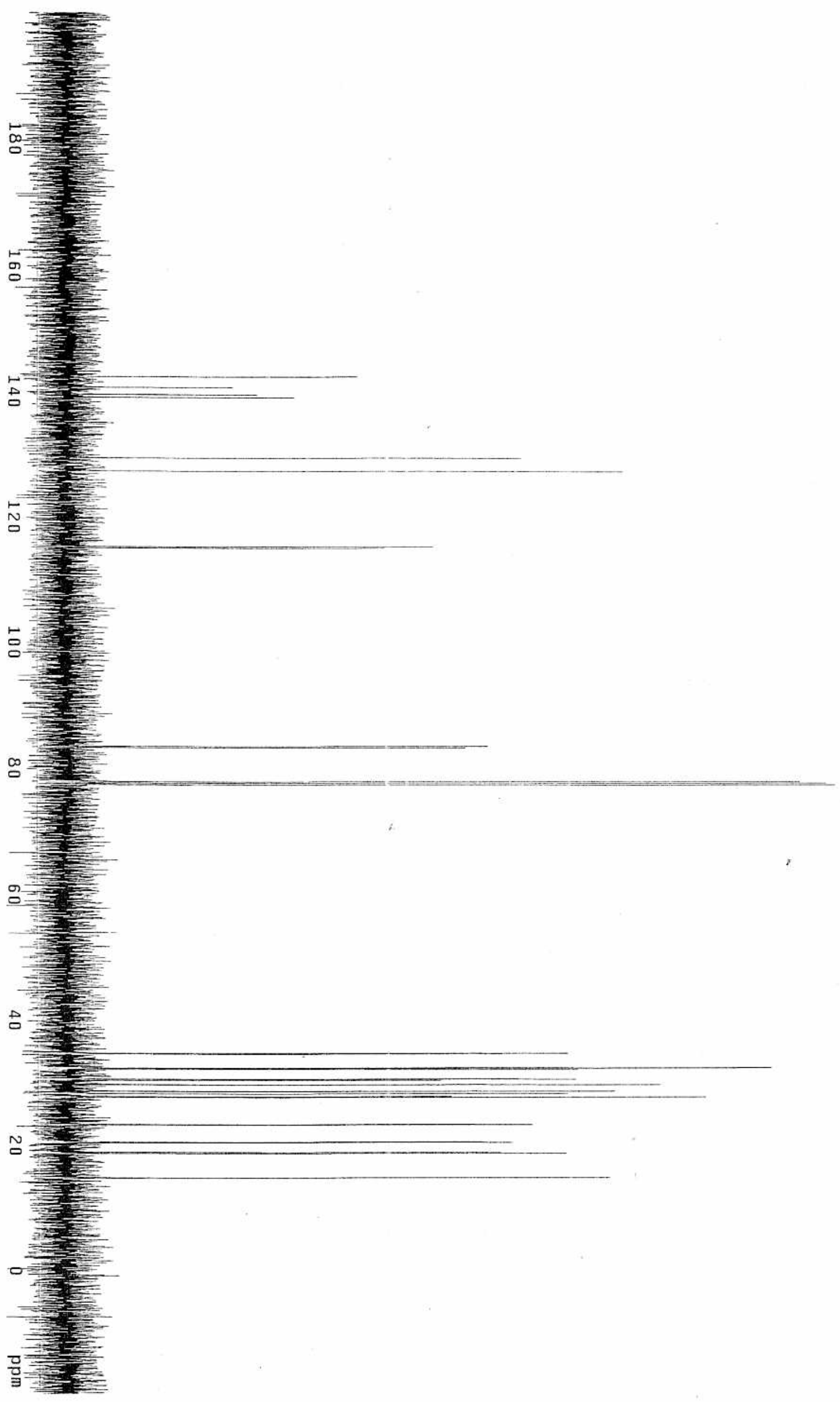




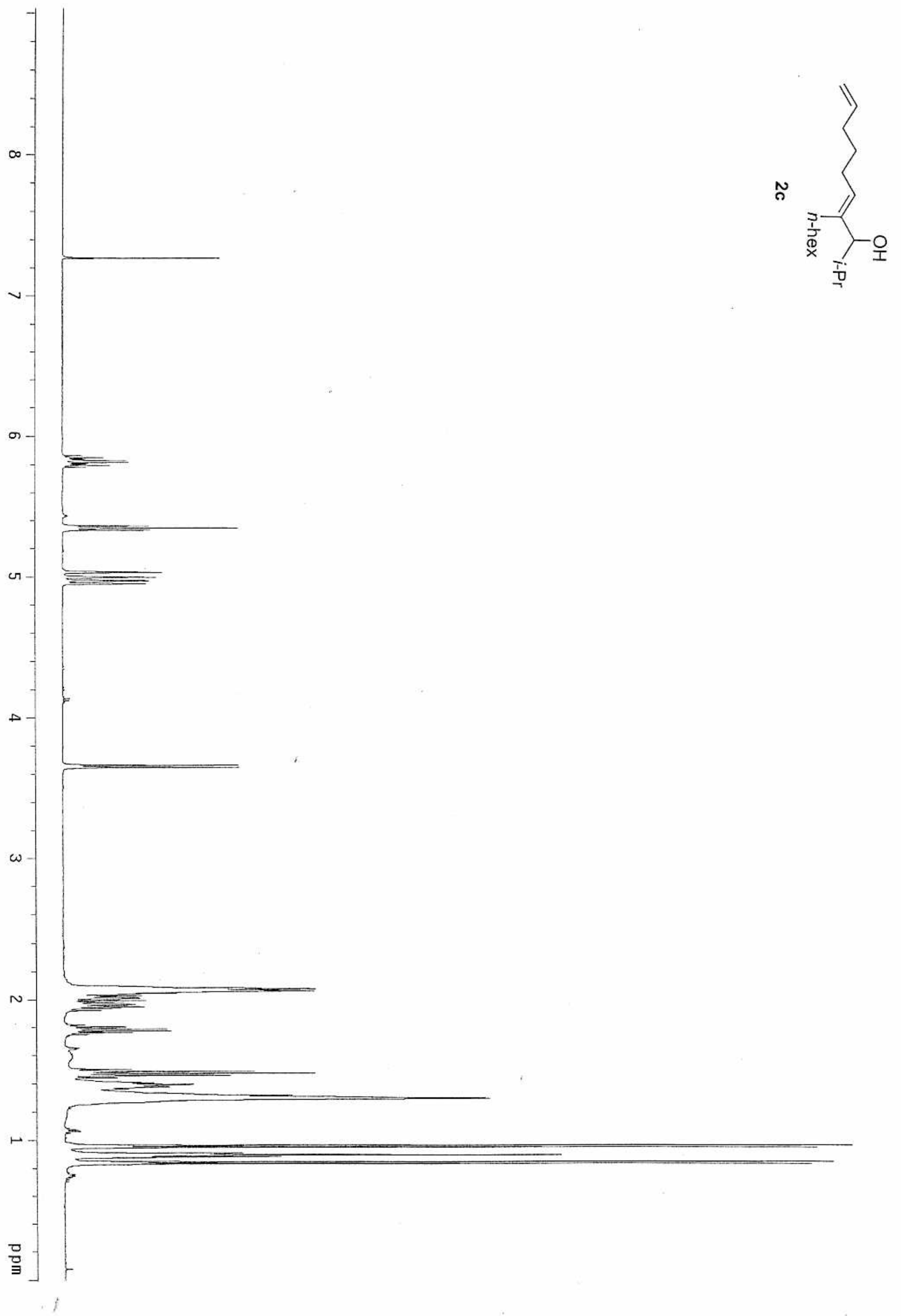




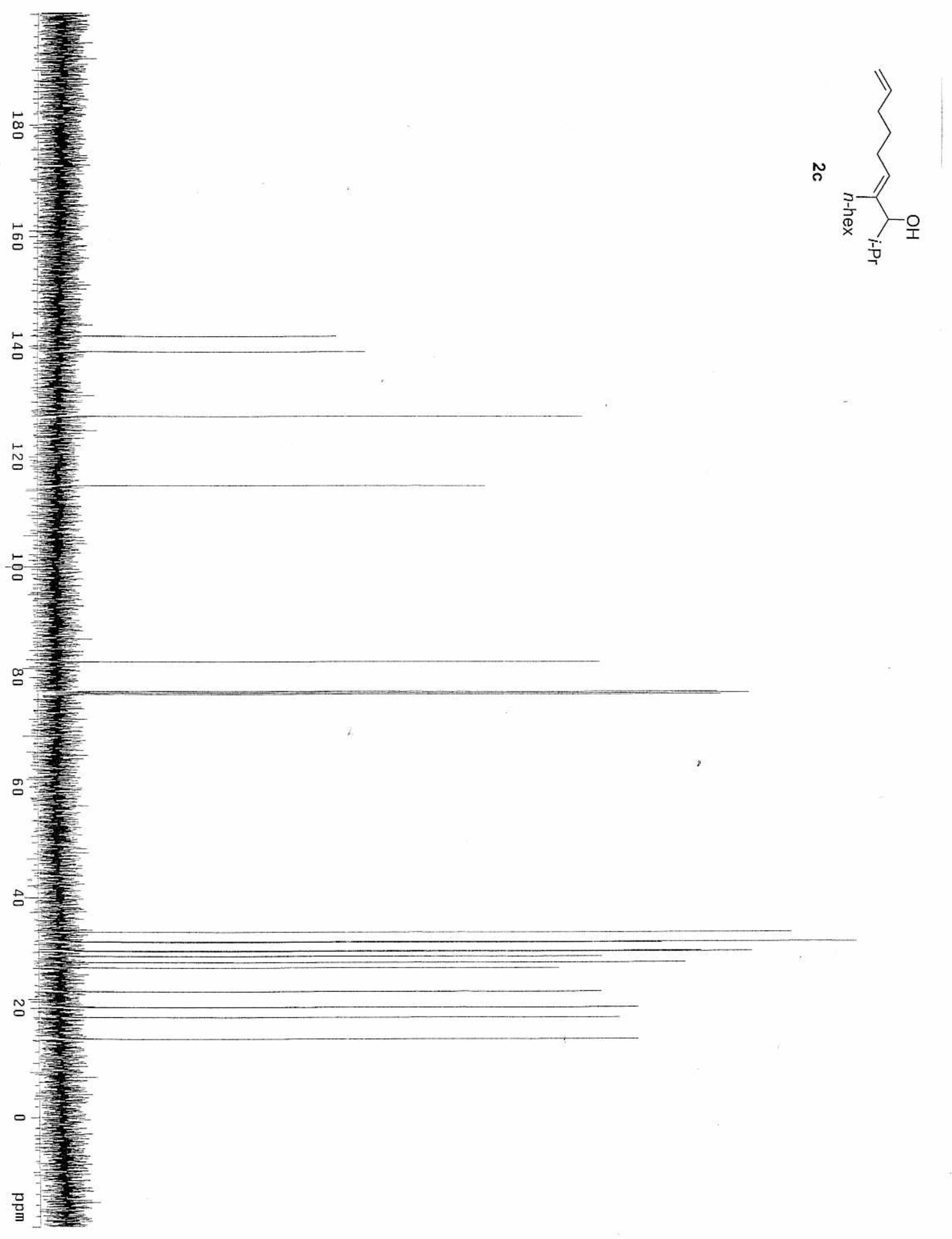




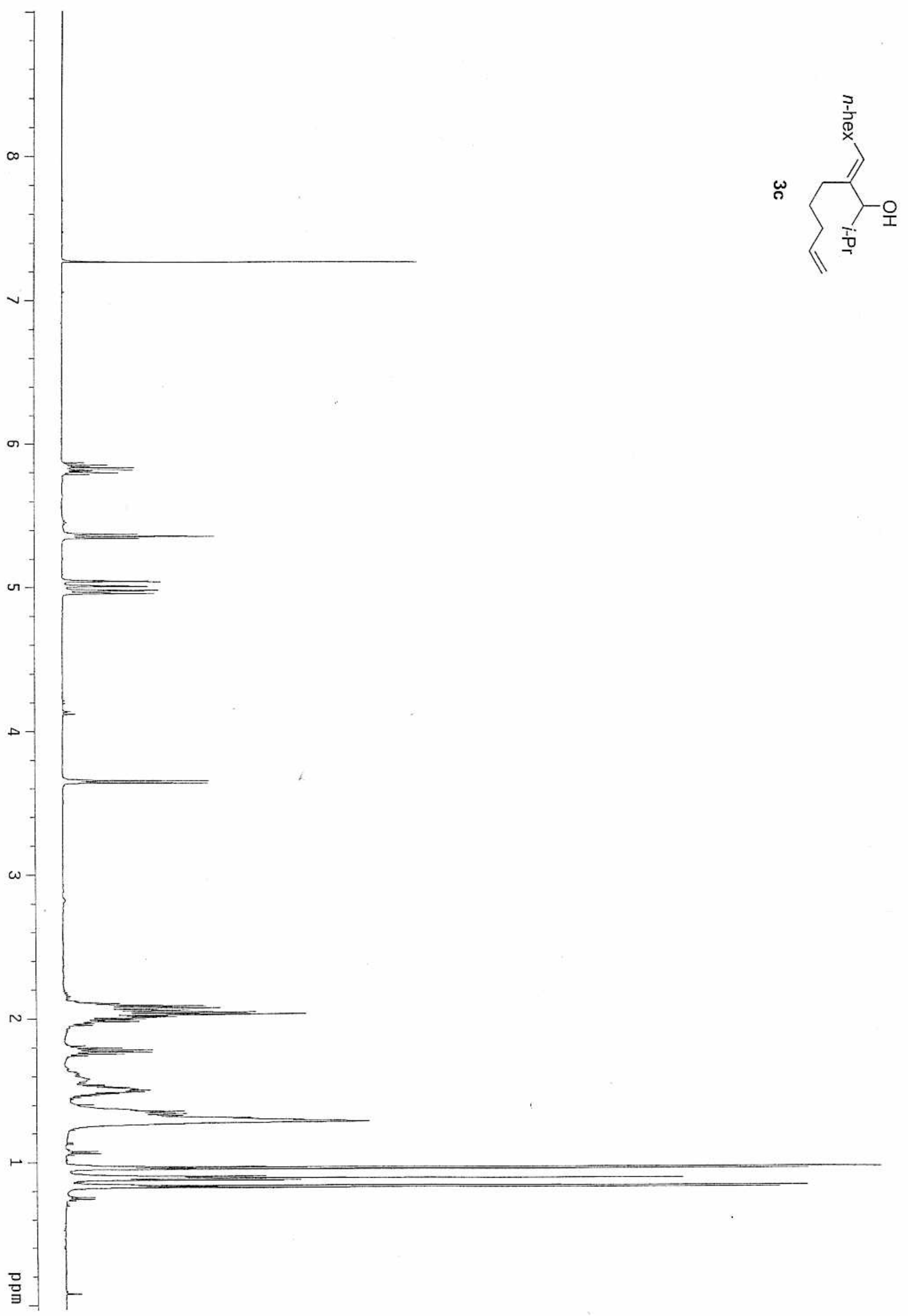




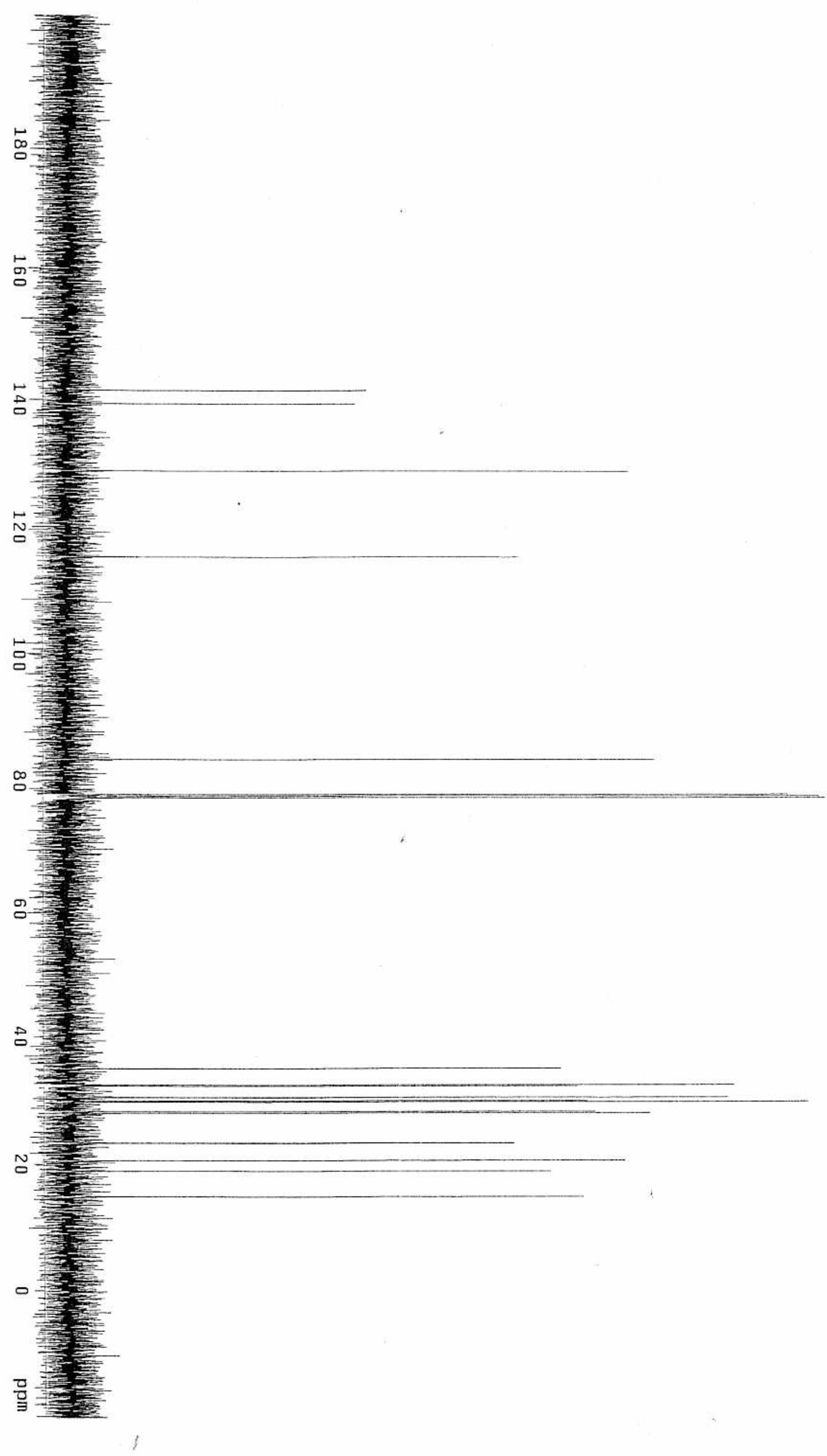




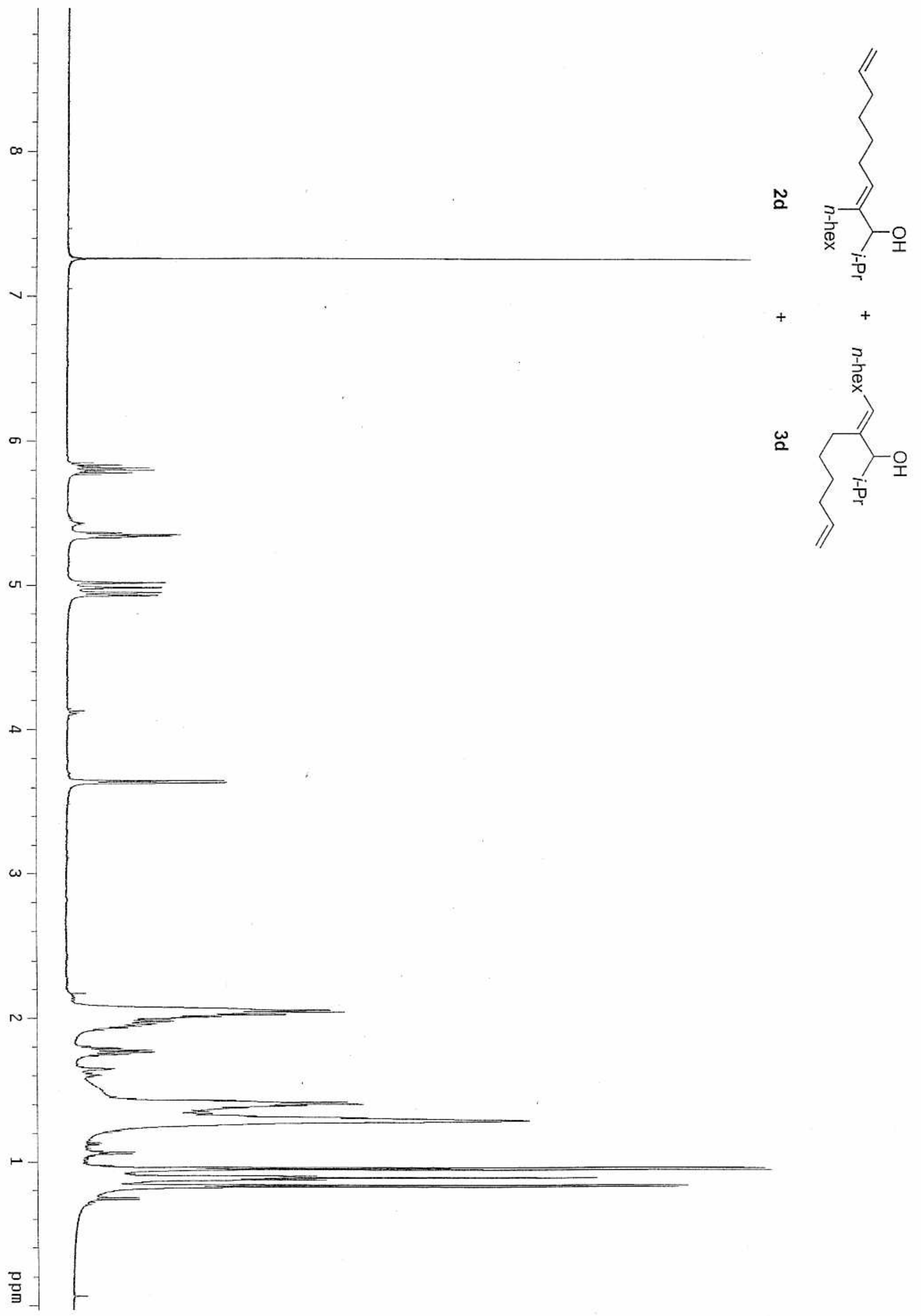




$$
t
$$




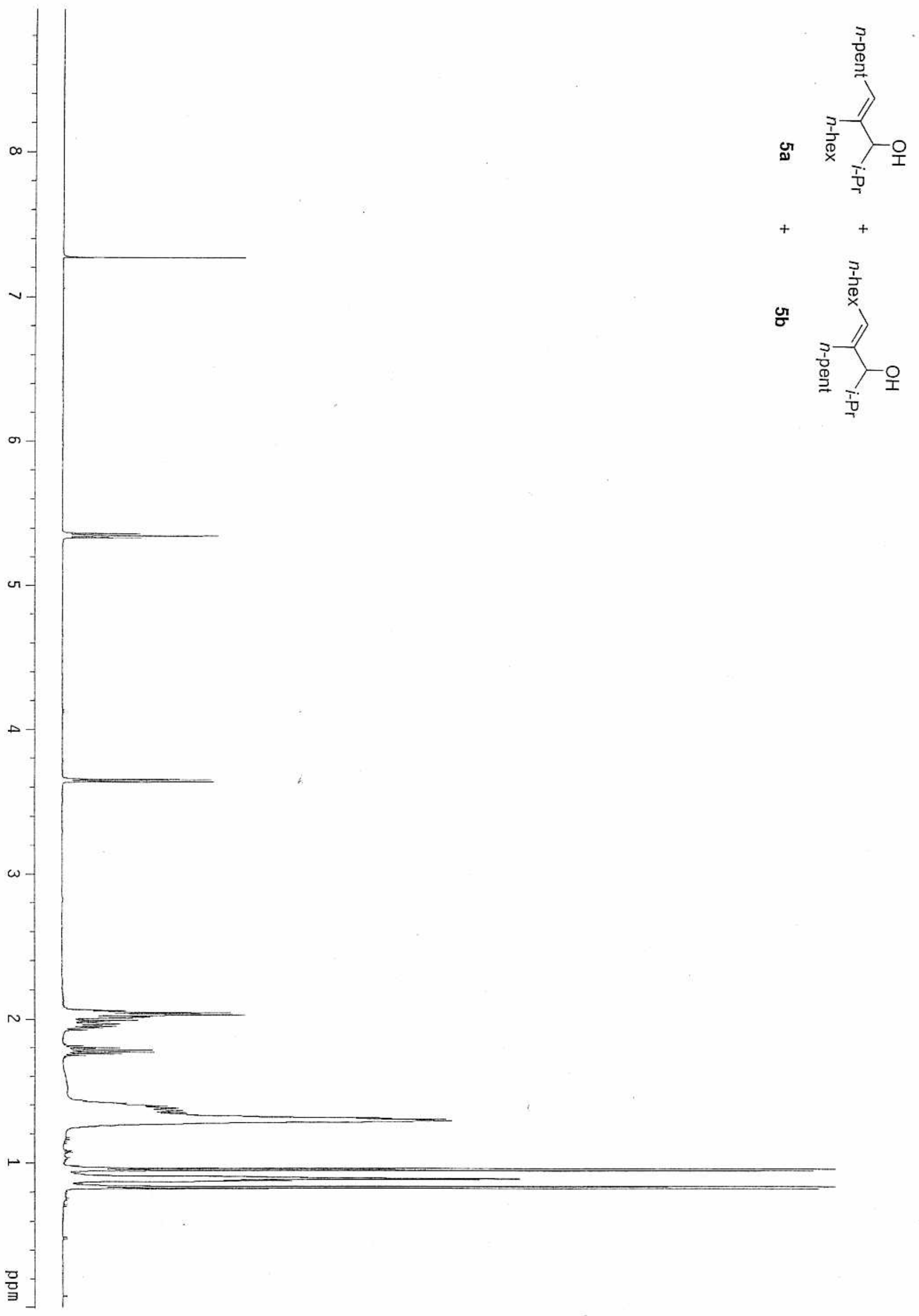




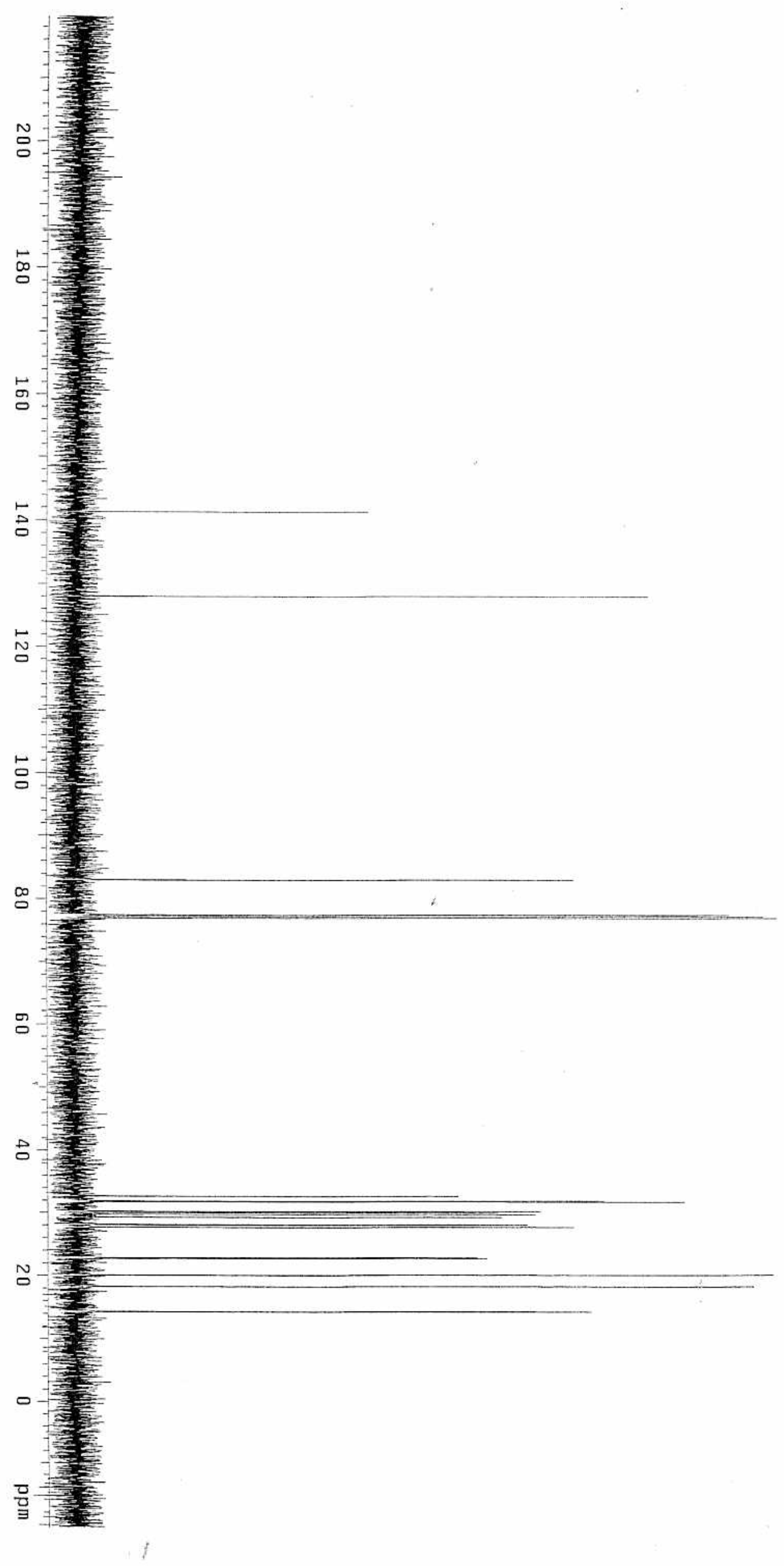




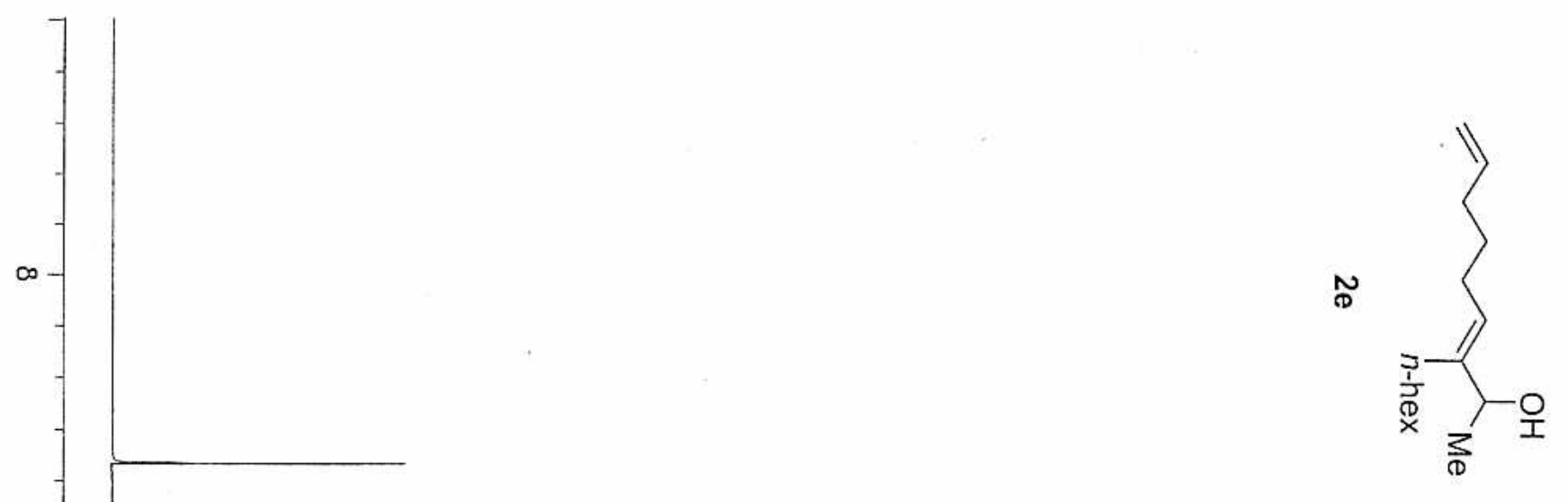




$$
\mid
$$




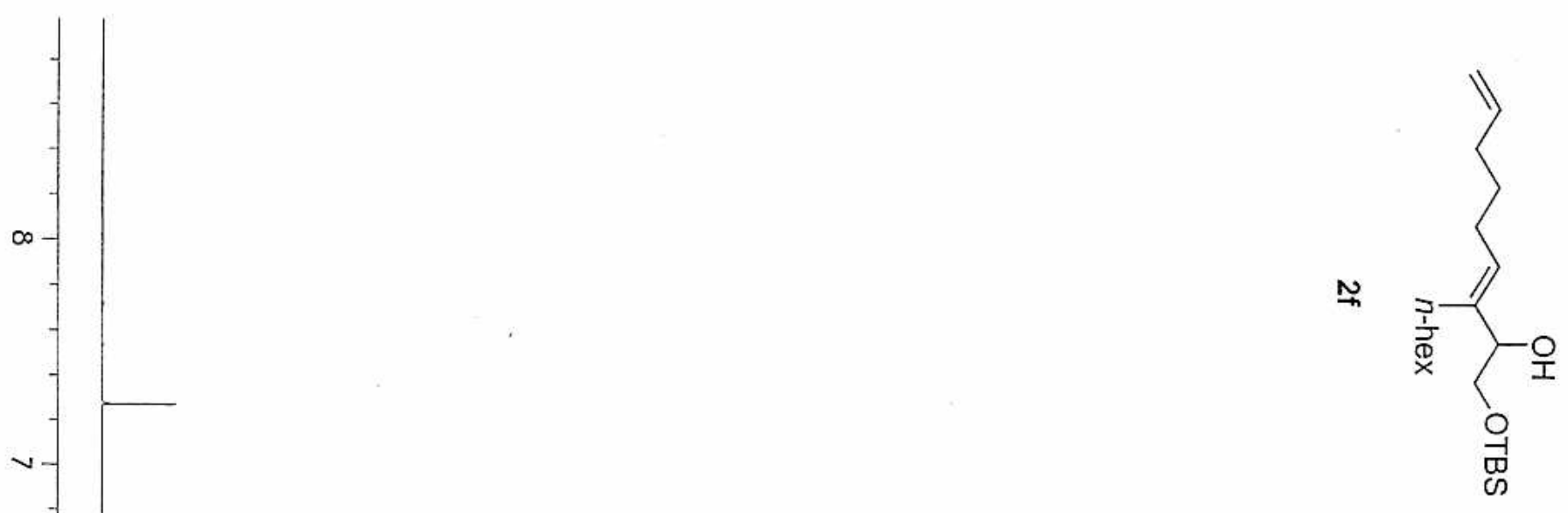

क
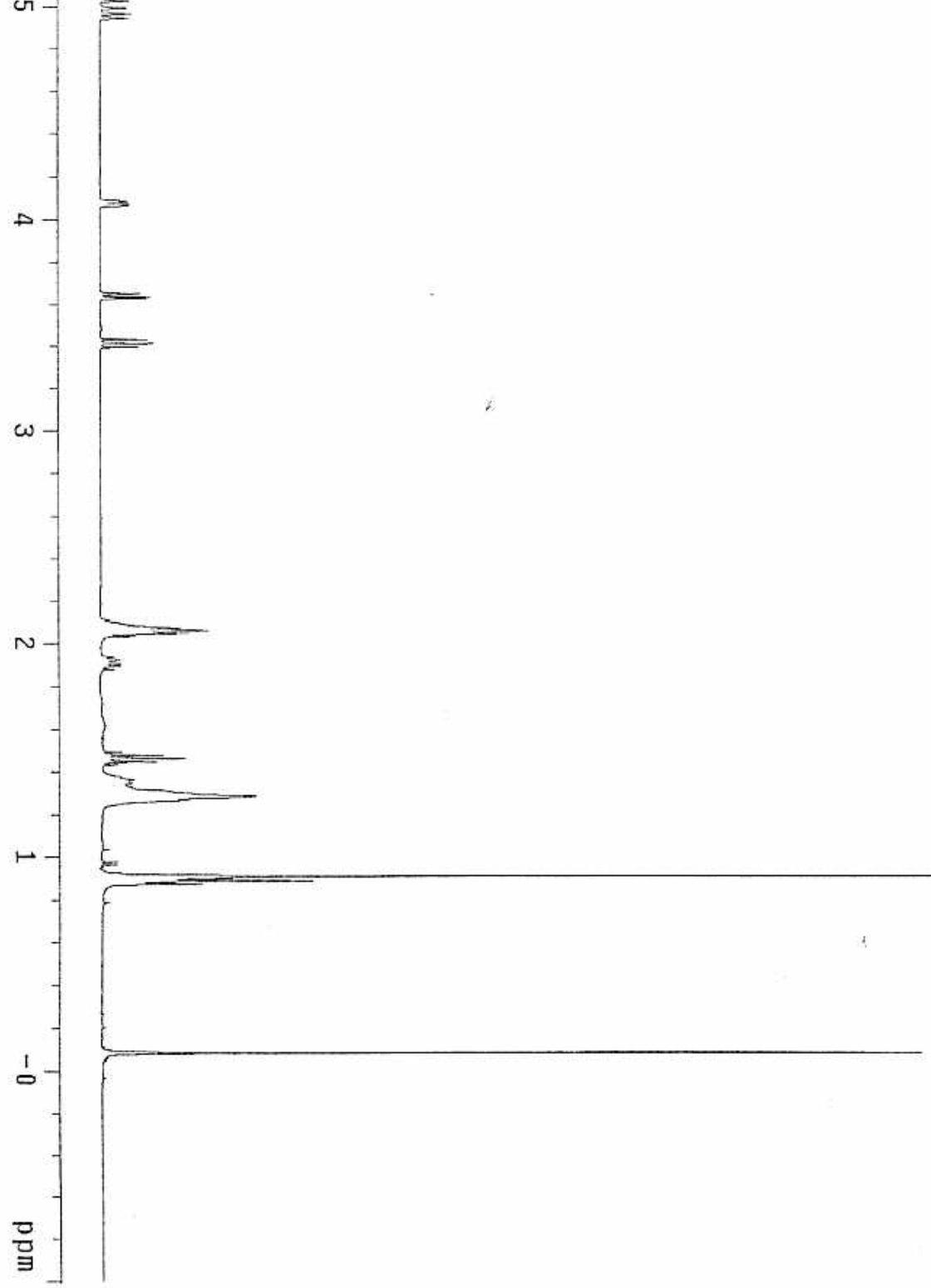


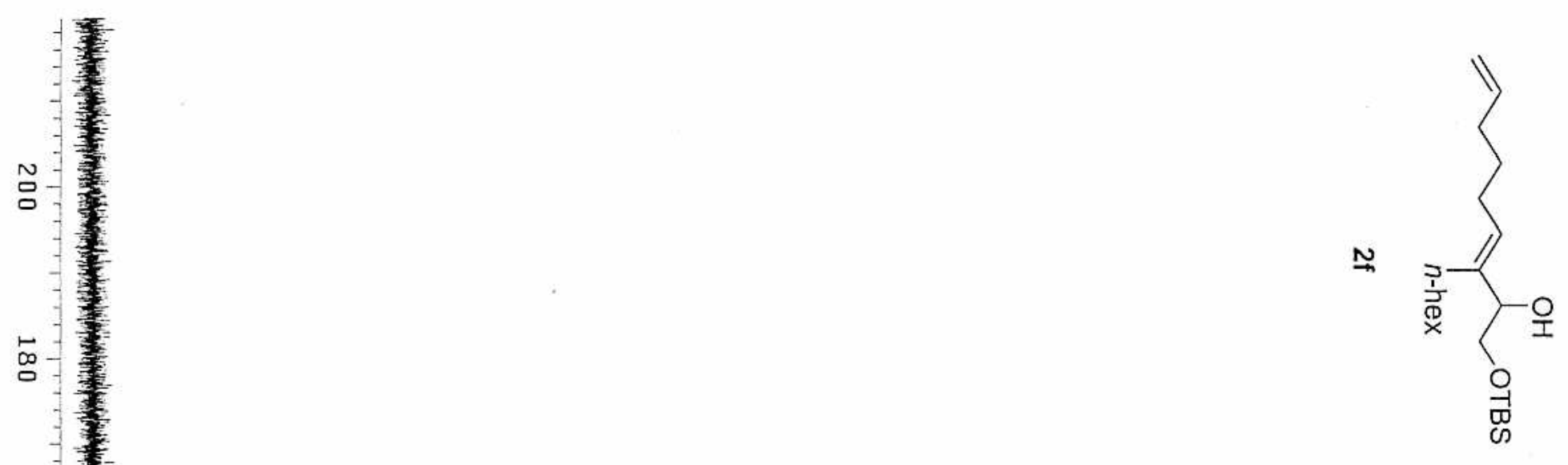




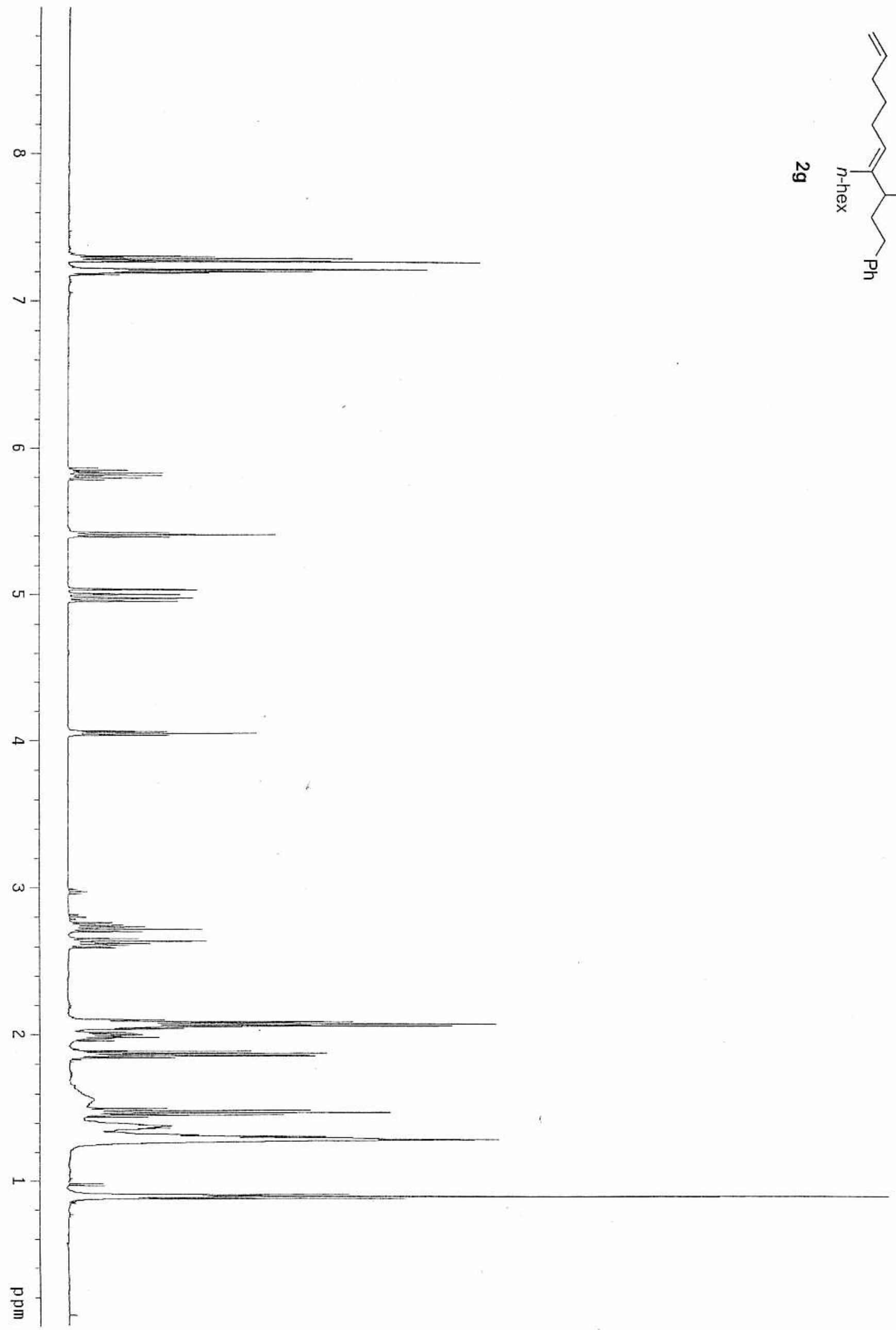




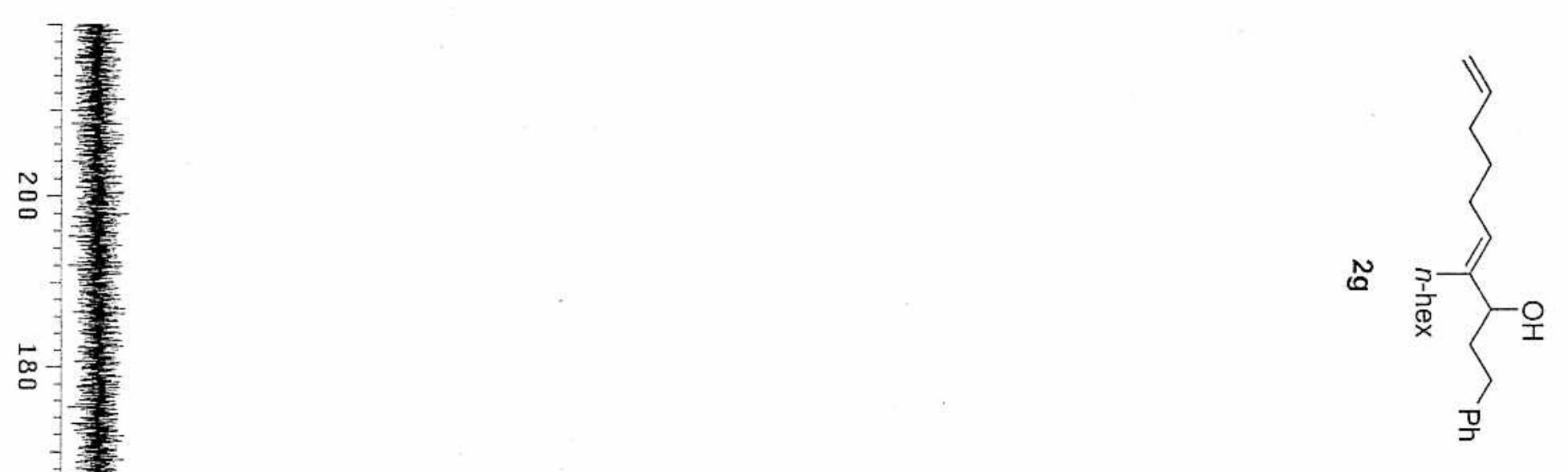

$\stackrel{b}{D}$

므

-

ํ.

-

음

$\infty$

-

9

? 


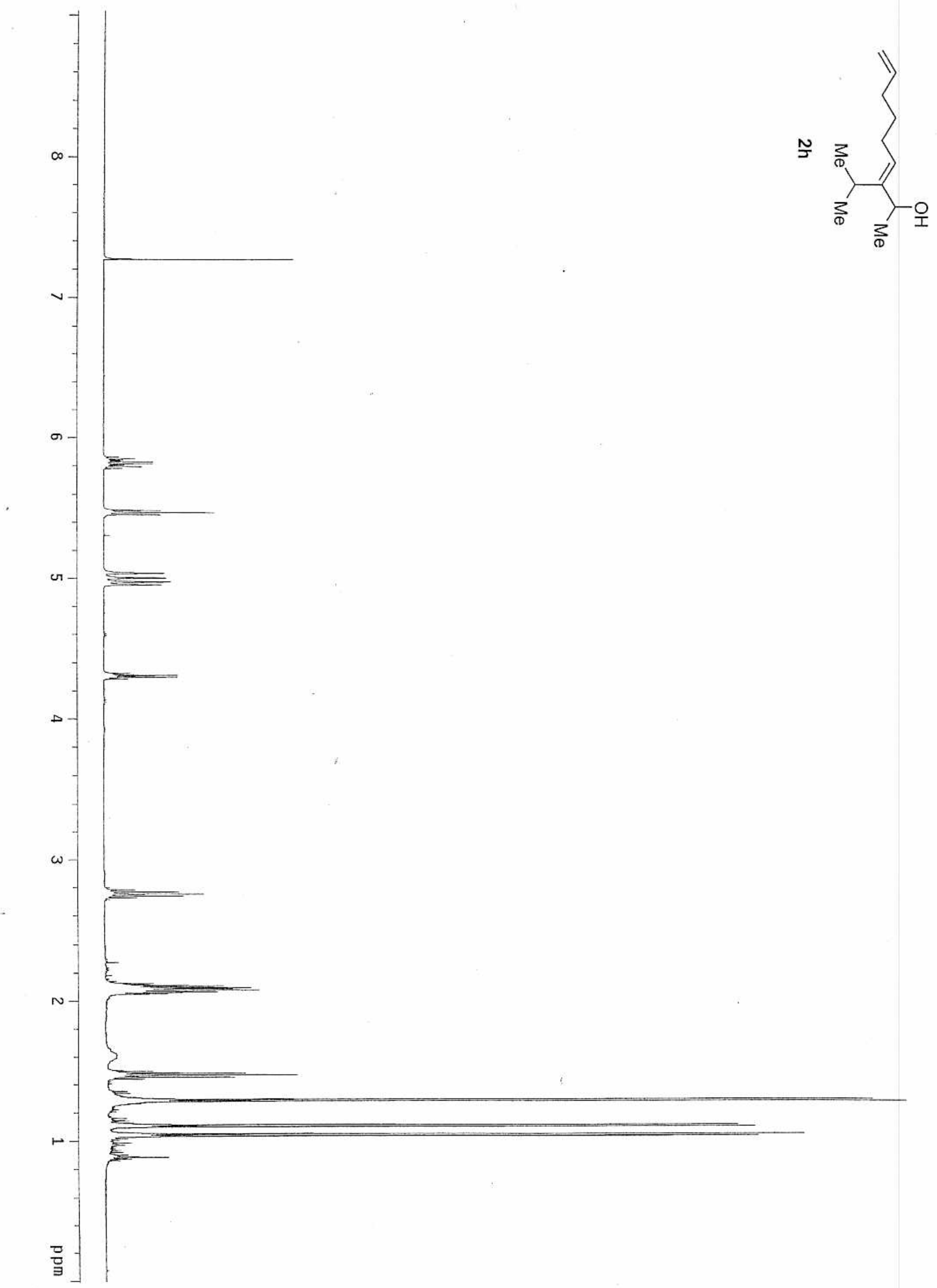



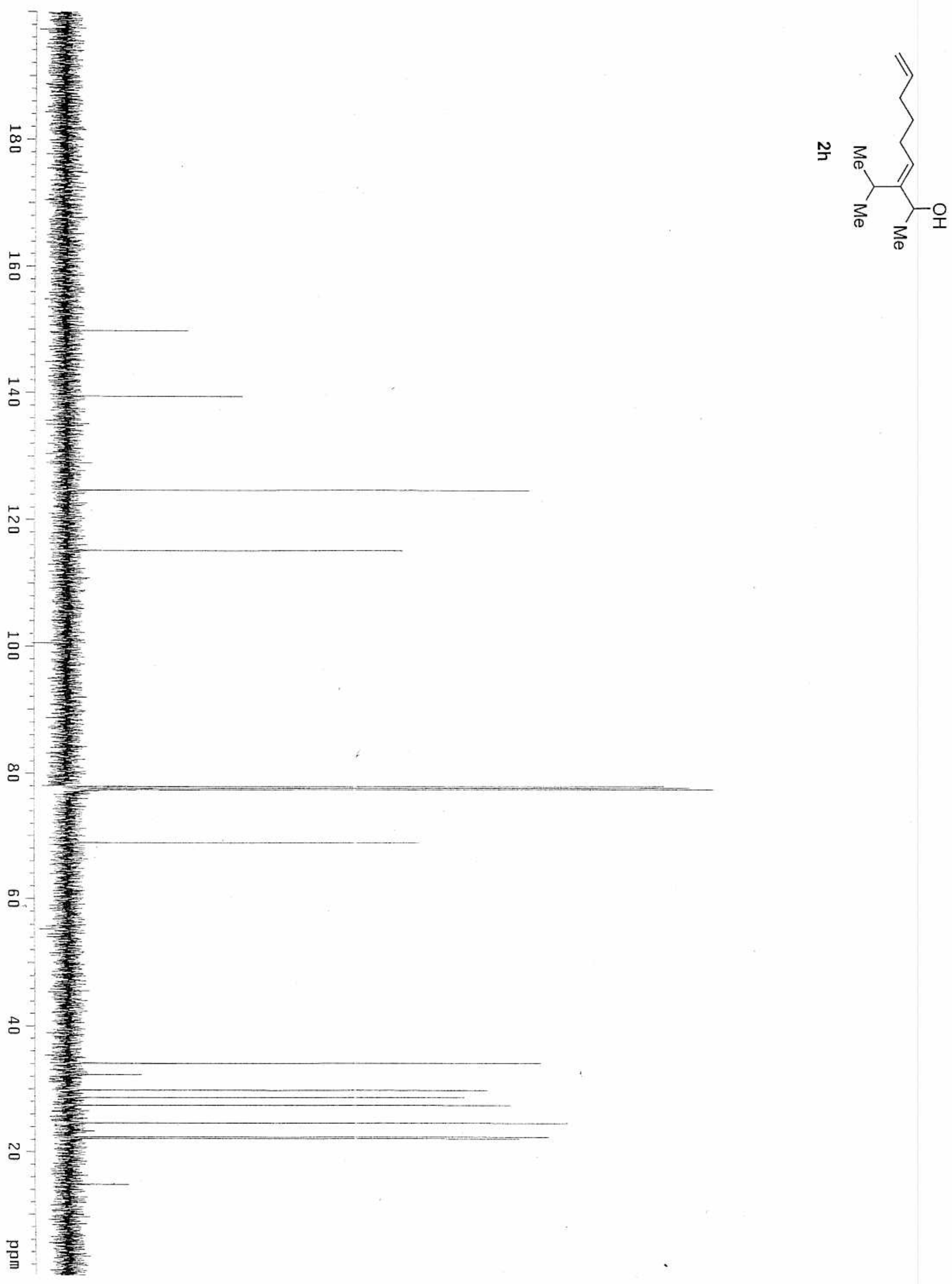


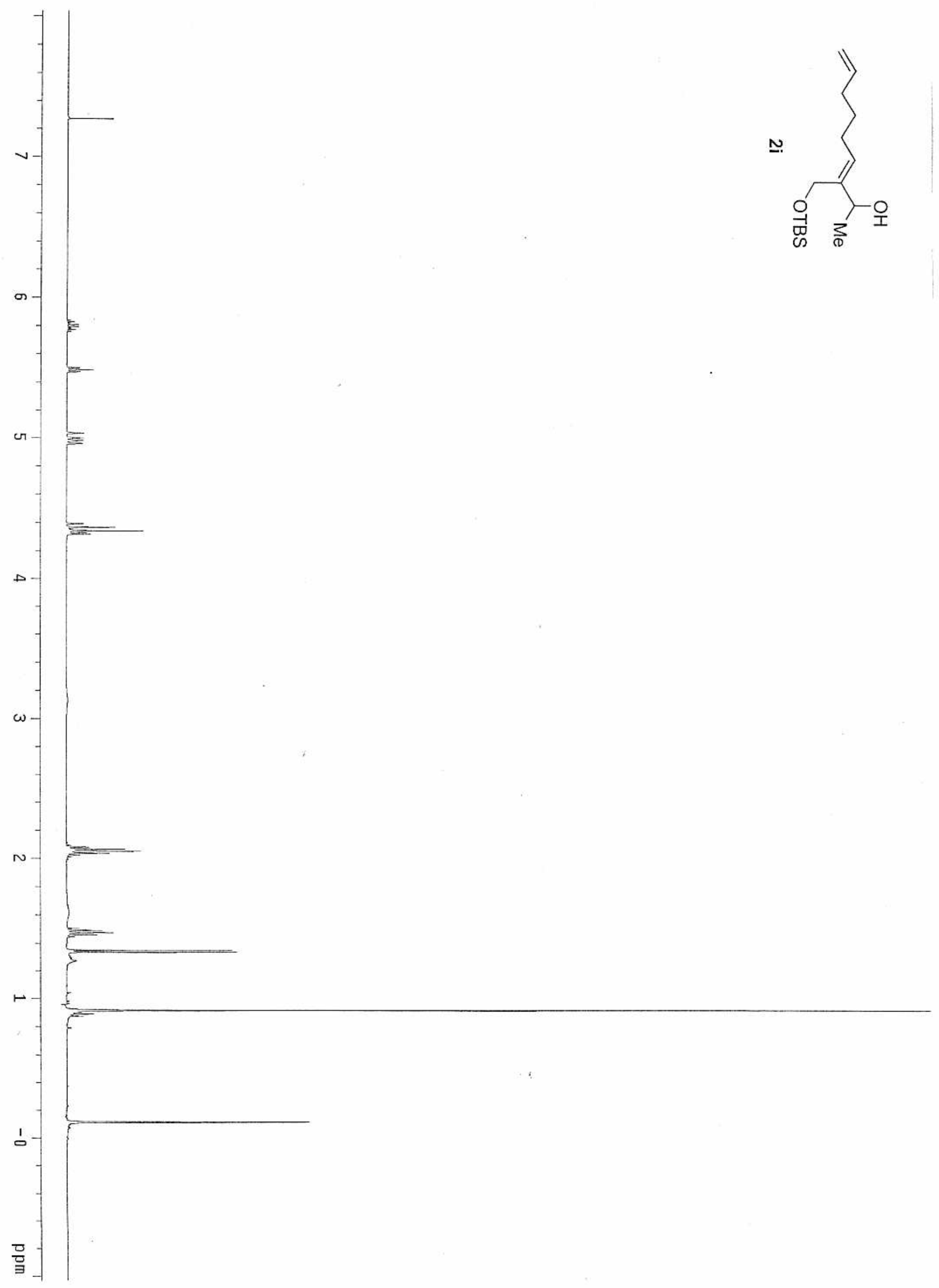




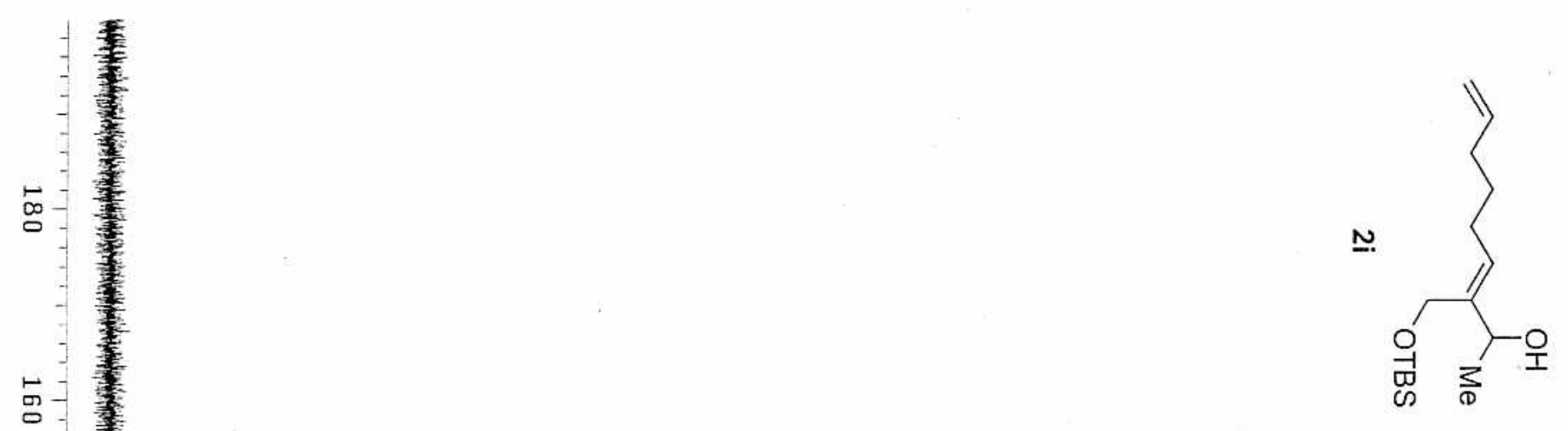




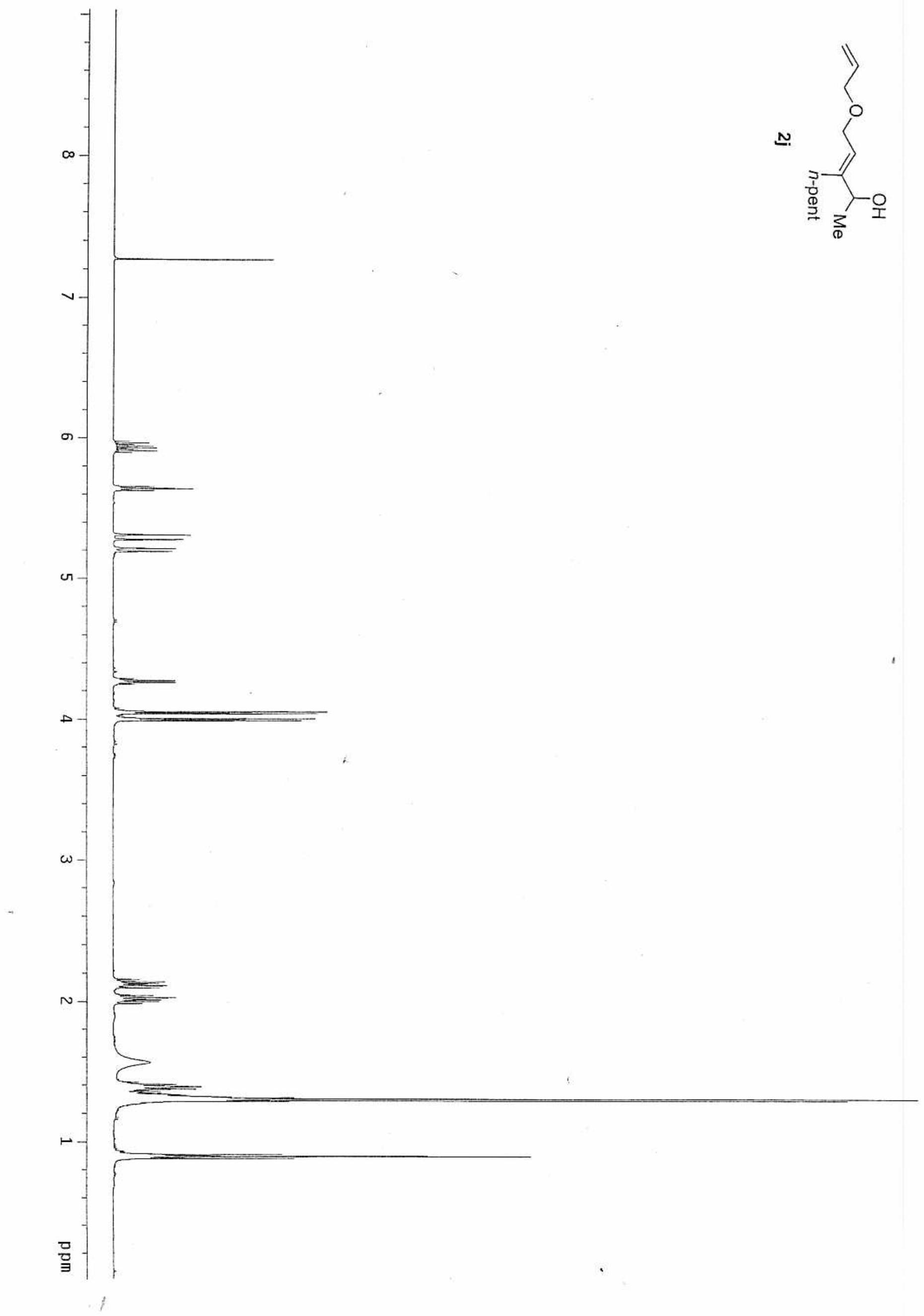




$$
\mid
$$




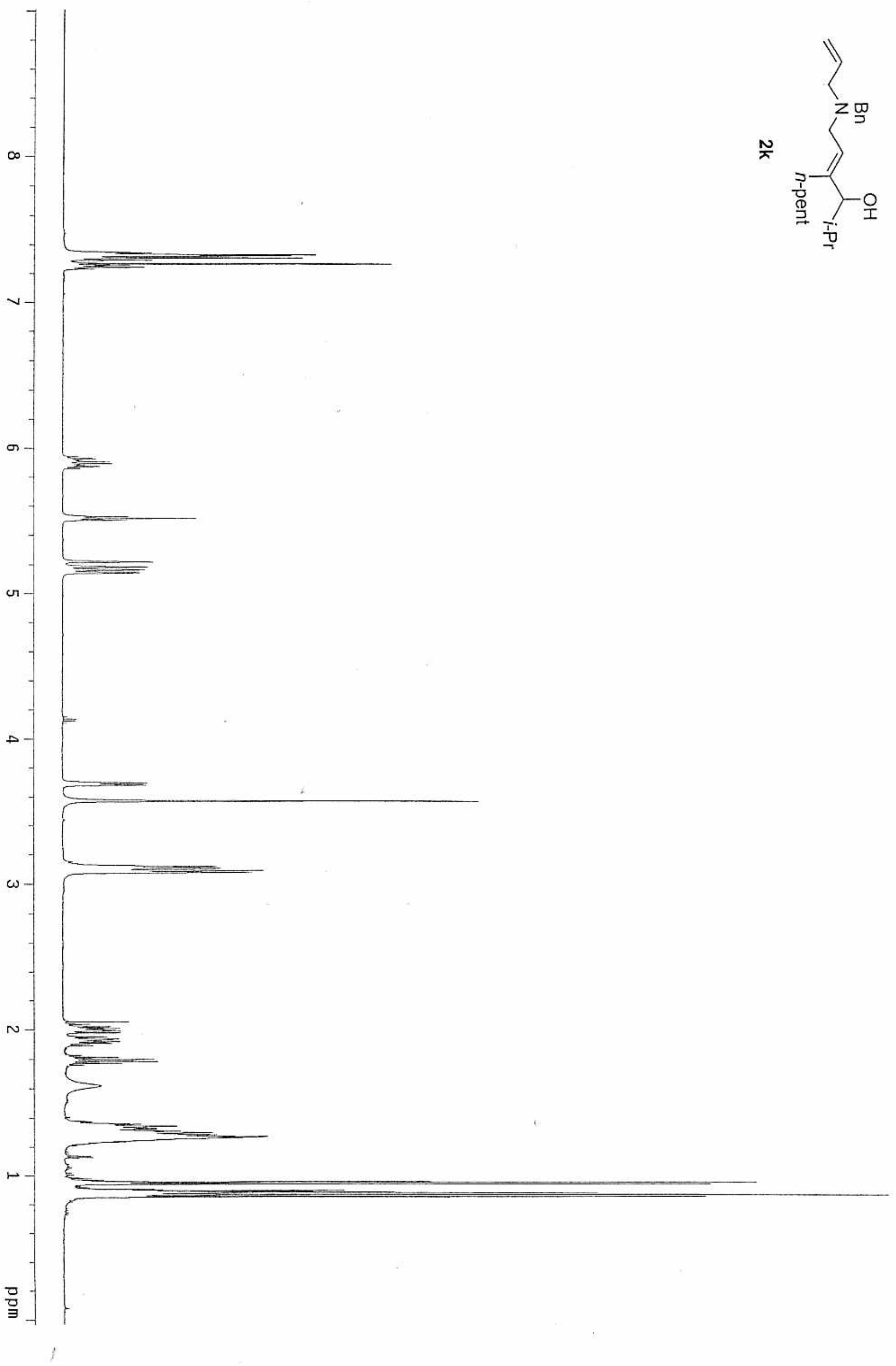




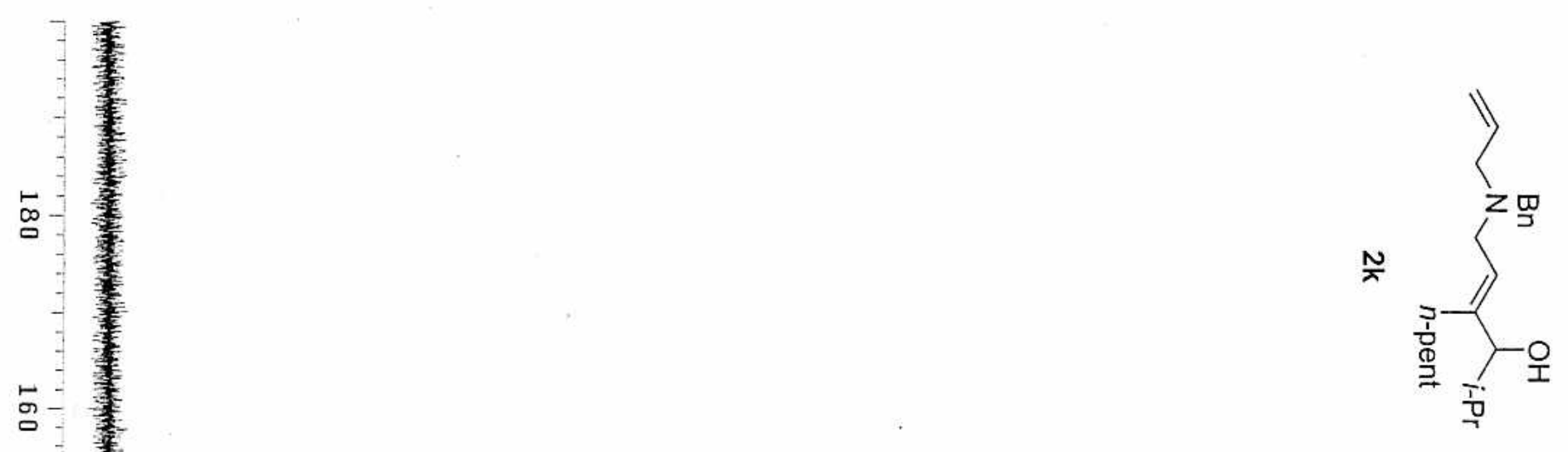




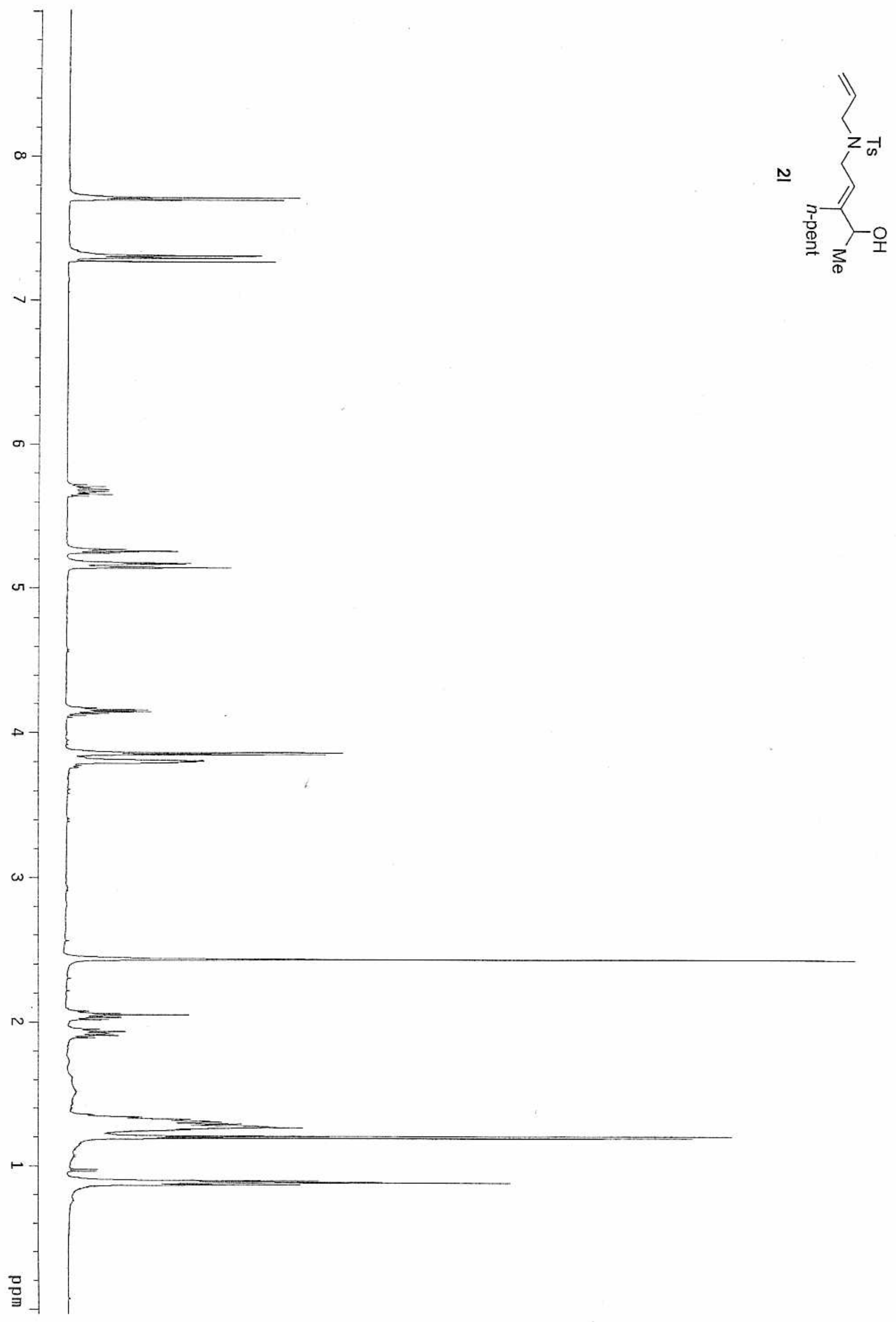




$$
\mid
$$




$$
\begin{aligned}
& E \\
& E
\end{aligned}
$$




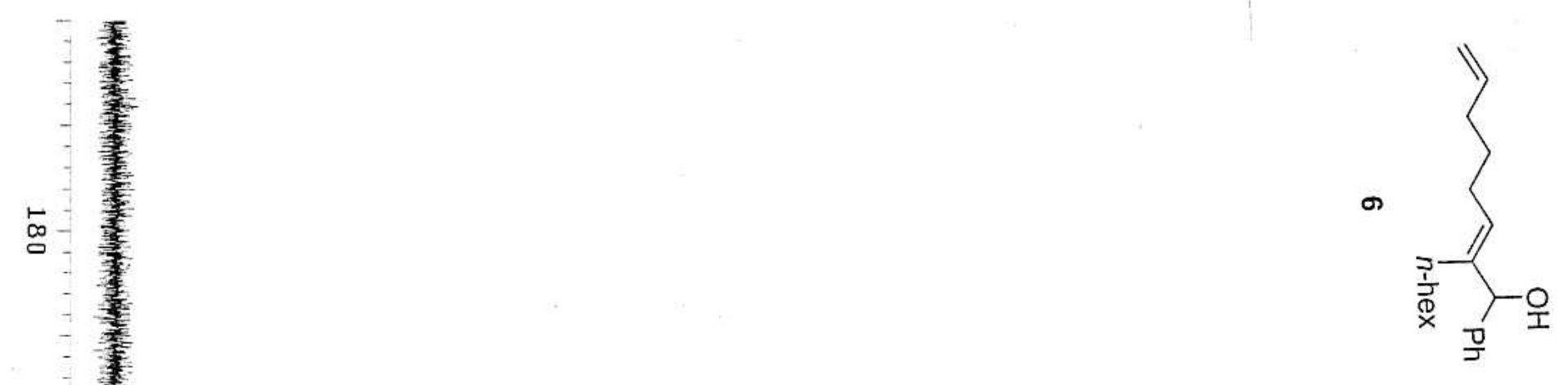




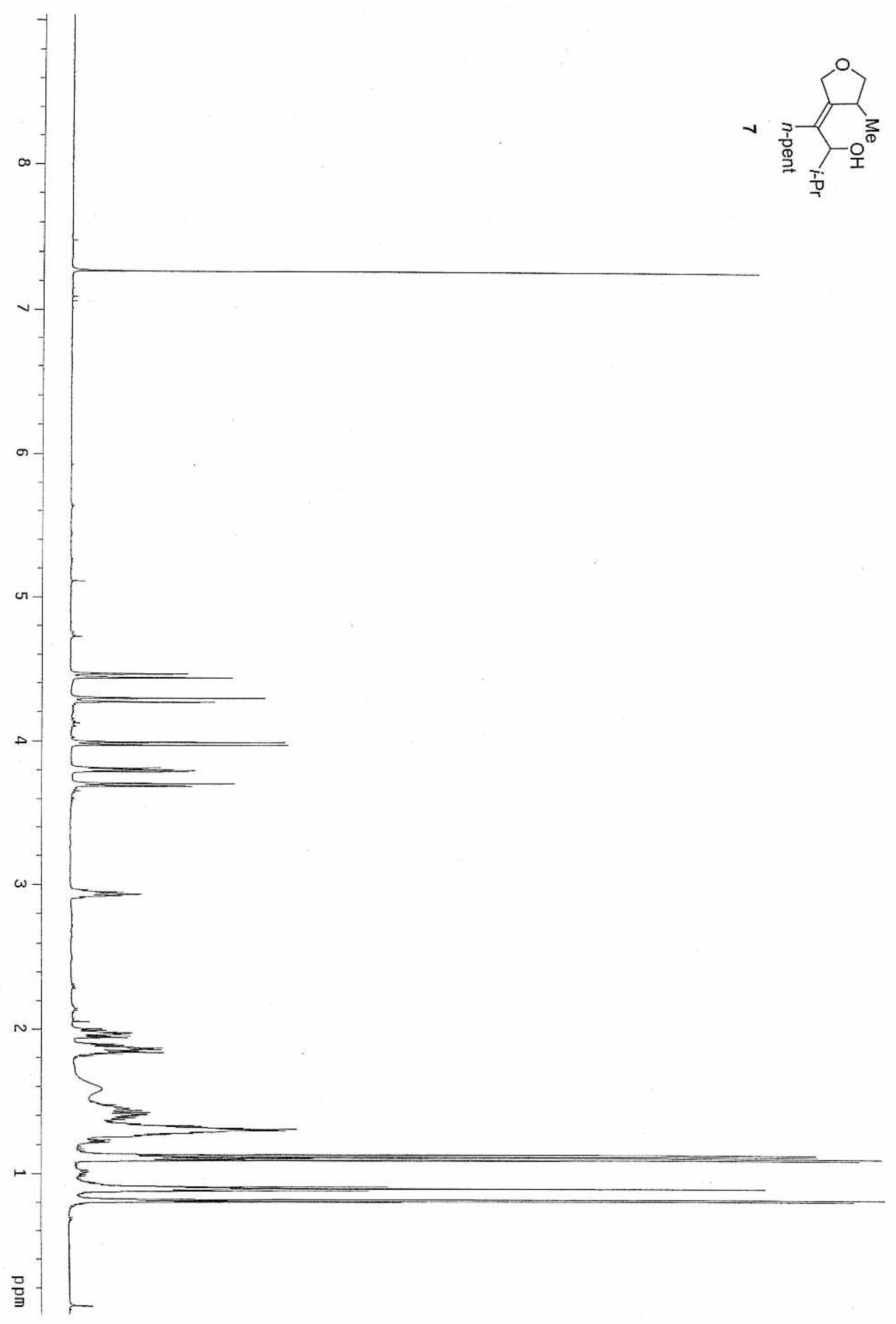




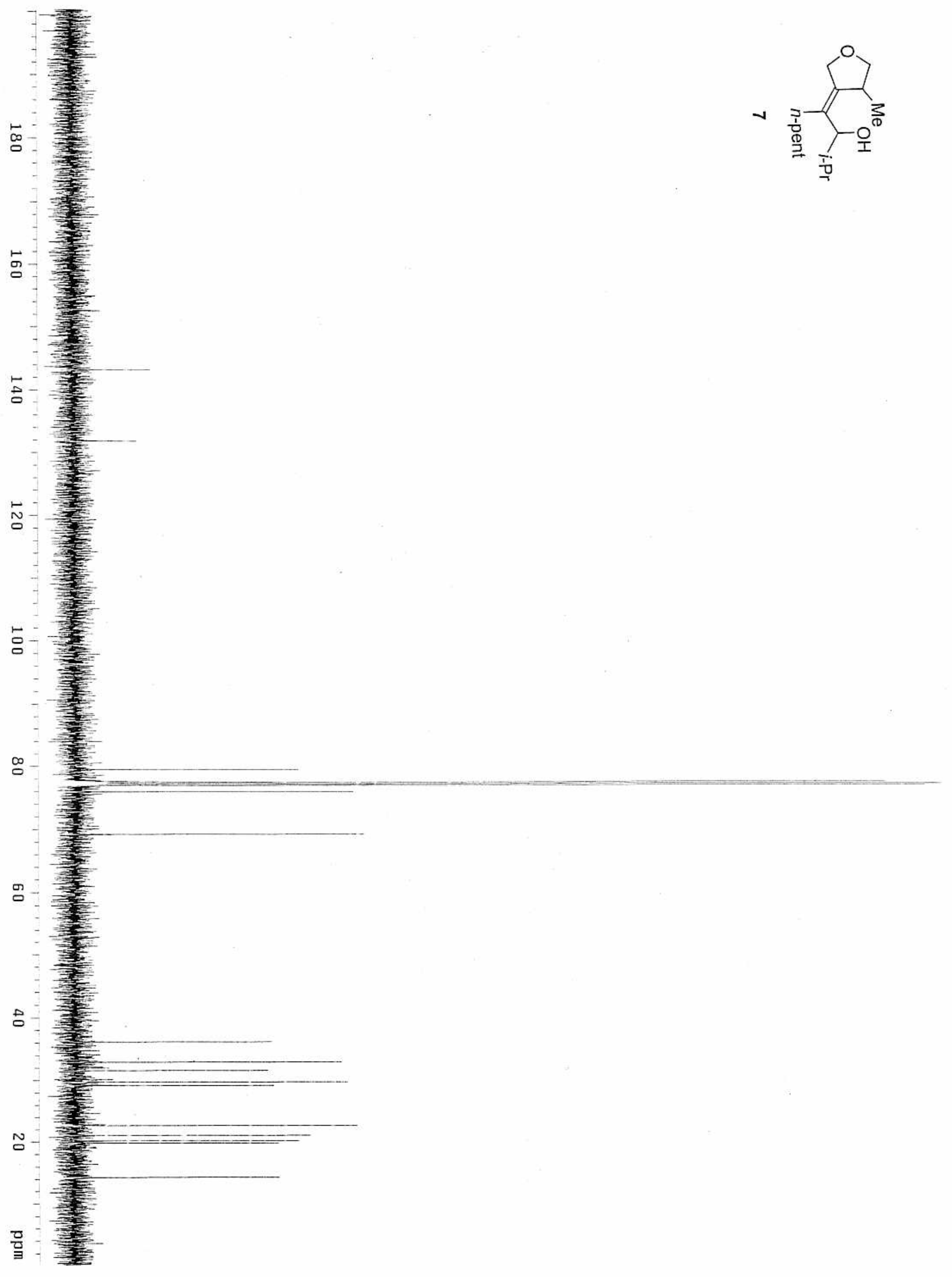




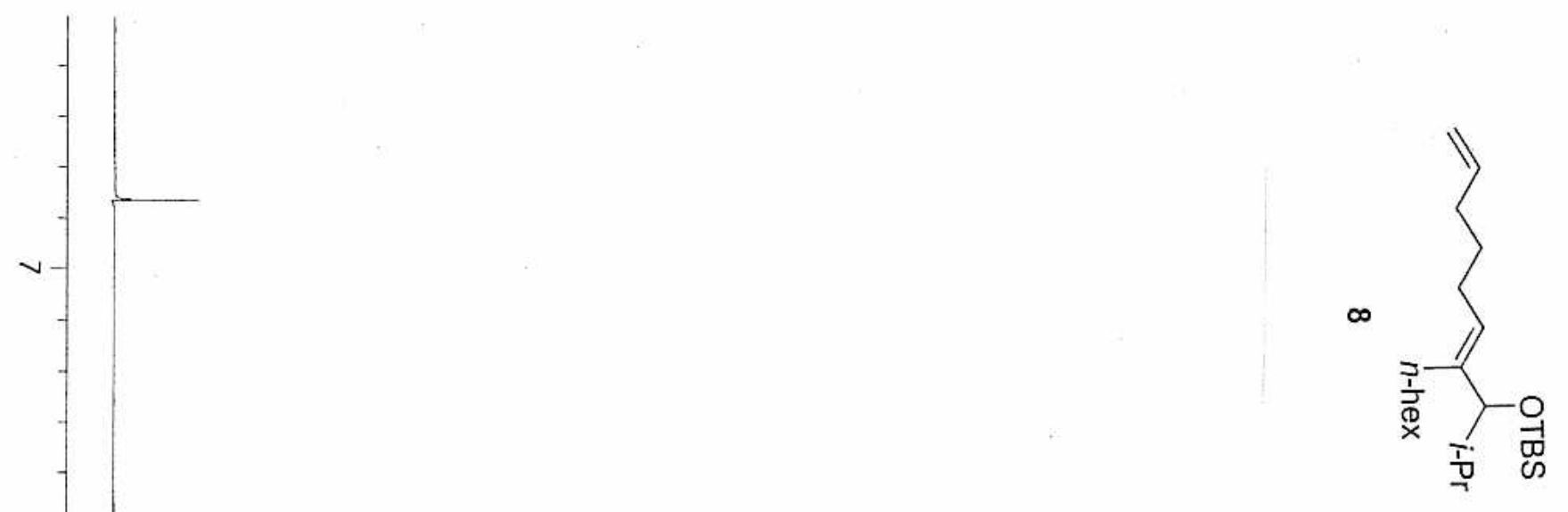




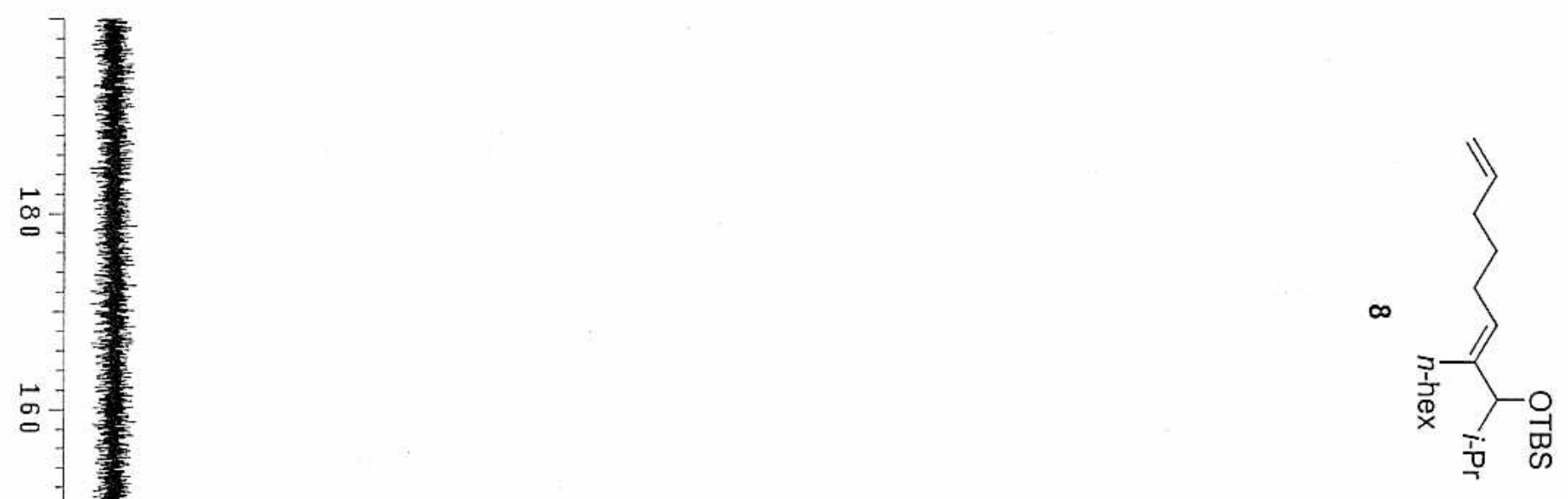




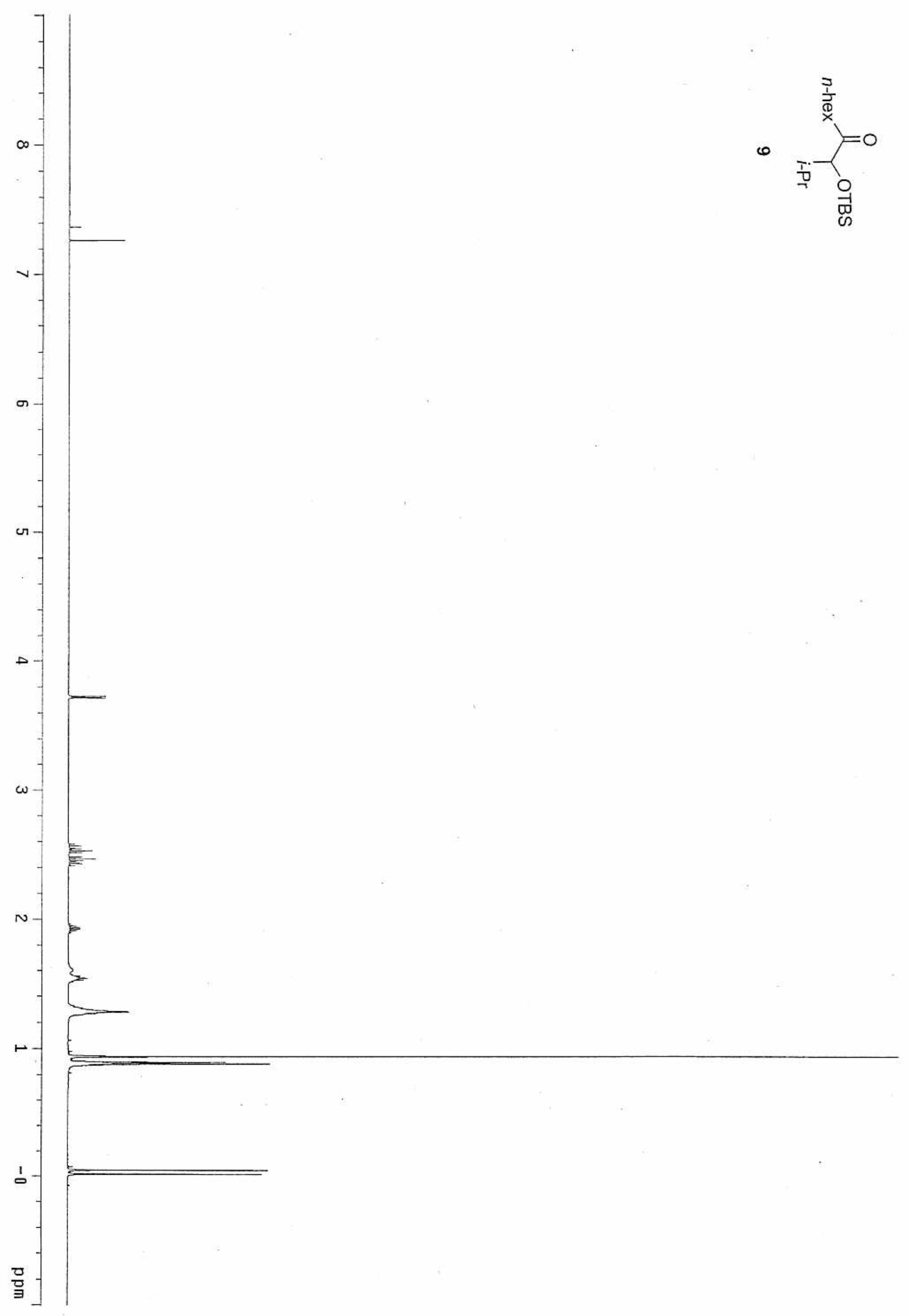




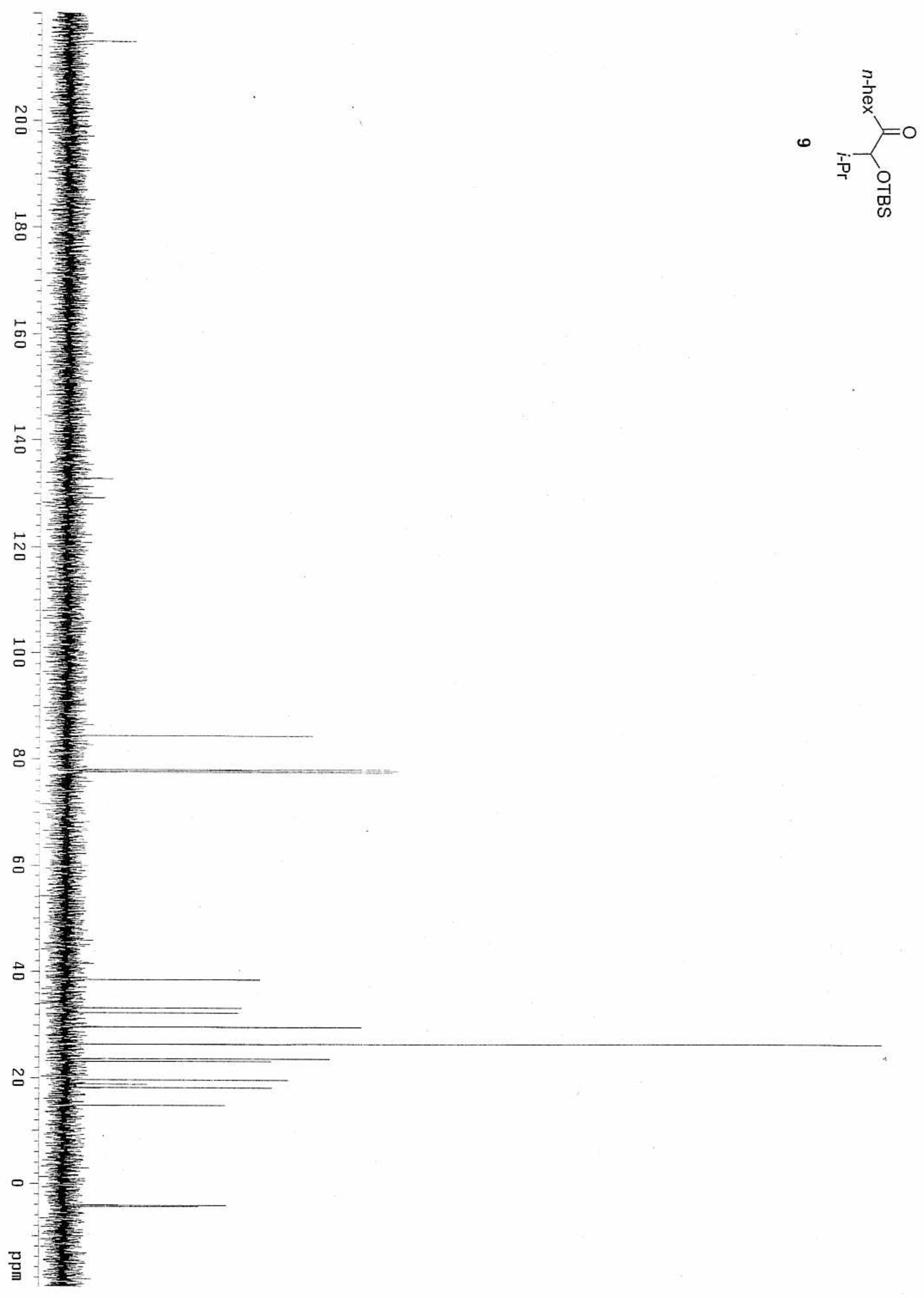




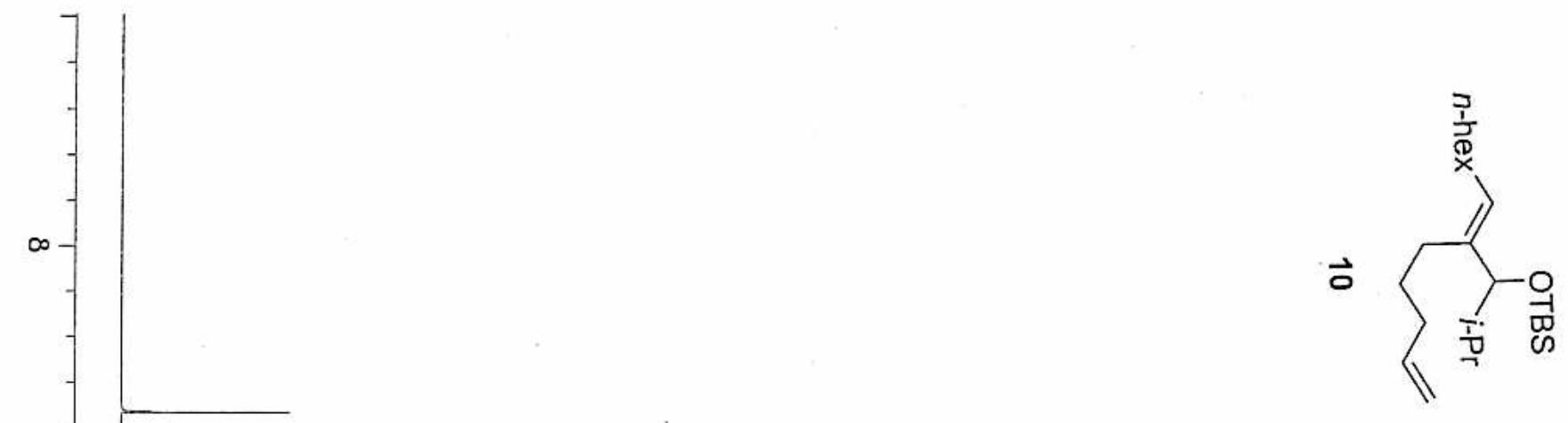




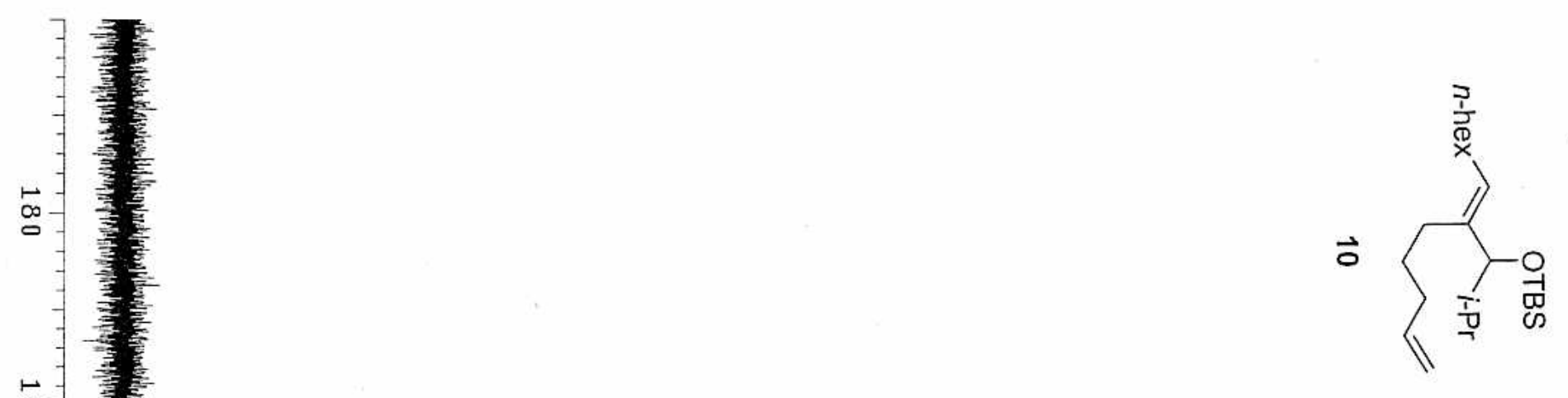




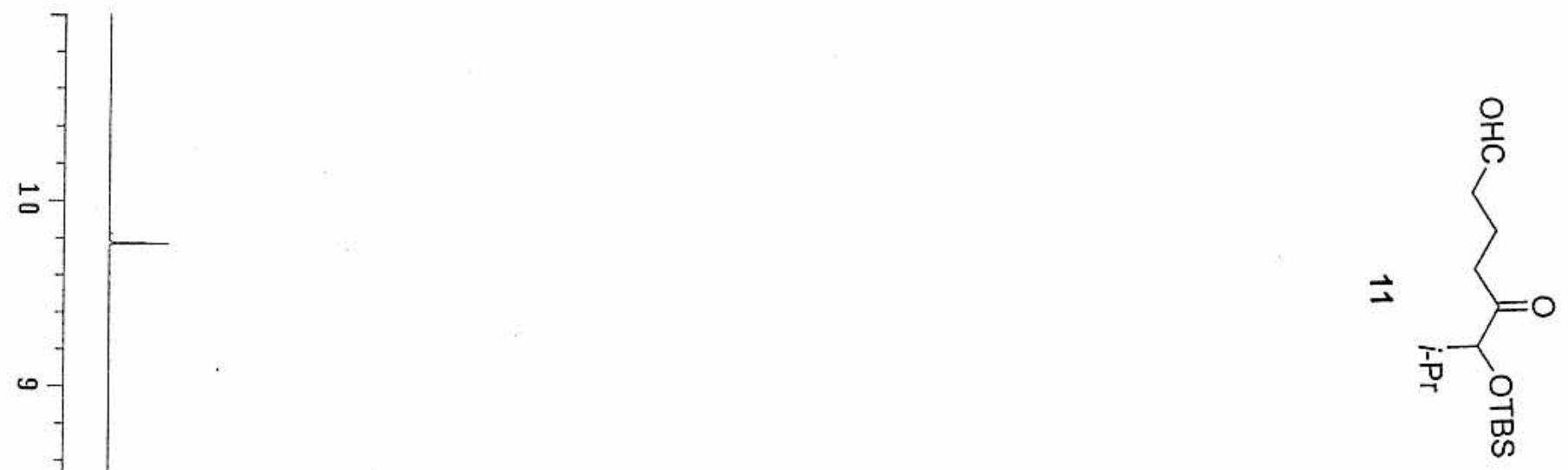




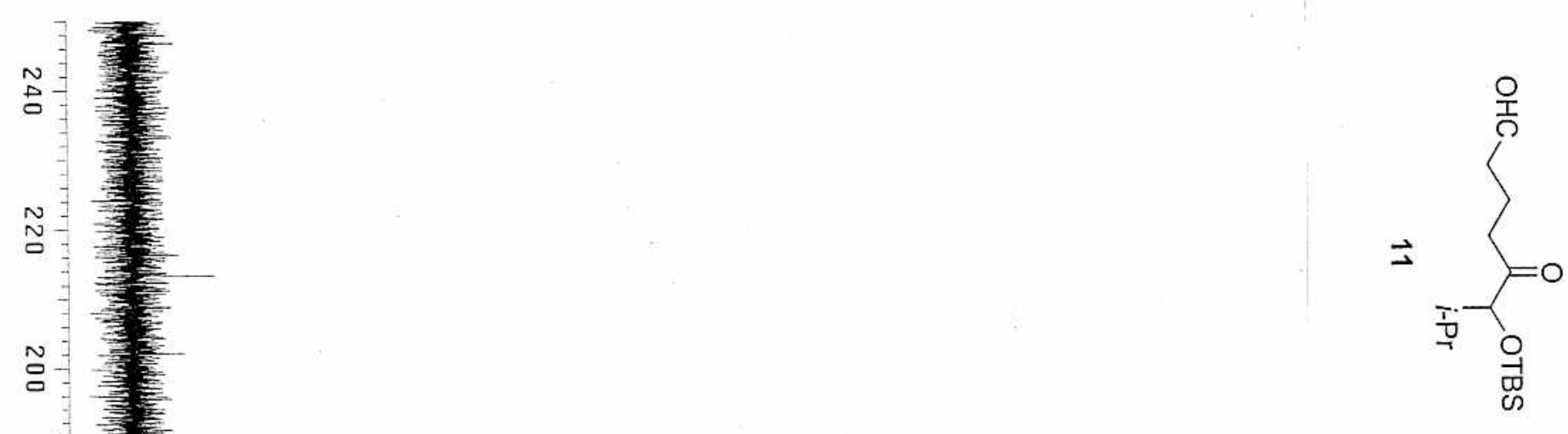

